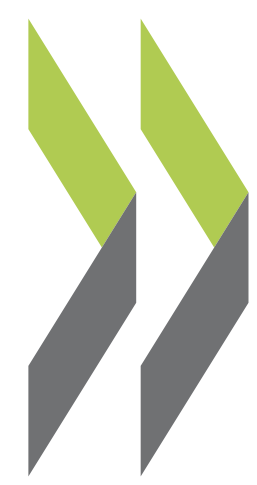

OECD Local Economic and Employment Development (LEED) Papers 2012/04

Skills for Competitiveness: Country Report for Italy

\title{
Sergio Destefanis
}




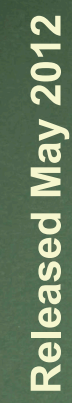

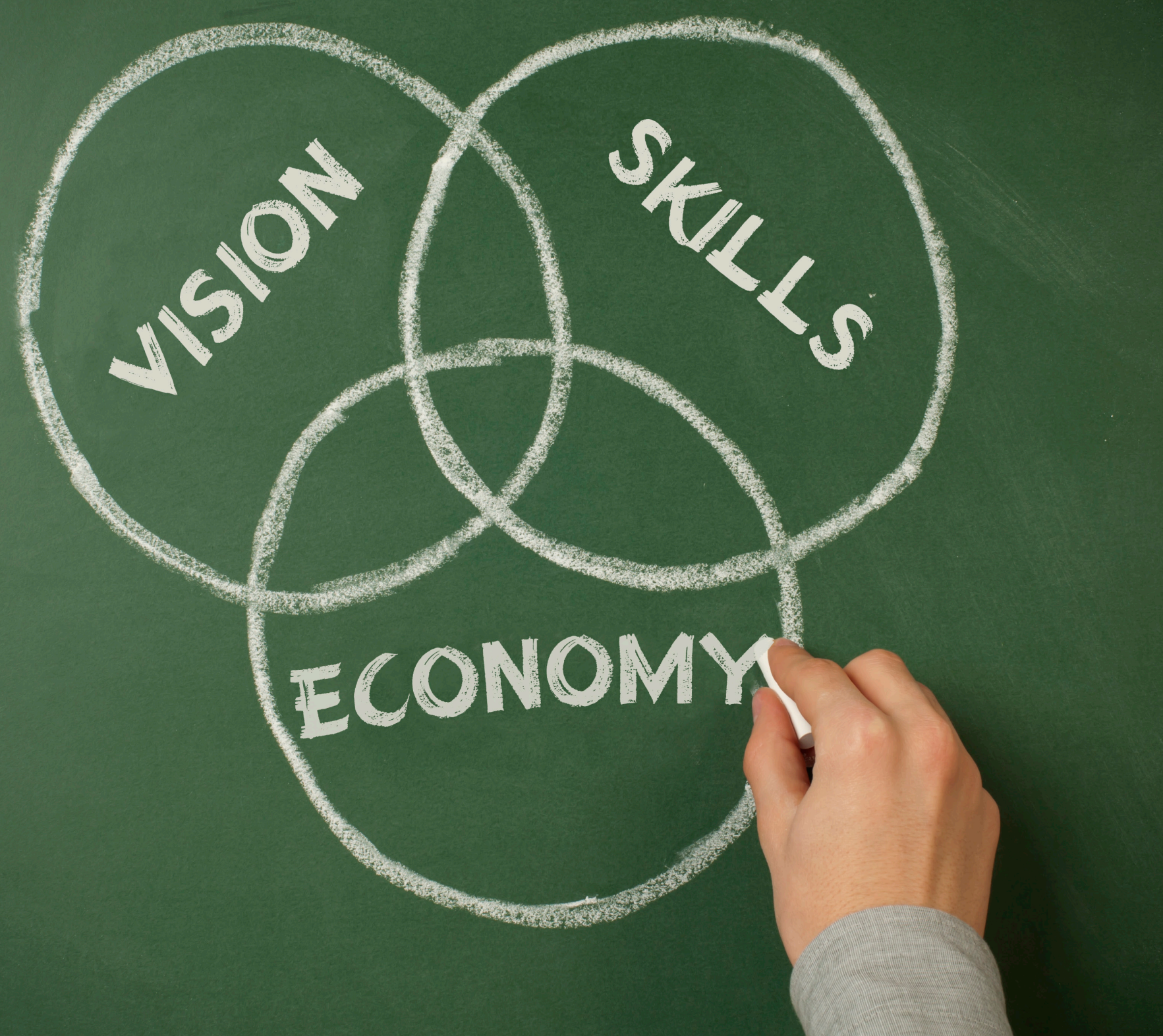

\section{Skills for Competitiveness}

Country Report for Italy

Sergio Desfetanis 


\section{ACKNOWLEDGEMENTS}

The project has been carried out in collaboration with the European Commission and has benefited from the support and active participation of staff from the UK Commission for Employment and Skills, HRSDC Canada, and ISFOL in Italy.

The author and the OECD LEED Programme would like to thank Claudio Tagliaferro, Simona Acunzo, Valeria Iadevaia and Christian Poggi from Area Sistemi Locali e Integrazione delle Politiche, Isfol for their collaboration and invaluable support throughout the project, including assisting with data collection, survey implementation and the policy background. We would also like to thank Chris Warhurst for his very useful comments and analytical inputs, and DG Employment and Social Affairs at the European Commission for supporting this project.

The Author also wishes to thank Nicola Di Matteo, Patrizia Di Monte, Francesca Froy, Mara Manente, Michela Meghnagi, Alfonso Morvillo, Francesco Pecci, Federico Perali, Paolo Sestito for their invaluable support at various stages of the completion of this report. 


\section{TABLE OF CONTENTS}

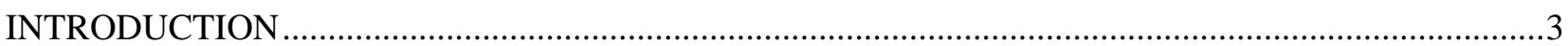

Why is the Skills for Competitiveness project important for Italy? ........................................................

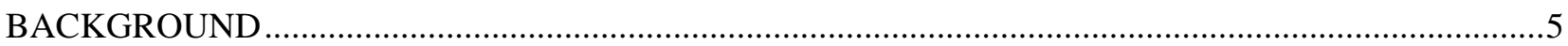

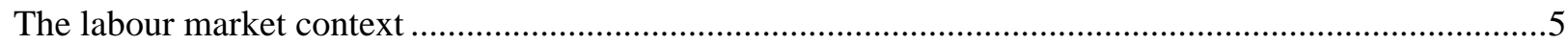

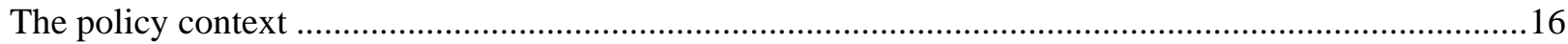

ANALYSING LOCAL DATA ON SKILLS SUPPLY AND DEMAND ................................................25

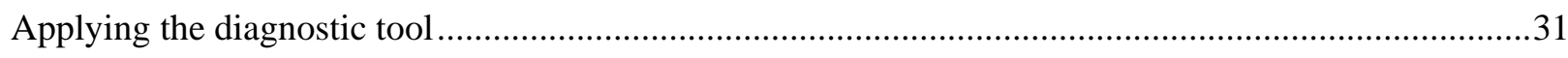

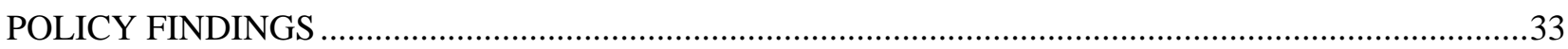

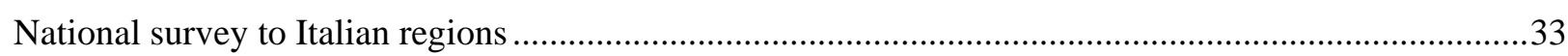

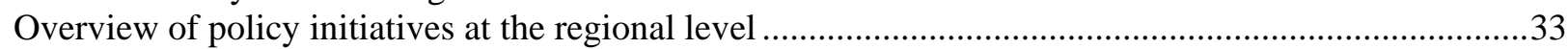

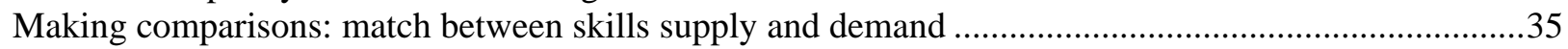

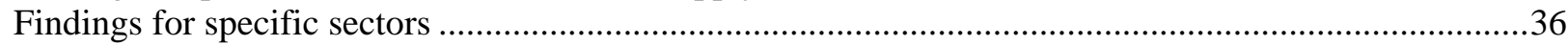

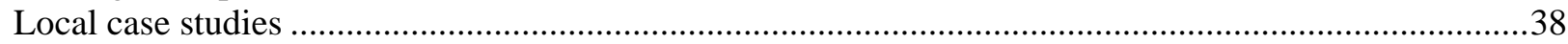

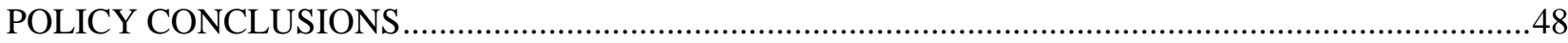

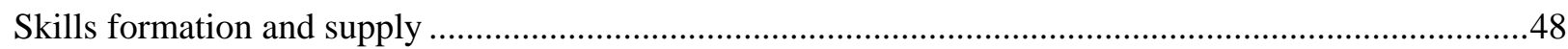

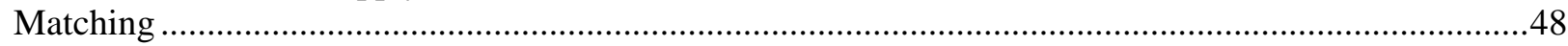

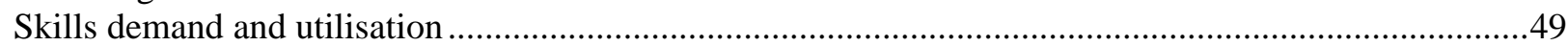

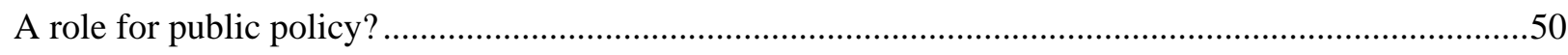

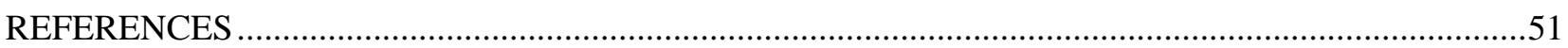

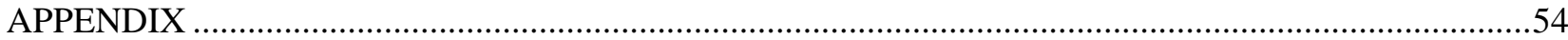




\section{INTRODUCTION}

\section{Why is the Skills for Competitiveness project important for Italy?}

The OECD LEED (Local Economic and Employment Development) programme has developed the international Skills for Competitiveness project, with the aim of providing useful guidance to local administrators in the development of policies directed at raising the level of workforce skills, increasing competitiveness and improving the quality of jobs. To be successful in today's knowledge-based economy, communities need to invest not only in the supply but also in the demand for skills. By stimulating innovation and better utilising the skills of the workforce, communities and businesses can increase productivity and become more competitive. They can also offer jobs, which are better paid and of high quality, fostering career progression within the local labour force.

The OECD LEED programme has begun work on the Skills for Competitiveness project to further examine the advantages of such demand-side policy interventions. The project draws on best practices from across the world through an international literature review, and focuses on policy and practice in LEED member countries, including Canada, the United Kingdom and Italy. It builds on the lessons learned from LEED's work on designing local skills strategies (2009), which showed that balanced skills strategies are important to raising local productivity and increasing socio-economic inclusion at the local level.

The research identified that some local areas, particularly rural ones, are vulnerable to falling into a vicious cycle known as low-skilled equilibrium where a lack of skilled supply is matched by low skills demanded by local employers, who fail to produce quality jobs because they provide low value-added products at low productivity levels. In such areas many qualified young people leave to find better quality employment elsewhere. Those that are left suffer from low incomes and limited career progression, while the lack of productivity limits economic growth at the local level. In such a "low-skills equilibrium trap", skills supply and demand can negatively affect each other therefore policy makers need to operate simultaneously on both sides of the skills equation.

This report will outline the results of implementing the Skills for Competitiveness project in Italy, presenting quantitative findings, identifying best practices and articulating policy lessons. Before presenting the results of the project, it is necessary to give context on the Italian economic and labour market structure highlighting the high proportion of small firms, self-employment and temporary jobs. Moreover, the report identifies that a balance of skills supply and demand is difficult to achieve at the local level because the territorial distribution of various types of assets is uneven. Furthermore, geographic mobility among workers is low and there is a prevalent hidden economy. The report concludes that in order to better balance skills supply and demand, it is particularly important that appropriate job matching policies are put in place. 
The project went through several stages as summarised in Box 1:

\section{Box 1. Project methodology}

Stage 1: International literature review: the OECD LEED Programme commissioned a team of experts from the Workplace Research Centre at the University of Sydney in Australia to undertake an international literature review in order to identify (i) how skills demand and utilisation is being measured at the regional level and (ii) what efforts to improve skills utilisation at the local and regional level have been undertaken in OECD countries in recent times;

Stage 2: Development of statistical diagnostic tool: the LEED Programme developed a statistical diagnostic tool in order to identify the match between skills supply and demand within local labour markets;

Stage 3: Data collection: data on skills levels in the labour force, income levels, productivity, occupational breakdowns, migration, unemployment and utilisation of skills by firms was collected at the sub-regional level (TL3 or Travel-To-Work Areas) in order to implement the diagnostic tool;

Stage 4: Fieldwork in selected areas: fieldwork in Italy included the following activities:

1. A policy background report was drafted by the Institute for the Development of Vocational Training for Workers (ISFOL - Istituto per lo Sviluppo della Formazione Professionale dei Lavoratori) in Italy relating to skills policies both at the national and the regional level;

2. E-questionnaires were circulated to national and regional policy makers and industrial sector bodies to find out more about the obstacles and barriers to effective skills utilisation, and the current policies in place to address these issues.

3. Two regions of interest (Campania and Veneto) were selected. In each of these regions, regional policymakers and experts were interviewed. In addition, an e-questionnaires about skills formation and utilisation was distributed to firms in three industrial sectors (hides and skins; food, beverages and tobacco; and hotels and restaurants).

4. Local case studies were also carried out on collaborative approaches to improving the supply and utilisation of skills at the sub-regional level in the Riviera del Brenta and Treviso in Veneto.

5. An OECD study visit took place in Veneto and included roundtables with local policy makers, national and international experts;

Stage 5: Reporting: The findings from the project in Italy are presented in this report. This includes specific policy recommendations for national and local policy makers. An international synthesis report has also been prepared which is available from the LEED Programme. 


\section{BACKGROUND}

\section{The labour market context}

\section{Changing employment patterns}

In recent years, economic uncertainty has increased in European countries placing pressures on investments in human and physical capital. At the same time fiscal challenges have reduced the resources available for public policies, including training (Cedefop, 2011). Cedefop predicts that over the next decade in Europe the sector of business and other services (including banking and finance) will see slightly slower job growth than previously thought, but will nevertheless generate most new jobs - around six million for the period 2010-20. A significant increase in employment is also expected in the distribution and transport sector (including restaurants and hotels). A more modest increase is projected for nonmarketed services (those often provided at a subsidised cost and delivered mainly by the public sector or non-profit organisations), which could likely bear the brunt of potential public expenditure cuts.

\section{Figure 1. Past and future sectoral employment change (EU 27+), million jobs}

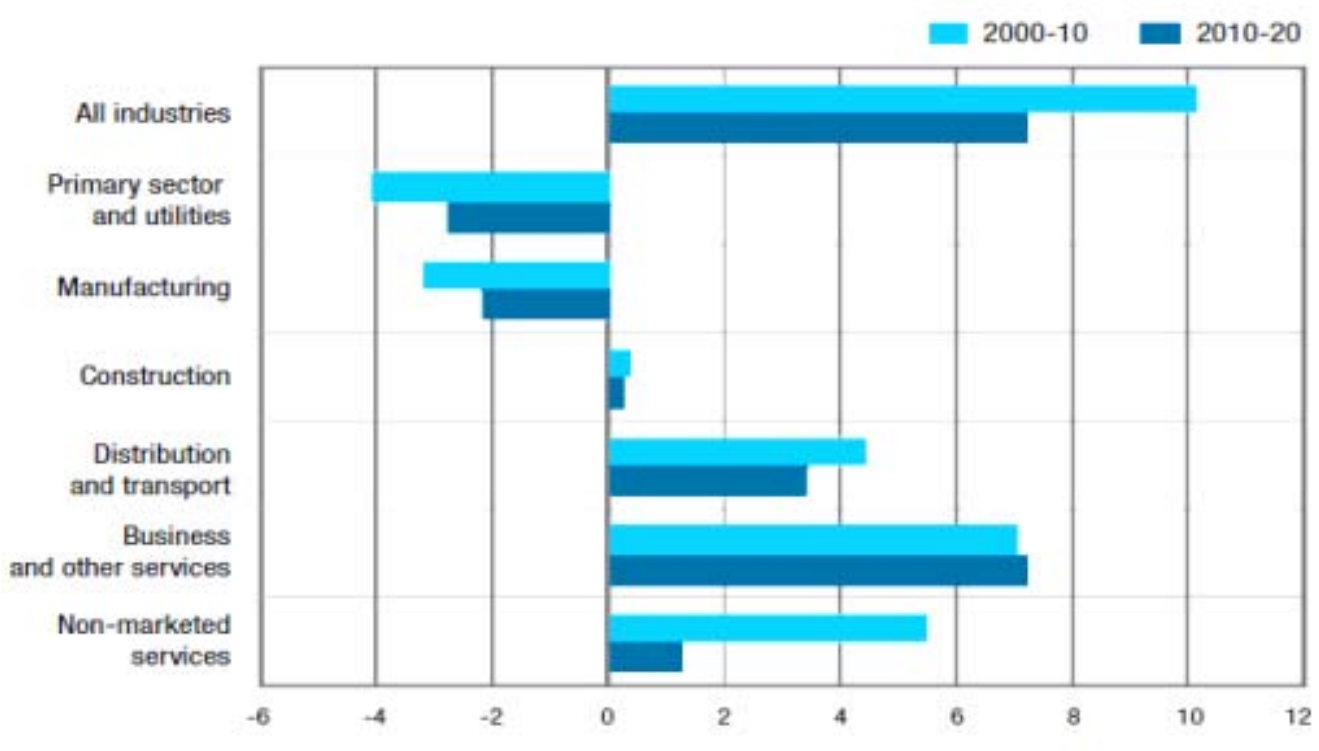

Source: Cedefop (2011)

Naturally if employment patterns are changing within specific sectors, this will impact employment patterns by occupation and qualification levels. Forecasts show that employment will continue to grow in occupations such as management, professional and associate professional jobs (see Figure 2). 
Figure 2. Job openings by occupation group 2010-2020, EU 27+, million jobs

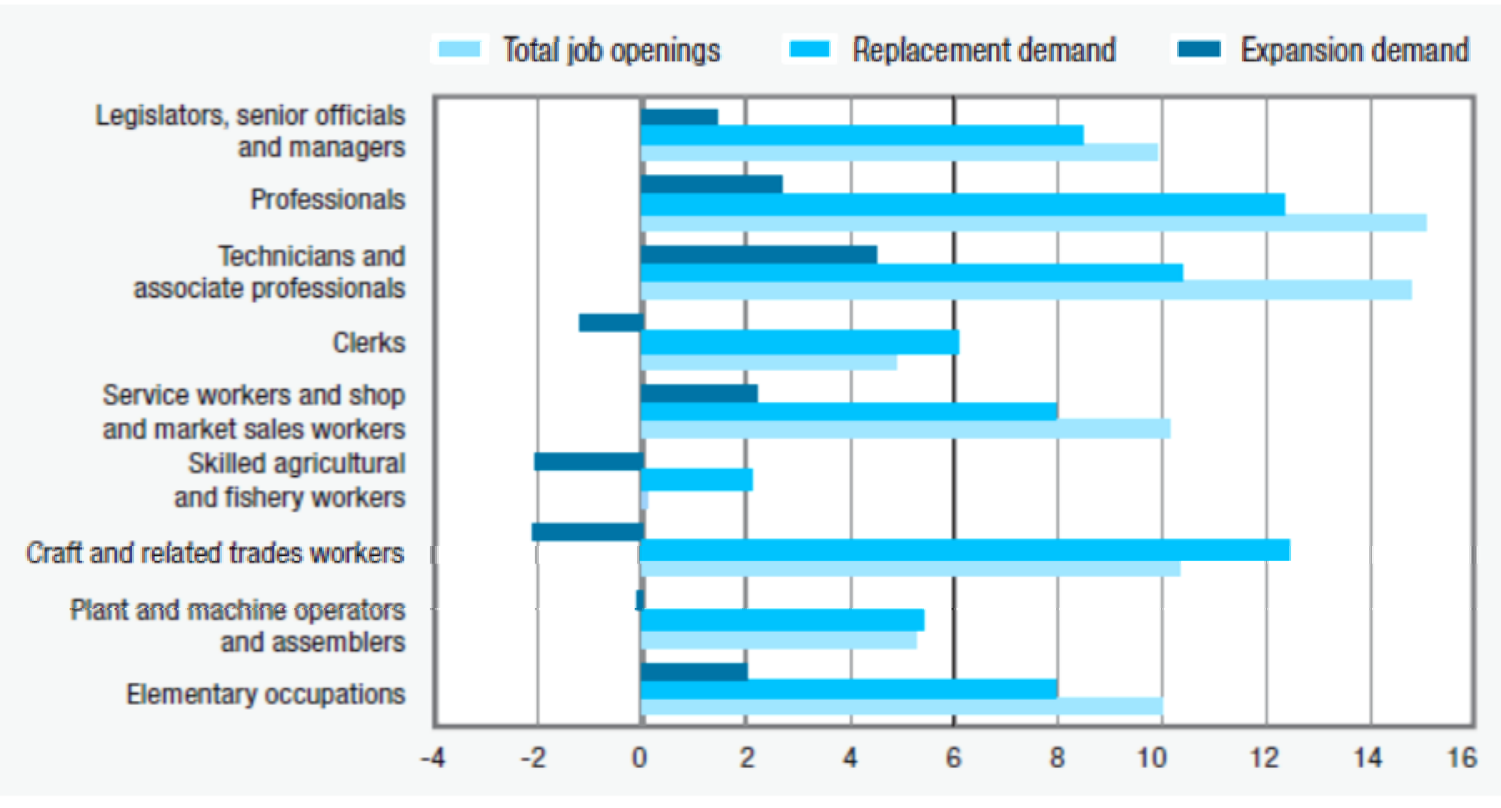

Source: Cedefop(2011)

Future employment patterns will be determined by the evolution of skills supply and demand. Looking at the supply side, a rise in the share of the labour force with medium to high formal qualifications is expected. The largest increase will relate to the proportion of the labour force with the highest qualification levels while the share of the labour force with no or a low formal qualification is expected to decrease between now and 2020 (see Figure 3).

Figure 3. Supply trends in labour force (15+) by qualification, EU $27+$

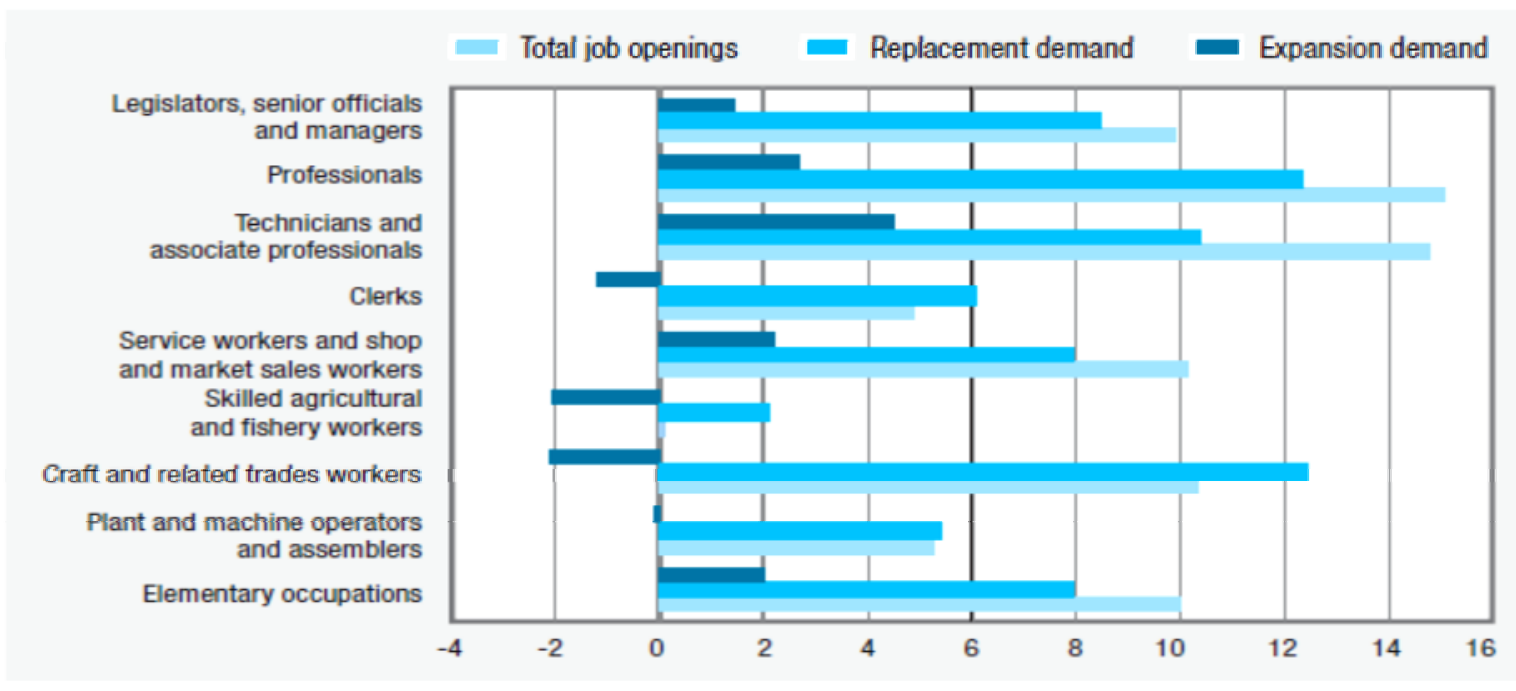

Source: Cedefop (2011) 


\section{Overview of the Italian economy}

Italy currently faces two important economic challenges. The first of these is dualism, which has resulted in a north-south divide in GDP per capita and in labour-market performance. Secondly, since 1992, the economy has been growing at a much slower pace than previously in the post-war period. This slower rate of growth is related to low productivity growth, which can in turn be related to low levels of investment in R\&D and human capital. Additionally, the Italian labour market has been characterised by a high share of self-employment and a significant growth in non-standard jobs in recent years.

\section{Governance and the existence of dualism}

In order to understand local development issues in Italy, it is fundamental to examine territorial disaggregated data both at the local level and across regions. There are twenty bodies at OECD territorial level 2 (TL2) - the regions (regioni) that have legislative authority (see Figure 4).

Figure 4. Italy's territorial structure: the regions

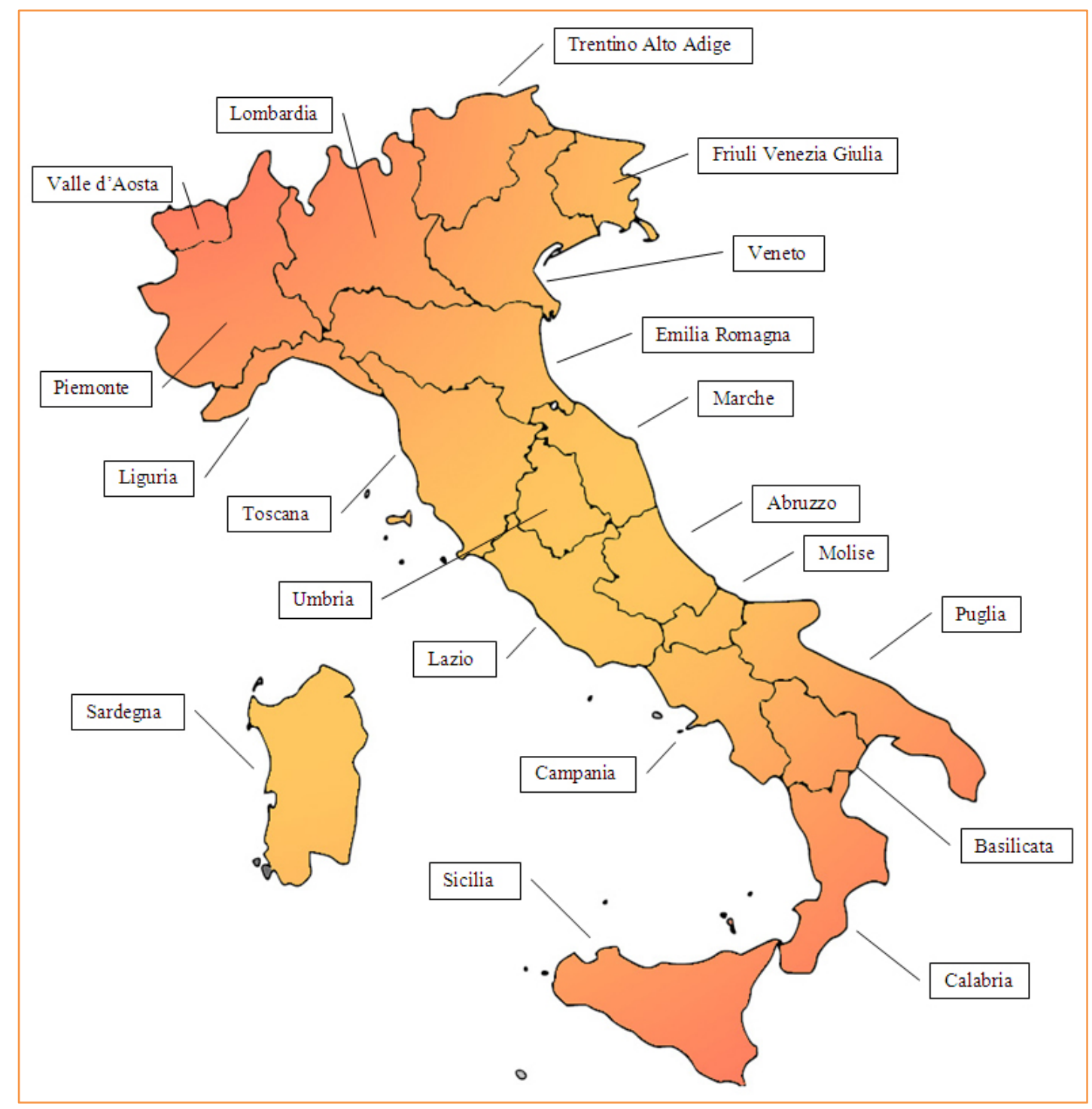


Two further geographical classifications are relevant for the analysis:

- $\quad$ Provinces ${ }^{1}$ (province) which correspond to the TL3 level. These administrative jurisdictions have very little legislative power but there is a reasonable amount of statistical data that allows a reliable assessment of territorial differences in economic performance.

- 686 Local employment systems (Sistemi locali del lavoro, SLL) identified by the Italian Statistical Office (ISTAT). This classification (akin to the UK's Travel-to-Work-Area) groups a number of municipalities adjacent to each other geographically and characterised by common commuting patterns. In order to investigate the socio-economic structure of local labour markets at a disaggregated territorial level, this classification represents the best available approximation. Recent research (ISTAT, 2006) has highlighted differences in economic performance across the Italian territory. Unfortunately, statistical information at this level of disaggregation often cannot be obtained therefore the analysis in this paper is carried out at the OECD TL3 level.

Dualism means that there are substantial proportions of the population living in areas of the country that are considerably poorer than the national average. This inequality between regions is far more serious in Italy than in other countries with similar levels of income per capita (Iuzzolino, 2009: see also OECD, 2005a). When looking at 27 OECD countries, Italy is ranked seventh in terms of territorial inequality (measured through a Theil index on TL2 areas), with a level of inequality two thirds above the median and almost twice as large as that found in most countries with similar GDP per capita (e.g. Spain, Germany, Japan or the United Kingdom). In contrast to other countries, the level of inequality is not influenced by the presence of a single region with a higher level of income, often coinciding with the capital city. (Iuzzolino, 2009, Table 2).

More generally, the presence of inequality does not change even when using a more detailed territorial classification (TL3 or local employment systems, SLL) to understand the possible presence of sub-regional areas with relatively high income levels. Figure 5 below, depicts the GDP per capita of the SLL's in 2005, clearly identifying strong economic differences across Italy. The GDP per capita gap is related to the structure of the Italian labour market. There is a difference of almost 27 percentage points in the activity rate of the working age population between the south and north-centre regions (Iuzzolino, 2009). Differences across regions are less than five points on average in other European countries.

\footnotetext{
${ }^{1}$ The number of provinces has recently proliferated in Italy and they are now 110. In 2001 they were 103 provinces and this is the partition used in our analysis.
} 
Figure 5. The Italian local employment systems (Sistemi locali del lavoro)

GDP per capita in thousands EUR, 2005

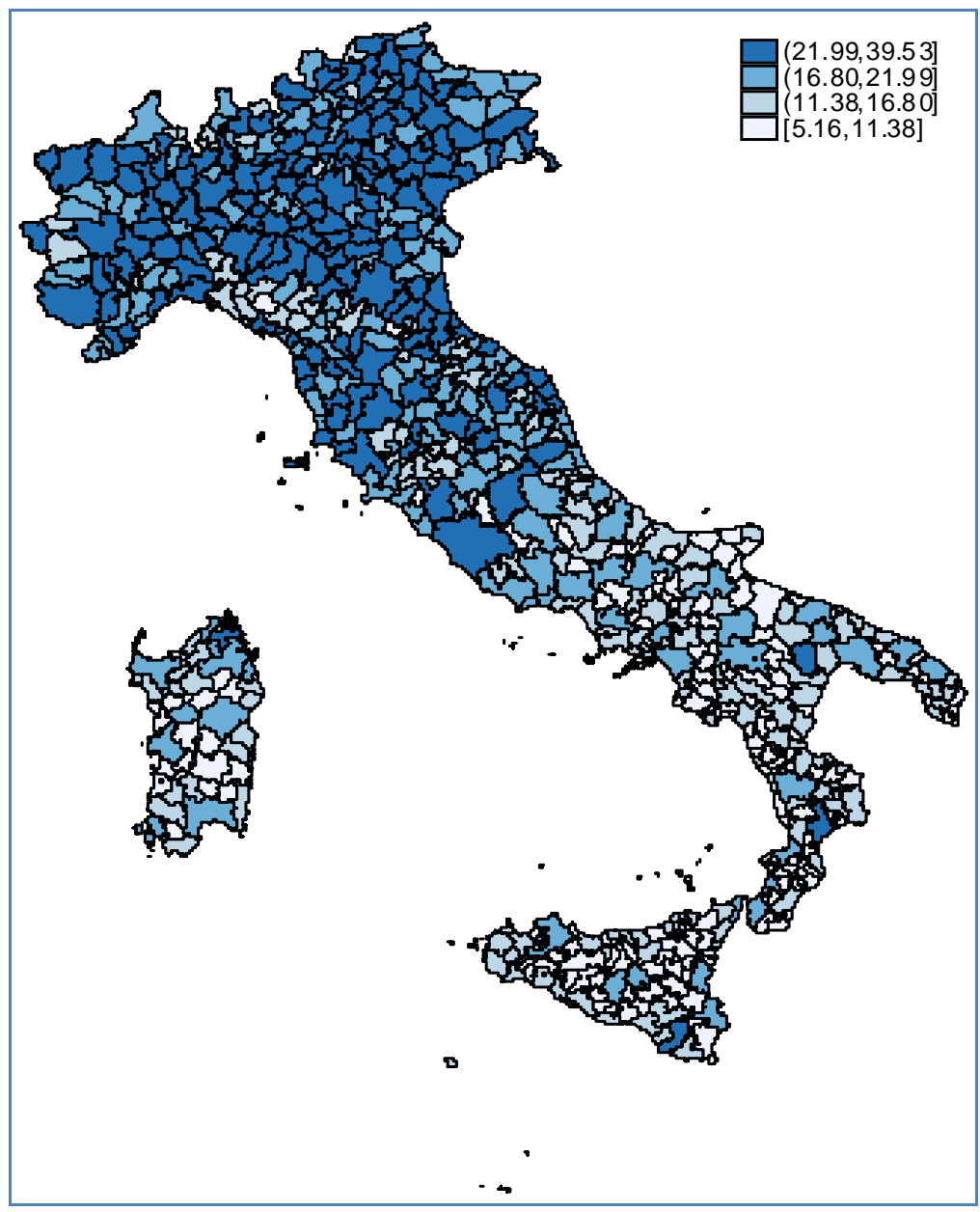

Source: Own calculations based on ISTAT (2006)

Another challenge is the presence of a large hidden economy. As shown in Table 1 below, it is prominent in the agricultural sector in all regions but it is unevenly distributed across other sectors. In 2008, regions in the south were characterised by the highest proportion of irregular workers across all sectors. In comparison to other areas, the percentage difference is notable especially in the manufacturing and construction sectors. 
Table 1. Irregular units of labour by sector and geography (as \% of total labour units), 2008

\begin{tabular}{|l|l|l|l|l|}
\hline & \multicolumn{1}{|c|}{ Agriculture } & \multicolumn{1}{c|}{ Manufacturing } & \multicolumn{1}{c|}{ Construction } & Services \\
\hline North west & 24,8 & 1,9 & 6,9 & 12,1 \\
\hline North east & 24,7 & 1,7 & 3,0 & 11,3 \\
\hline Centre & 21,8 & 3,2 & 7,8 & 11,3 \\
\hline South & 25,0 & 12,9 & 18,6 & 18,4 \\
\hline Italy & 24,5 & 4,0 & 9,8 & 13,5 \\
\hline
\end{tabular}

Source: Istat, 2006

\section{Productivity and innovation}

Since World War II, the development of many advanced countries, including Italy, has been influenced by improvements in the production of material goods and the absorption of existing technologies. The growth of income and education has encouraged a shift towards a knowledge-based economy, which has resulted in the growth of the service sector. Between 1980 and 2000, the share of the services sector in EU countries increased by 13 percentage points (up to 70\%). At the same time, information and communications technology (ICT) has been gradually implemented in both the industrial and services sectors, which has led to the outsourcing of mass production to countries with a sufficiently educated labour force and relatively low labour costs.

For advanced countries, this means that an increase in innovation is required. A good measure of innovation is the number of international patents and, on this, European economies have failed to keep pace with the United States. Similarly, another important component of innovation is the intensity and nature of research and development (R\&D). Several scholars have argued that the traditional model of R\&D which was centralised in large labs has been replaced by a model in which R\&D is carried out in a decentralised manner by universities and businesses. Thus, it is critical that there is a strong connection between them (Furman et al., 2002).

Looking at innovation within the EU, Finland and Sweden have shares of R\&D expenditure (total and funded by business) higher than the U.S., while the Mediterranean countries generally have very low expenditures. Over the past decade, spending on R\&D in Italy - as a share of GDP - has remained essentially stable at slightly above $1 \%$. However, expenditures are mainly oriented towards the public sector (including universities) and less towards businesses.

Italy's employer base is made of medium-sized and, above all, small firms. Interesting results emerge when comparing Italy to the five largest European economies (Italy, France, Germany, UK and Spain). The number of firms in Italy relative to the other four countries is the highest (32\%), followed by Spain and France (around 20\%). In terms of the number of employees, including those who are self-employed, Italy's proportion is 18\%, which is slightly higher than in Spain (16.0\%) and France (17.7\%). This result reflects the relative higher number of small firms in Italy. At the same time, Italy's percentage of value-added (15.0\%) is only higher than that of Spain (12.1\%). Collectively, Germany and the United Kingdom represent just $27.7 \%$ of the number of firms, employ just under half of employees (48.1\%) but produce more than half of the value added (53.8\%) - see Table 2. 
Table 2. Number of firms, number of employees and value added in selected countries - 2004 (\% of the total for each dimension)

\begin{tabular}{|l|l|l|l|l|l|l|}
\hline & \multicolumn{1}{|c|}{ Italy } & \multicolumn{1}{c|}{ France } & Germany & UK & Spain & Total \\
\hline N. firms & 32.1 & 19.1 & 14.6 & 13.1 & 21.1 & 100 \\
\hline N. employees & 18.2 & 17.7 & 25.7 & 22.4 & 16 & 100 \\
\hline Value added & 15.0 & 19.0 & 28.3 & 25.5 & 12.1 & 100 \\
\hline
\end{tabular}

Source: Istat, 2006

These cross-country comparisons show that productivity levels and growth seem to be positively correlated with the average firm size (Pagano and Schivardi; 2003). Hence there are obvious challenges for Italy's competitiveness, which have been primarily addressed through the implementation of a dense network of industrial districts (distretti). This term refers to businesses that are closely related to each other - especially through subcontracting relationships and "specialisation by stages", operating in a particular sector, in close proximity to each other, characterised by communal links (see Box 2).

\section{Box 2. The industrial districts}

Industrial districts are agglomerations of firms, generally small and medium, located in a limited geographical area and specialising in one or more phases of a production process and integrated through economic and social relations. Today, Italian law recognizes and protects about 200 districts, distributed throughout the country. Their local proximity allows rapid movement of ideas and easy interaction between individuals/ firms which are part of the same district. This exchange includes the sharing of technical and production knowledge, conveyed also through specific channels of training, which spreads the values and interests of the district as well as an entrepreneurial culture. The formation of the districts has mainly involved industrial sectors characterised by:

- Intensive production processes and low levels of automation

- $\quad$ Limited fixed capital (investment and equipment);

- $\quad$ Lack of economies of scale in the production process;

- Innovation linked to processes of "learning by doing".

These features can be found in the production of durable consumer goods for the home (furniture, ceramics), people (glasses, jewelry, and clothing) and equipment used to produce them. The production process in the industrial districts is split between different companies which achieve the benefits of specialisation (efficiencies and economies of scale). Simultaneously, the dense network of relationships across firms ensures adaptability to processes of volume (elasticity) and product differentiation (flexibility), necessary to adapt rapidly to changes in demand.

Relations between firms are based on cooperation between actors operating at different levels of the production system and competition among those who perform the same activities. Section 1 in the Appendix presents the distribution of distretti and proposes three different measures: (i) ISTAT, (ii) S. Paolo research institute, and (iii) the weight of distretti-based exports over total provincial exports.

Source : Becattini, 2004 
A high number of firms in Italy are family businesses or consist of individuals who are self-employed. In 2004, one in three workers in Italy were self-employed, while in Spain the ratio was half in comparison. In France the ratio of self-employment was one in 20 workers. In Italy, it is almost $50 \%$ of total employment when looking at the trade sector (see Table 3). These features (i.e. the higher prevalence of small firms and number of individuals who are self-employed) are a fundamental aspect of the Italian economy (e.g. Rossi, 2006). Furthermore, Italian family businesses often have a closed ownership and informal corporate governance structure bound by ties of kinship and non-transparent agreements.

Table 3. Self-employment in major European countries by economic activity, 2004 (\%))

\begin{tabular}{|l|l|l|l|l|l|}
\hline & \multicolumn{1}{|c|}{ Italy } & France & Germany & UK & Spain \\
\hline Mining & 12.3 & 0.6 & 1.1 & 1.4 & 3.3 \\
\hline Manufacturing & 16.6 & 2.2 & 2.2 & 3.4 & 5.5 \\
\hline Energy & 2.5 & 0.1 & 0 & 0.3 & 3.1 \\
\hline Construction & 40.7 & 11.7 & 12 & 14.9 & 17.2 \\
\hline Trade & 49 & 6.2 & 11.1 & 7.1 & 22.7 \\
\hline Hotels and restaurants & 40.9 & 10.6 & 17.5 & 6.9 & 24.9 \\
\hline Transport and communication & 17.2 & 3.2 & 5.2 & 4.2 & 20.4 \\
\hline Business services (a) & 43.8 & 4 & 13.9 & 10.8 & 19.3 \\
\hline Total & $\mathbf{3 3 . 2}$ & $\mathbf{5 . 1}$ & $\mathbf{8 . 3}$ & $\mathbf{7 . 6}$ & $\mathbf{1 7 . 4}$ \\
\hline
\end{tabular}

Note: (a) FIRE, research, other business services.

Source: Istat, 2006

All of these factors have impacted the productivity of the Italian economy. In the 1980s, Italy saw very rapid growth in labour productivity in manufacturing due to fast capital accumulation (about $3 \%$ per year). In contrast, there has been a notable decline in the growth rate over the last two decades. This change applies to all sectors (although with a slightly different time lag). A cross country comparison of changes in labour productivity are presented in Figure 6. 
Figure 6. Hourly Labour Productivity - 2006 -1996 change

(vis-à-vis a mean EU15 index = 100)

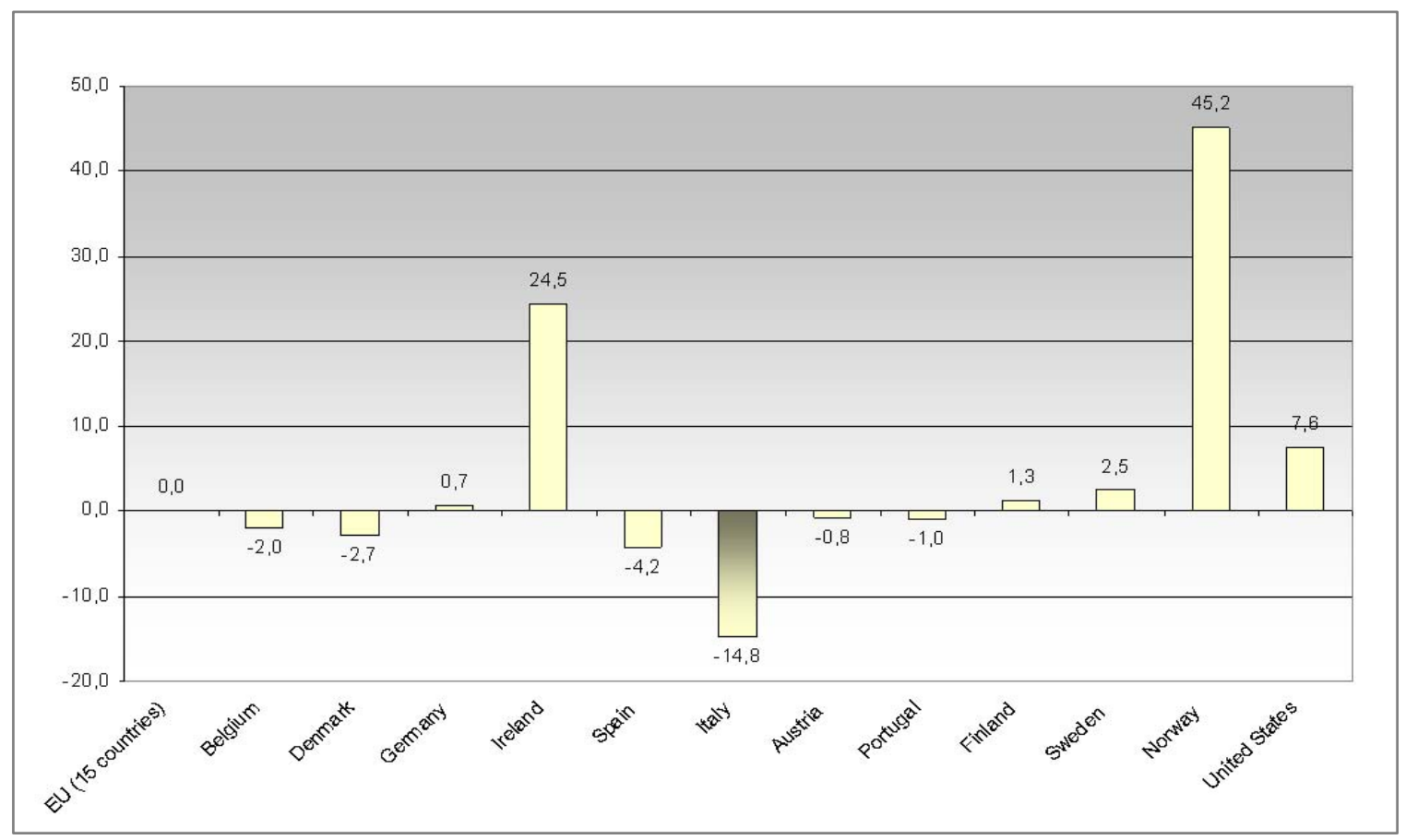

Source: Istat, 2006

\section{Sectoral reallocation}

The prevalence of self-employment, low levels of technology adoption and innovation have negative consequences not only for job quality and for the types of occupations but also for the structure of the Italian economy. Most countries have seen a reallocation of labour from low-productivity sectors, such as agriculture to high-productivity sectors, such as services. In comparison to other major European countries, the Italian economy is still "under-tertiarised", which means that Italy has a lower percentage of employment in the services sector (Daveri and Jona-Lasinio, 2005).

\section{Developing human capital}

The lower capacity of the Italian economy to innovate is connected to the quantity and quality of human capital. One of the main challenges is the lack of on-the-job training. Ederer (2006) measures average Human Capital Endowment per capita (HCE) by calculating the level of investment in five different dimensions of skills formation:

- Informal parental education: general skills and cultural adaptation that parents teach their children;

- Formal school education: general skills which children learn mostly in primary and secondary school;

- Formal university and higher education: specific skills that students learn in university and vocational training institutions; 
- Formal and informal adult education: skills which adults acquire outside of their daily work environment, which are nevertheless either directly or indirectly job-related such as management training;

- Informal learning on the job: skills acquired incidentally as part of daily job activity and as a result of adaptation to new requirements on the job.

Figure 7 illustrates HCE levels by country. Italy is ranked fourth from the bottom and its HCE is about $60 \%$ less than Sweden's (who is first on this indicator).

Figure 7. Human Capital Endowment per capita by country

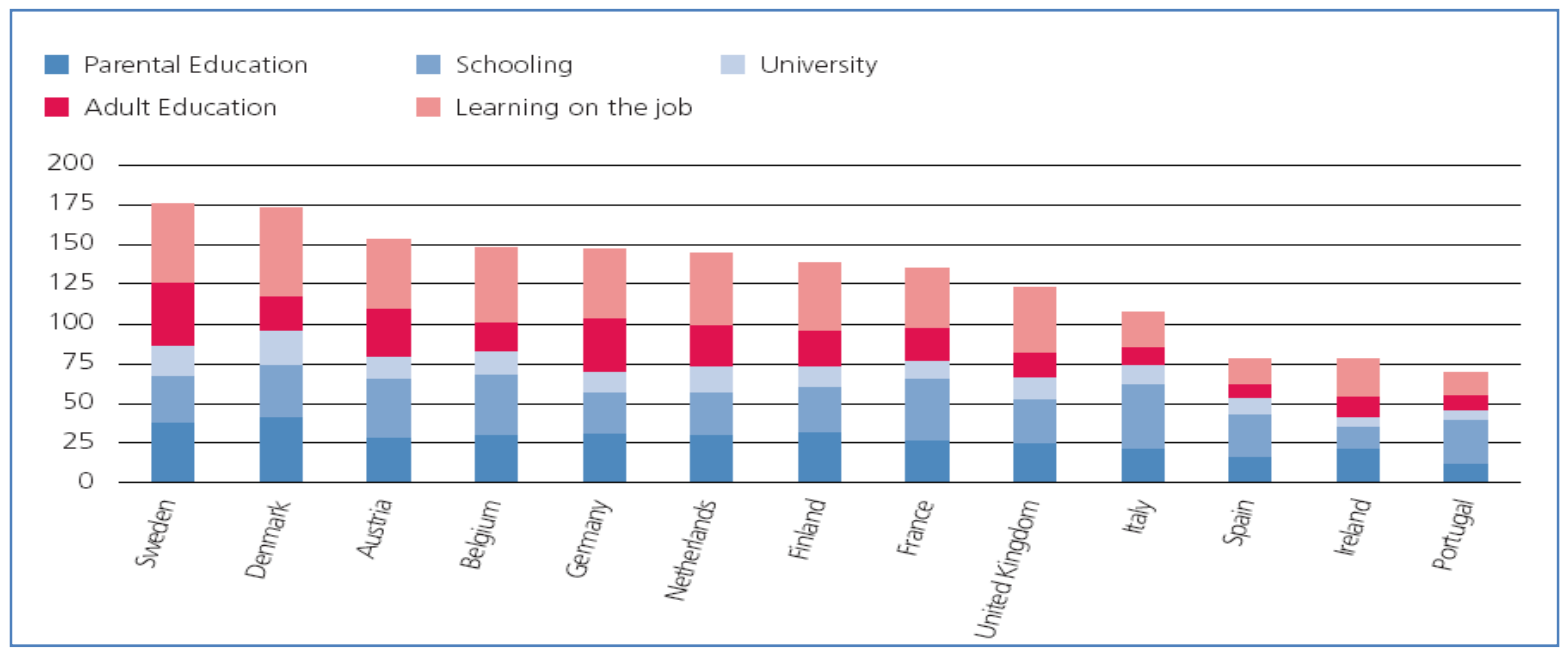

Source: Ederer (2006)

According to Ederer (2006), countries with a particularly high HCE are more likely to invest in fostering adult education and learning on the job. High HCE also contributes to the likelihood that the labour force receives skills training to incorporate new technologies and foster innovation into their work environment. In contrast, low investment in adult education leads to poor utilisation of new technologies. This is particularly relevant for Italy, where investments in human capital are relatively lower in university (a growing strategic segment of the innovation system of a country) than in primary and secondary education. $^{2}$

A number of studies examine the efficiency of investment in human capital in terms of the quality of education. An example is given in Figure 8 which shows the relationship between investment (per student) in secondary education and the OECD PISA scores (Afonso and Aubyn, 2005).

\footnotetext{
${ }^{2}$ OECD data tells a very similar story. See for instance OECD (2005b).
} 
Figure 8. The efficiency of secondary education in relation to OECD PISA scores, 2005

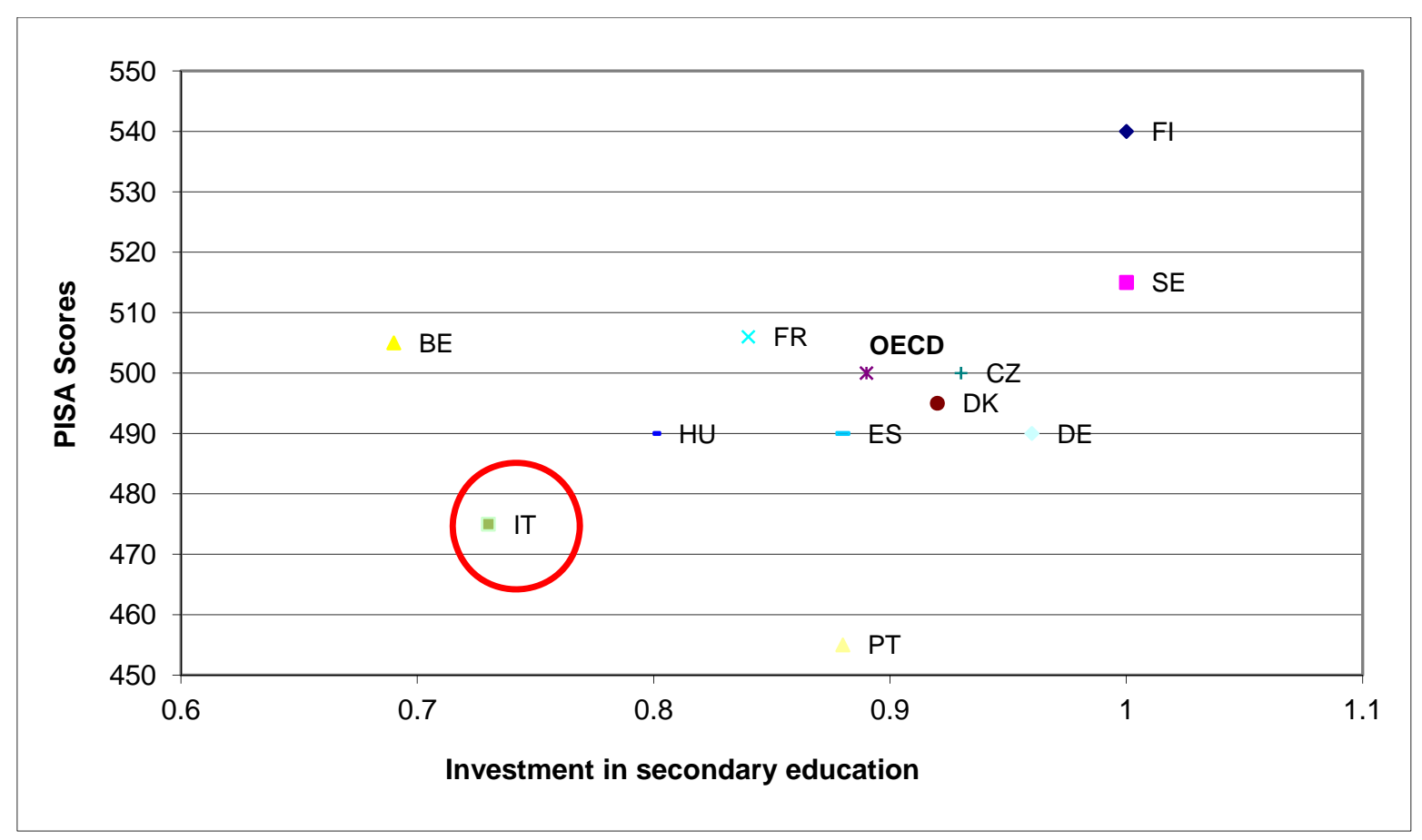

Source: Afonso and Aubyn (2006)

Investment in training is lower in Italy than in most European countries (OECD, 2011b). OECD studies show that participation in on-the-job training and adult education in Italy is also low in comparison to other OECD member countries (OECD, 2011a). It is also worth mentioning that less money has been invested in university education in the south than in other areas of the country (Ciccone et al., 2006).

\section{Job quality: temporary and part-time working}

Over the last 15 years, Italy has seen growth in non-standard forms of employment, accompanied by new labour laws and incentive mechanisms ${ }^{3}$ (Adam and Canziani, 1998; Hernanz and Toharia, 2006). Destefanis and Fonseca (2007) indicate that in central and northern Italy, there has been simultaneous growth of both non-standard and standard work. However, in the south, the growth of non-standard work is a "substitute" for standard labour. This has contributed to growing insecurity and lower employment stability in the labour force, which is not conducive to investments in human capital.

Part-time employment has become significant across the board, although significant differences can be found among sectors and between different areas of the country. In 2006, the share of part-time employment was just over $11 \%$ in the Mezzogiorno, versus the national average of $13 \%$. Part-time contracts are prevalent in the central regions, which are also characterised by a high and increasing female participation rate. Part-time employment in the north west is slightly below the national average, while in the north east, it is slightly above. Part-time work is mainly taken up by women who reside in the centre

\footnotetext{
${ }^{3}$ Data from the ISTAT Labour Force Survey for the 1993-2006 period shows that the increase of part-time work mainly occurred after 1997, the year of approval of the Treu Act. Part-time work decreased in the first half of this decade before once again growing significantly from 2004.
} 
north, with higher rates in the north east. In the southern regions, if an exception is made for Sardinia, the weight of female part-time employment is quite low on average.

Looking at the distribution by sector, part-time employment is widespread in services, while less present in construction and industry. Temporary employment which also includes seasonal work is widespread in the agriculture sector.

\section{The policy context}

\section{Labour market policy in Italy}

In terms of labour market policy, Italy is considered a fairly centralised country. The bulk of labour market legislation is established and enforced nation-wide by the central government. However, the twenty regions (the TL2 bodies), have had some law-making authority for almost 40 years and recently the presence of the regional governments has been growing in importance.

\section{Training and skills}

In Italy, training policies aimed at skills formation are financed by the national and regional government as well as European Social Fund (ESF). Financing is based on three lines of action:

1. School-to-work transition;

2. Vocational training;

3. Lifelong learning. (Acts 236/1993 and 53/2000, inter-professional funds)

1. School-to-work transition

To support school-to-work transitions, apprenticeship is used as the dominant policy tool. In recent years, training-work contracts have almost totally disappeared. Apprenticeship is an employment contract aimed at encouraging the integration of young people into the labour market through the acquisition of specific skills in response to demand expressed by firms. Apprenticeships combine work (often through paid employment) and learning in the vocational education system.

The Act 30/2003 outlines three types of apprenticeship schemes:

- A basic apprenticeship contract for young people aged 15 to 18 , which includes participation in a minimum of 240 hours per year in school outside of work to acquire skills in language, mathematics, computing, vocational guidance and civic education.

- Apprendistato professionalizzante: This apprenticeship contract leads to the attainment of a qualification through on-the-job training and technical and professional learning for young people aged 18 to 29. Attendance of at least 120 hours per year is usually expected in courses outside of work. Under Act 133/2008 a new model of apprenticeship was introduced, enabling companies to implement on-the-job training on the basis of national, territorial and sectoral agreements between social partners.

- Apprenticeship contract for advanced training and research: for young people aged 18 to 29 (including those working in the public sector) who require high levels of professional training in their field of research to enter professional associations. 
On an annual basis, the Ministry of Labour gives the regions (and the autonomous provinces of Trento and Bolzano) the financial resources for these various types of apprenticeship schemes. The distribution is based on 70\% for the number of apprentices employed and 30\% for the number of apprentices trained. For 2010, the Ministry of Labour distributed 100 million EUR. The regional distribution is given in Table 4.

Table 4. Apprenticeship schemes - resources and uses in 2010

\begin{tabular}{|l|l|l|l|l|}
\hline Regions/Provinces & \multicolumn{1}{|c|}{$\begin{array}{c}\text { Resources } \\
\text { (Euros) }\end{array}$} & $\begin{array}{c}\text { Employed } \\
\text { apprentices }\end{array}$ & $\begin{array}{c}\text { Registered } \\
\text { apprentices }\end{array}$ & $\begin{array}{c}\text { Percentage } \\
\text { registered/employed }\end{array}$ \\
\hline PIEMONTE & $10,853,930$ & 50,360 & 22,510 & $45 \%$ \\
\hline VALLE D'AOSTA & 516,000 & 1,733 & 464 & $27 \%$ \\
\hline LOMBARDIA & $17,174,934$ & 109,505 & 19,589 & $18 \%$ \\
\hline BOLZANO & $1,333,574$ & 4,472 & 3,688 & $82 \%$ \\
\hline TRENTO & $1,933,444$ & 6,729 & 5,215 & $78 \%$ \\
\hline VENETO & $10,686,562$ & 71,835 & 10,200 & $14 \%$ \\
\hline FRIULI V.G. & $3,582,104$ & 11,611 & 10,122 & $87 \%$ \\
\hline LIGURIA & $2,688,230$ & 18,189 & 2,502 & $14 \%$ \\
\hline EMILIA ROMAGNA & $14,249,828$ & 56,624 & 34,656 & $61 \%$ \\
\hline TOSCANA & $7,321,000$ & 52,163 & 5,401 & $10 \%$ \\
\hline UMBRIA & $2,262,223$ & 15,899 & 1,787 & $11 \%$ \\
\hline MARCHE & $4,650,633$ & 26,029 & 7,252 & $28 \%$ \\
\hline LAZIO & $7,687,272$ & 58,895 & 3,455 & $6 \%$ \\
\hline ABRUZZO & $1,752,591$ & 10,711 & 2,248 & $21 \%$ \\
\hline MOLISE & 516,000 & 1,72 & - & - \\
\hline CAMPANIA & $2,727,679$ & 21,132 & 1,100 & $5 \%$ \\
\hline PUGLIA & $3,780,325$ & 28,531 & 1,931 & $7 \%$ \\
\hline BASILICATA & 516,000 & 2,736 & - & - \\
\hline CALABRIA & 926,995 & 7,877 & - & \\
\hline SICILIA & $2,995,050$ & 25,450 & - & $34 \%$ \\
\hline SARDEGNA & $1,845,626$ & 9,595 & 3,273 & $\mathbf{2 3} \%$ \\
\hline TOTAL & $\mathbf{1 0 0 , 0 0 0 , 0 0 0}$ & $\mathbf{5 9 1 , 8 0 0}$ & $\mathbf{1 3 5 , 3 9 3}$ & \\
\hline
\end{tabular}

Source: Inps (2009)

\section{Vocational training}

Vocational training courses are designed to develop skills required by the labour market or to build on professional qualifications. They are organised at all education levels: post-compulsory education, post diploma and university degree, as well as post graduate courses. They are financed by the European Social Fund, regional and provincial funding, and are organised by public, private or affiliated training centres as well as by private firms. Vocational training is offered to:

- young people and adults seeking employment;

- disadvantaged groups (disabled, former prisoners, immigrants, drug addicts, etc.);

- laid off workers or those in "mobility" lists (the latter being a programme that combines income support to laid off workers with hiring subsidies to firms);

- $\quad$ workers who need retraining or professional upgrading. 
Planning of training courses is delegated to the regions on the basis of surveys in areas considered particularly strategic for regional development. The training programmes are designed and carried out in an integrated manner by universities, secondary schools, vocational training centres and firms. An important example of vocational training courses were the Istruzione e formazione tecnica superiore (IFTS) courses, established by Act 144/1999 (Article 69) and geared at training post-secondary professionals. These courses aimed to (i) facilitate the entry of young people into the labour market, offering highly professional training and creating connections with university-level education; and (ii) provide employees with an opportunity to receive a technical higher education. These courses were tailored for young people and adults that were employed or seeking employment, with or without a high-school diploma.

\section{Lifelong learning}

Lifelong learning includes training for working adults and is aimed at re-training or professional skills upgrading. It is aimed primarily at:

- employees of firms and public or private organisations that have a corporate training plan;

- $\quad$ employees who submit an application for individual training;

- $\quad$ employees of any private firm that are laid-off;

- $\quad$ employees of any private firm over the age of 45 years.

Lifelong learning activities are regulated through three main acts:

a) Act 236/1993

This is the basic Act for the national system of lifelong learning. This law has undergone significant changes over time, adapting to the demands of raising skills levels for workers, but also to the changing socio-economic conditions of local businesses. Gradually, there has been a move from funding firm-based training to the introduction of vouchers supporting individual training. The recipients of these interventions are:

- $\quad$ Training operators as defined by Act 40/1987;

- Employees in firms benefiting from the lay-off scheme under Act 223/1991;

- Employees in firms that contribute at least $20 \%$ of the training cost;

- Employees on “mobility” lists;

- Individuals who are not employment and are registered at a job centre and/or participated in community service.

In the last three years, this act has offset the impacts of the current recession by extending training for workers affected by the crisis and for unemployed youth who have had an employment contract terminated by December 31, 2008. It provides on-the-job training and introduces measures for the re-employment of workers on social security. 


\section{b) Act 53/2000}

This act contains provisions for encouraging individuals with children to participate in training and its recipients are employees who wish to acquire new skills. Training can last up to 11 months and includes training requested by the individual worker, or by a firm through regional training plans or industrial agreements (between social partners). It can include reductions in working time. Financing comes from the Interprofessional funds for lifelong learning.

c) Act 388/2000 - Interprofessional Funds for Lifelong Learning (Fondi Paritetici Interprofessionali per la formazione continua)

The Interprofessional Funds for Lifelong Learning are promoted by companies and the social partners. They cover:

- Firm-level, sectoral and regional training plans, individually or jointly organised by firms;

- Individual training plans;

- $\quad$ Other activities related to training initiatives.

There are currently 18 Interprofessional Funds (listed in Section 2 in the Appendix) authorised by the Ministry of Labour, enrolling more than 500000 firms (42\% of the total) and over six million employees (nearly $60 \%$ of the total). Companies choose a given fund and submit a training proposal for funding. This proposal describes the training activities to be carried out, together with the financial plan and any appropriate documentation (such as an analysis of training needs). The proposal must be accompanied by an agreement between social partners articulating the aims of the plan. The major training topics are personal skills development, foreign languages, management and administration. Between January 2009 and June 2010 (see Isfol, 2011), over 9800 training plans representing about 39500 initiatives have been approved for funding. This equals over 73 million hours of training given to approximately 1288000 participants from more than 32500 firms. Most of the training plans are focused on skills maintenance/upgrading (36.5\%), or firm competitiveness and innovation (25\%). From a territorial standpoint, almost a quarter (23.9\%) of the approved plans was distributed in Lombardia, with the second highest allocation in Veneto (13.4\%).

In order to implement the training plans, firms can conduct the training through institutions or agencies (in 50.5\% of the approved projects); consulting and/or training societies; public or private schools; public or private research institutes; and universities.

\section{Policy related to skills demand}

In recent years, two important pieces of legislation relating to state funding for $R \& D$ and innovation have been implemented in Italy. The first was the Ministerial Decree 593/2000, which regulates the management of the following three funds.

- FIT (Fondo Innovazione Tecnologica) was introduced in 1982 to encourage innovation and the commercialization of industrial research from small-medium firms. It involves a grant for R\&D expenditures (from 35\% to 70\% of total expenditure); the subsidy depends on the firm size and location. Spending on this fund amounted to 57 million EUR in 2009.

- FAR (Fondo Agevolazione Ricerca) was instituted in 1999 and was targeted to firms, universities, research centres (including parchi scientifici e tecnologici). Grants can be up to $50 \%$ 
of total costs for industrial research; up to $25 \%$ for activities related to the design, testing, and development of new products, processes or services. Further grants are provided for specific cases (see Ministerial Decree 593/2000). Spending on this fund amounted to about 279 million EUR in 2009.

- Fondo Unico Regionale which includes a range of subsidies (interest rate rebates or grants) that are directly managed by the Regions (Act 317/1991, Act 598/1994, Act 140/1997). The main among them is Act 598/1994, Investimenti per l'innovazione e la tutela ambientale, which is a subsidy for the innovation activities of small-medium firms. A grant can be added for firms located in EU's objective 1 areas. Spending on this fund amounted to about 240 million EUR in 2009.

In order to articulate more effective and focused directions for economic policies under the Lisbon Strategy, the European Council invited Member States in 2005 to prepare action plans called three year National Reform Plans (NRP). The Italian Plan was focused on national strategic plans (programmi strategici) and the technological districts (distretti tecnologici). The former was designed as an integrated set of research actions, feeding into each other and aiming at short-, medium-, and long-term goals. Technological districts are operational models enabling small and medium-sized as well as large firms to collaborate on innovative projects.

A further result of the NRP was the launch of a new industrial policy in 2006 called Industry 2015. It identified networks of firms, innovative financing and Industrial Innovation Projects (PII) as new tools to ensure the strategic repositioning of Italy's industry in the global economy. It also identified specific types of products and services that carry a high level of innovation in strategic sectors of the country. These include energy, sustainable mobility, life sciences, new technologies for a "Made in Italy industry", and cultural heritage. Industry 2015 is based on collaboration between local authorities, businesses, universities and research centres which operate under the guidance of a project manager. Along with the Industrial Innovation Projects, Industry 2015 provides more traditional forms of state funding for innovation and $\mathrm{R} \& \mathrm{D}$. The latter relate in particular to:

- $\quad$ Fondo per gli Investimenti nella Ricerca Scientifica e Tecnologica (Funds for investments in scientific research and technology), which combines FAR resources with other forms of state funding related to basic research;

- Fondo per la competitività e lo sviluppo (Funds for competitiveness and development), which combines FIT resources with other forms of cohesion policies;

- tax credits equal to $10 \%$ of the costs incurred for R\&D, increased to $15 \%$ for contracts with universities and research centres, in accordance with current EU guidelines on state funding. Spending for this fund amounted to 633 million EUR in 2009.

Besides the Fondo Unico Regionale, there has been the Pacchetto Integrato di Agevolazioni or Pia Innovazione, which groups the provisions of FIT in a single policy instrument - a very popular tool of cohesion policy. Pia Innovazione is an intervention which targets firms located in Southern Italy wishing to promote activities related to the design, testing, development and prototyping of new products, processes or services, as well as investments for production. Activities could include education and training expenses for employees.

In the last couple of years, state funding for R\&D has increased from 740 million EUR in 2008 to 1.3 billion EUR in 2009 (Brancati, 2010). This increased investment can be primarily attributed a new policy tool - a tax credit for R\&D. There has also been an increase in the funding for policy measures under the 
Fondo Unico Regionale (from 170 EUR million in 2008 to 240 million EUR), while funding for the two traditional policy tools (FIT and FAR) have reminded roughly the same. All this has meant that the proportion of R\&D funding is now about $36 \%$ of total national funding. However, funding in this field has generally increased more for the northern and central regions than for the rest of Italy. The proportion of R\&D over total funding is about $60 \%$ in Emilia-Romagna, Lombardia, Toscana and Veneto. This percentage goes down drastically in the Mezzogiorno regions, with the exception of Basilicata (39\%), and, to some extent, Campania (34\%). These values are close to the national average of $38 \%$. In the Mezzogiorno, funding tends to still favour purchases of machinery and equipment.

\section{Policies to support skills matching}

National and, especially, regional policy makers have only recently begun to focus on the matching of skills supply and demand in Italy. Resources and attention are devoted to developing skills supply (training) and demand (R\&D, innovation), rather than promoting a supply-demand balance. Indeed, the 2010 Labour Plan from the Ministry of Labour announced that Italy, as compared to other countries had a significant mismatch between labour demand and supply. It blamed the "total inadequacy of the training system" for this state of affairs above anything else. The lack of a robust socio-economic infrastructure which can bring together workers and firms was also noted but is seen as less of a contributing factor.

The last 15 years have been characterised by a process to reform the public employment service (PES). The PES has now become a system geared to the delivery of active employment policies and supporting the development of a preventive approach to unemployment. However, this effort has been rather weak vis-à-vis the extent of reforms enacted in other departments of labour-market policy (see Pirrone and Sestito, 2008).

The argument that skills matching policies are weak is confirmed by statistics outlined in Table 5 below. While Italian public expenditure in labour market programmes (as a percentage of GDP) is roughly in line with the rest of OECD countries, it is well below the average especially for public employment services, administration, direct job creation and training policies.

Table 5. Public expenditure as percentage of GDP by type of intervention in selected OECD countries, 2009

\begin{tabular}{|l|l|l|l|l|l|l|l|l|l|}
\hline & $\begin{array}{l}\text { PES } \\
\text { and } \\
\text { adminis } \\
\text { tration }\end{array}$ & Training & $\begin{array}{l}\text { Job } \\
\text { rotatio } \\
\text { n and } \\
\text { job } \\
\text { sharin } \\
\mathbf{g}\end{array}$ & $\begin{array}{l}\text { Employm } \\
\text { ent } \\
\text { incentives }\end{array}$ & $\begin{array}{l}\text { Supported } \\
\text { employme } \\
\text { nt and } \\
\text { rehabilitat } \\
\text { ion }\end{array}$ & $\begin{array}{l}\text { Direct } \\
\text { job } \\
\text { creatio } \\
\mathbf{n}\end{array}$ & $\begin{array}{l}\text { Start-up } \\
\text { incentiv } \\
\text { es }\end{array}$ & $\begin{array}{l}\text { Out-of- } \\
\text { work } \\
\text { income } \\
\text { maintenan } \\
\text { ce and } \\
\text { support }\end{array}$ & $\begin{array}{l}\text { Early } \\
\text { retirem } \\
\text { ent }\end{array}$ \\
\hline Canada & 0.14 & 0.14 & 0 & 0.01 & 0.02 & 0.02 & 0.01 & 0.97 & 0 \\
\hline Denmark & 0.45 & 0.3 & 0 & 0.19 & 0.68 & 0 & 0 & 1.29 & 0.44 \\
\hline France & 0.26 & 0.36 & 0 & 0.1 & 0.07 & 0.15 & 0.04 & 1.4 & 0.02 \\
\hline Germany & 0.37 & 0.35 & 0 & 0.11 & 0.04 & 0.06 & 0.07 & 1.47 & 0.06 \\
\hline Italy & $\mathbf{0 . 1 1}$ & $\mathbf{0 . 1 6}$ & $\mathbf{0}$ & $\mathbf{0 . 1 5}$ & $\mathbf{0}$ & $\mathbf{0 . 0 1}$ & $\mathbf{0 . 0 2}$ & $\mathbf{1 . 2 8}$ & $\mathbf{0 . 1}$ \\
\hline Spain & 0.16 & 0.19 & 0.01 & 0.26 & 0.03 & 0.1 & 0.1 & 2.92 & 0.04 \\
\hline Sweden & 0.46 & 0.06 & 0 & 0.37 & 0.22 & 0 & 0.01 & 0.72 & 0 \\
\hline UK & 0.29 & 0.02 & 0 & 0.01 & 0.01 & 0 & 0 & 0.33 & 0 \\
\hline $\begin{array}{l}\text { OECD } \\
\text { countries }\end{array}$ & 0.16 & 0.18 & 0 & 0.1 & 0.09 & 0.07 & 0.02 & 0.95 \\
\hline
\end{tabular}

Source: OECD, 2011 
The low investment in active employment policies in Italy in comparison to the OECD average is also notable in Table 6.

Table 6. Public expenditure as a percentage of GDP in selected OECD countries, 2009

\begin{tabular}{|l|l|l|l|}
\hline & \multicolumn{1}{|c|}{ Total } & \multicolumn{1}{c|}{ Active policies } & \multicolumn{1}{c|}{ Passive policies } \\
\hline Canada & 1.33 & 0.35 & 0.98 \\
\hline Denmark & 3.35 & 1.62 & 1.73 \\
\hline France & 2.4 & 0.98 & 1.42 \\
\hline Germany & 2.52 & 1 & 1.52 \\
\hline Italy & $\mathbf{1 . 8 3}$ & $\mathbf{0 . 4 4}$ & $\mathbf{1 . 3 9}$ \\
\hline Spain & 3.82 & 0.86 & 2.96 \\
\hline Sweden & 1.85 & 1.13 & 0.72 \\
\hline UK & 0.66 & 0.33 & 0.33 \\
\hline OECD countries & 1.67 & 0.62 & 1.04 \\
\hline
\end{tabular}

Source: OECD, 2011

Furthermore, the reform process of public employment services is different among territories. In the north and centre, job centres are more oriented to the delivery of active, personalised services, compared to the prevalence of more minimalist services in the south (Ministero del Lavoro, 2008).

\section{Industrial relations}

According to some commentators (see Ebbinghaus and Visser, 2000) the European industrial relations systems can be divided into four types or regimes:

- Nordic corporatism: Industrial relations in the Nordic countries (Denmark, Finland, Norway and Sweden) are relatively centralised, and social partners interact closely with each other and with political decision-makers. Hence, collective bargaining is highly regulated via bipartite or tripartite agreements that are co-managed by the government.

- "Core" countries: Germany, Austria, Belgium are examples of this type/regime. Industrial relations are more segmented than in the Nordic countries. Nevertheless, social partners have an important role in co-ordinating labour market regulation. The state also intervenes in the industrial relations system, mainly through legislation.

- The Anglo-Saxon system: This system has been dominant in the United Kingdom and Ireland. In this system collective agreements are not legally binding and are mostly struck at the company level. Hence social partners lack the strong central organisation required to play an influential role in labour-market regulation. In Ireland, there has however been a strong move recently toward a system of tripartite dialogue at the national level.

- The Mediterranean system: This system exists in Greece, Portugal, and, to a lesser extent, in Spain. It is characterised by a long-standing role of the state in labour-market regulation. Highly politicised trade unions and an adversarial relationship between social partners has led to state intervention, which has in recent years taken the form of tripartite agreements.

Italy is closest to this fourth category. 


\section{Historical background ${ }^{4}$}

In the 1950s, Italy was characterised by a generally slack labour market (i.e. more workers than jobs), as well as by strong political divisions among the main trade unions (CGIL, CISL, UIL), which led to relatively weak implementation of nationwide wage agreements. Plant-level bargaining began to take a more and more important role, and in 1962 the powerful metalworkers' unions first put forward the idea of articulated bargaining, which meant that "national agreements should cover basic and minimum conditions, and that further bargaining could take place at the local level" (Allen and Stevenson, 1974). This procedure gradually spread first in the public sector and then spilled over into the private sector.

In 1969, industrial unrest gradually spread through the whole economy, peaking with the so-called 'hot autumn'. The main trade unions overcame their political divisions and united in action, which led to the promulgation of an act known as the Workers' Charter in 1970. This act considerably strengthened their power in the labour market and led to the introduction of restrictive hiring and firing legislation. In the wake of two oil crises, two-digit inflation and a highly volatile political environment, industrial relations in the 1970s were characterised by conflict. However, in February 1975 an important agreement took place between Confindustria (the national Confederation of Industries) and the unions concerning the wage indexation system. This agreement brought about a substantial rise in the degree of wage indexation, in order to maintain the purchasing power of the workers to offset inflation. The decrease of wage differentials between workers, along with an increasingly restrictive management of aggregate demand, began to reduce workers' militancy. The indexation system was gradually dismantled throughout the 1980s, which brought strong political divisions across the main unions.

The Italian economy at the beginning of the 1990s (in particular the public finance imbalances and difficulties in fulfilling the Maastricht Treaty requirements) led to a period of agreement regarding income policies. In July 1992, an agreement was signed by unions, Confindustria and government, abolishing the wage indexation system. This agreement also led to a flat-rate monthly raise of 20000 lire from January 1993. The agreement did not prevent the exit of the Lira from the European Monetary System, which took place in September 1992. However, the agreement was strong enough to resist a 15\% depreciation of the Lira and it created a new industrial relations system.

The new system is based on two levels of wage-bargaining. Firstly, there are national industry contracts, which set wages rules over a two-year time horizon (while dictating other aspects of the labour contract over four years). Wage rises at this level of bargaining are consistent with the target inflation rate, which is decided annually by the government. The potential discrepancy between the actual and target rate of inflation is one of the elements taken into account when national industry contracts are renegotiated after a two-year period. The second level of bargaining relates to plant-level bargaining, and is focused on the relationship between wages and firm productivity and profitability.

According to Brandolini et al. (2007), the 1992-93 Agreement was crucial in driving down inflation to the government's target level and co-ordinating, at least to some extent, wage bargaining. However, the diffusion of firm-level flexible wage-premia remained confined to firms of medium-large size. Productivity gains were only partly distributed to wages and insufficient elements of flexibility and differentiation were introduced in wage bargaining.

The 1992-93 Agreement signalled the beginning of tripartite agreements. In 1996 the Patto per il lavoro, outlined a new institutional framework centred on an integrated training system implemented with the Act 196/1996, which, among other innovations, defined the standards for the construction of a national

\footnotetext{
${ }^{4}$ The following brief historical account is mainly based upon Allen and Stevenson (1974); Sylos Labini (1977), Salvati (1980).
} 
system of training, established criteria for the certification of skills and amended the apprenticeship system. In 1998, the Patto sociale per lo sviluppo e l'occupazione implemented with the Act 196/1998, provided for the reinforcement of the training system, the development of new channels for education and integrated technical and vocational training as well as the strengthening of apprenticeship and traineeships schemes.

In 2003 Confindustria, CGIL, CISL and UIL signed another agreement ${ }^{5}$ asking for greater government expenditures on $\mathrm{R} \& \mathrm{D}$, in accordance with EU requirements. The social partners also proposed a move toward tax credits for private research. Finally, with regard to training and human resources development, there was a significant demand for an efficient, flexible, decentralised and nationally accredited system of training and skills.

In January 2009 CISL and UIL signed an agreement with Confindustria and the Government which led to a two-tier model of collective bargaining at the national and firm level, and proposed reduced taxes and social security contributions on wage increases provided by the "second-level of bargaining linking wage increases to the achievement of productivity, profitability, quality, efficiency and effectiveness and other elements relevant to improving competitiveness.”

The following sections highlight the main pieces of legislation devoted to the promotion of skills supply and demand at the regional and national level in Italy. While the purpose of the following pages is mainly descriptive, some policy implications will also be outlined. In particular the lack of attention of Italian policy-makers to the matching of skills demand and supply is highlighted.

\footnotetext{
${ }^{5}$ Accordo per lo sviluppo, l'occupazione e la competitività del sistema economico nazionale: priorità condivise in materia di politiche per la ricerca, la formazione, le infrastrutture e il Mezzogiorno (2003).
} 


\section{ANALYSING LOCAL DATA ON SKILLS SUPPLY AND DEMAND}

In order to know more about skills growth and balance and their relationship with the local economic structure, the OECD LEED Programme has created a diagnostic tool which enables quantitative information on skills matching. The labour market analyst Anne Green (see Green et al., 2003) proposes a useful typology to understand the complex relationship between skills and supply and demand which exists in different regions. According to this typology, regions can broadly fall into four different categories: regions experiencing a low-skills equilibrium; regions experiencing skills gaps and shortages; regions experiencing a skills surplus; and, lastly, regions experiencing a high-skills equilibrium (see Figure 9 below).

Figure 9. The OECD diagnostic tool

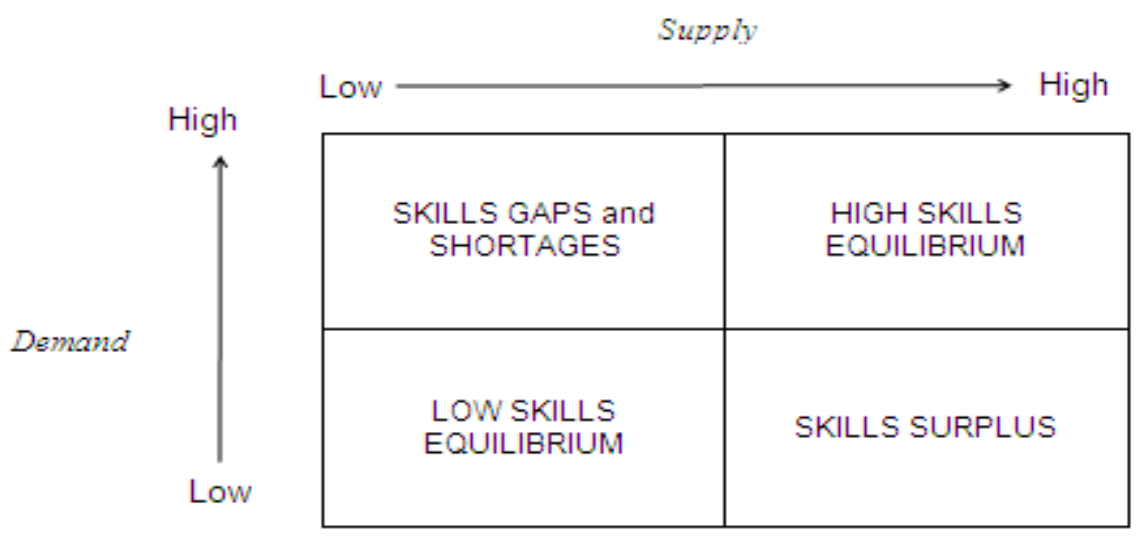

Source: Froy et al, 2009

In the context of demographic changes and limited geographical mobility, some areas experienced skills gaps and shortages before the current recession (the top left hand corner of the diagram), with such problems continuing today despite higher unemployment rates. Not all businesses or areas progress as fast as others in terms of adopting new technologies and adapting to changing markets. Coyle (2001) identifies a lag time of roughly 50 years between the development of new technologies and the ability of economies to fully take advantage of them. In such areas (particularly rural ones) a low skills supply can be met with low skills demanded by local employers - the low-skills equilibrium (Froy and Giguère, 2010a, 2010b).

In a low-skills equilibrium, a vicious circle can develop as it does not pay workers to remain in education if local firms are not seeking higher-level skills. At the same time, firms will be reluctant to raise their level of productivity and better utilise skills if there is a lack of well-educated workers within their locality (Snower, 1996; Burriell Lombart, 2004). This presents a difficult situation for policy makers. Improving the skills supply locally may produce a skills surplus, unless simultaneous attempts are made to improve demand. In such cases, trained people may leave the area at a young age to seek better quality employment opportunities elsewhere. Local policy makers often become diverted towards "fire-fighting" to fill labour shortages, as opposed to skills shortages. These labour shortages are often resolved through recourse to immigration, meaning that policy makers do not have an eye on the longer term strategic need 
to improve the quality and knowledge intensity of employment on offer and to increase the attractiveness of the labour market to residents and newcomers alike - and create a high-skills equilibrium. On the other hand, in relatively dynamic areas, firms attempting to improve their product market strategies could demand higher skills than are available in the local workforce. Such areas may have experienced skills shortages before the current recession, with these problems continuing today despite higher unemployment rates (Froy and Giguere, 2010; Froy, Giguere and Meghnagi, 2011).

In order to give a quantitative representation of the diagnostic tool and assess where sub-regions fall in the diagnostic tool, a number of proxies on skills supply and demand have been identified and are available at the TL3 level. Besides finding appropriate proxies for this task, there is a further methodological point that must be considered. The OECD diagnostic tool assumes a degree of homogeneity within sub-regions which may not exist in reality. According to the OECD, one should look to local labour markets with a population of around 800 000. Markets with a smaller population may always be consistent with mismatches between skills supply and demand. Table 7 provides some percentile values for the populations of Italian local employment systems (SLL's), provinces and regions. Provinces are taken as the territorial unit of analysis to explore statistically significant features of the diagnostic tool.

Table 7. Population for various territorial classifications, 2006-08

\begin{tabular}{|l|l|l|l|}
\hline \multicolumn{1}{|c|}{ Percentile } & \multicolumn{1}{|c|}{ SLL } & \multicolumn{1}{|c|}{$\begin{array}{c}\text { Province } \\
\text { (TL3) }\end{array}$} & Region (TL2) \\
\hline $5 \%$ & 6,978 & 141,195 & 223,26 \\
\hline $25 \%$ & 13,718 & 231,330 & $1,006,877$ \\
\hline $50 \%$ & 34,276 & 369,427 & $1,835,088$ \\
\hline $75 \%$ & 79,595 & 580,676 & $4,830,481$ \\
\hline $95 \%$ & 268,503 & $1,239,808$ & $7,724,177$ \\
\hline
\end{tabular}

Source: own calculations on ISTAT data 


\section{Box 3. Diagnostic tool methodology}

Data has been collected mostly from the Labour Force Survey for 2001-09. Skills supply is calculated using educational attainment (the share of workers with post-secondary education). To calculate skills demand the OECD uses a linear combination (with 0.75 and 0.25 weights respectively) of GVA per employee and employment in mediumhigh skilled occupations (the share of workers with managerial, professional or associate professional jobs). GVA per employee is taken from territorial accounting data for 2001 and 2008. In the analysis, observations are normalised taking their difference vis-à-vis the overall median value, and dividing the result by the difference between the ninth and first deciles. See formula below.

$$
\left(X_{i}-X_{m e d}\right) /\left(X_{9 t h}-X_{1 s t}\right)
$$

Where:

$$
\begin{aligned}
& X_{i}=\text { value for TL3 } i \\
& X_{\text {med }}=\text { median } \\
& X_{9 t h}=9^{\text {th }} \text { decile } \\
& X_{1 s t}=1^{\text {st }} \text { decile }
\end{aligned}
$$

Supply and demand indices can be computed in two separate ways - either by comparing sub-regions with similar industrial characteristics and degree of urbanisation, or by comparing sub-regions nationwide. In the first case the formula shown above applies only to the sub-regions belonging to the benchmarking group (e.g. sub-regions having a dominant primary sector); in the second case it applies to all sub-regions in the country (Froy, Giguere and Meghnagi, 2011). The sectoral approach seems to be particularly interesting for Italy. In particular, the distribution of provinces with high employment in the secondary or tertiary sector ${ }^{6}$ gives complementary information on the Italian labour market and economic structure.

\section{Findings}

Figures 10 and 11 show sub regions with a strong secondary or tertiary sector and the supply and demand indicators are calculated respectively in each benchmarking group. Figure 10 shows that the provinces are unevenly spread over the four quadrants reflecting the heterogeneity of the Italian manufacturing sector. Most provinces in this benchmarking group are in the north or centre of Italy, confirming that the secondary sector is less developed in the south. Most provinces from the north (Lombardy and Veneto) have good levels of productivity and there appears to be some skills shortages among the working population. On the contrary some provinces from the centre (Abruzzi and Umbria) are in the skills surplus quadrant.

\footnotetext{
${ }^{6}$ The four metropolitan areas (Rome, Milan, Naples and Turin) identified by the OECD Directorate for Public Governance and Territorial Development have been excluded from the calculations.
} 
Figure 10. Secondary Sector Provinces, 2009

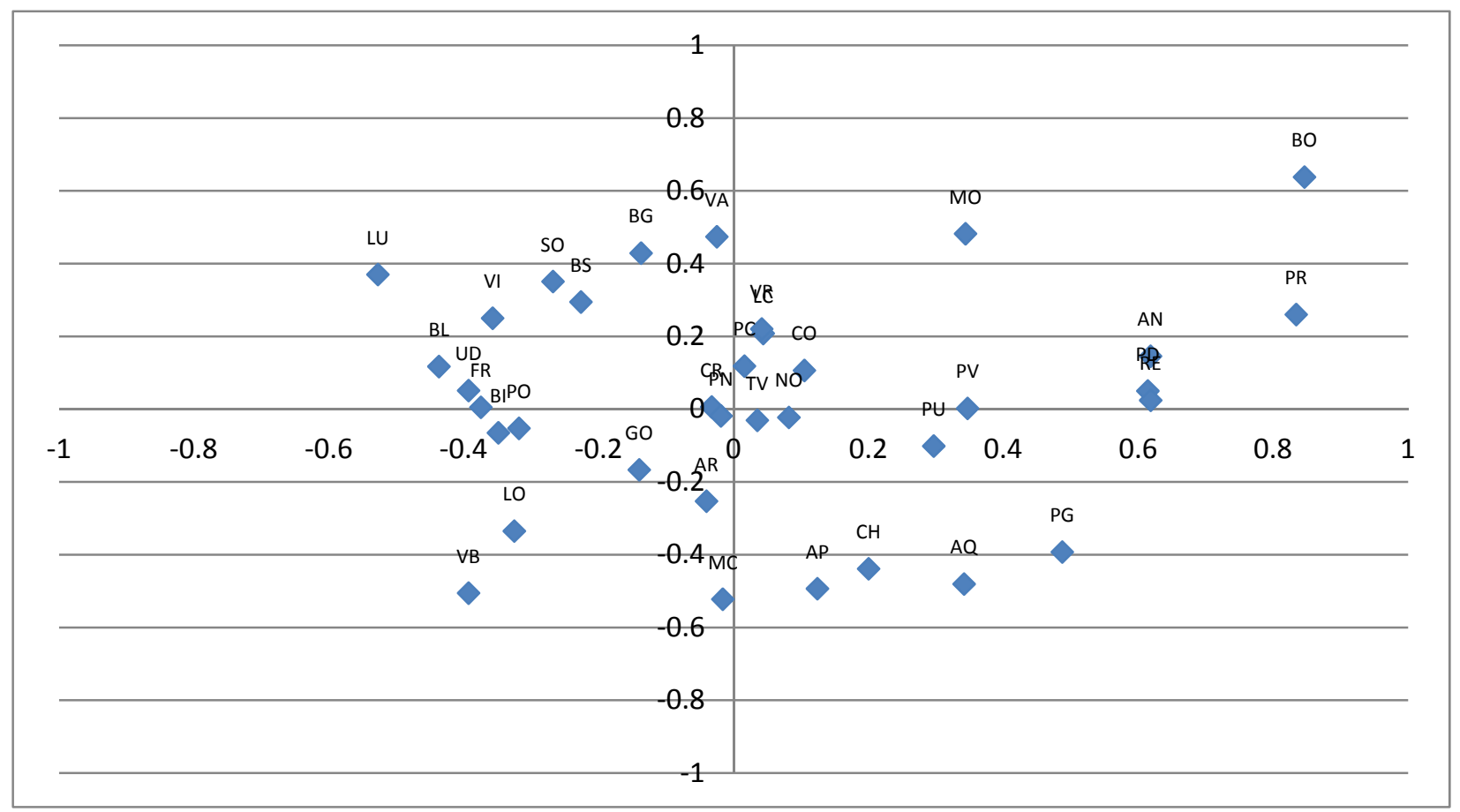

Source: own calculations on ISTAT data

Figure 11 shows the distribution of sub regions having a dominant tertiary sector. Fewer regions belong to this benchmarking group, therefore geographical patterns are less clear. Interestingly, Venice falls in the skills shortages quadrant which may mean that skilled workers have left the area. Avellino, one of the provinces in Campania, is in the low skilled equilibrium but seems to have improved its performance in comparison to 2001. 
Figure 11. Tertiary Sector Provinces, 2009

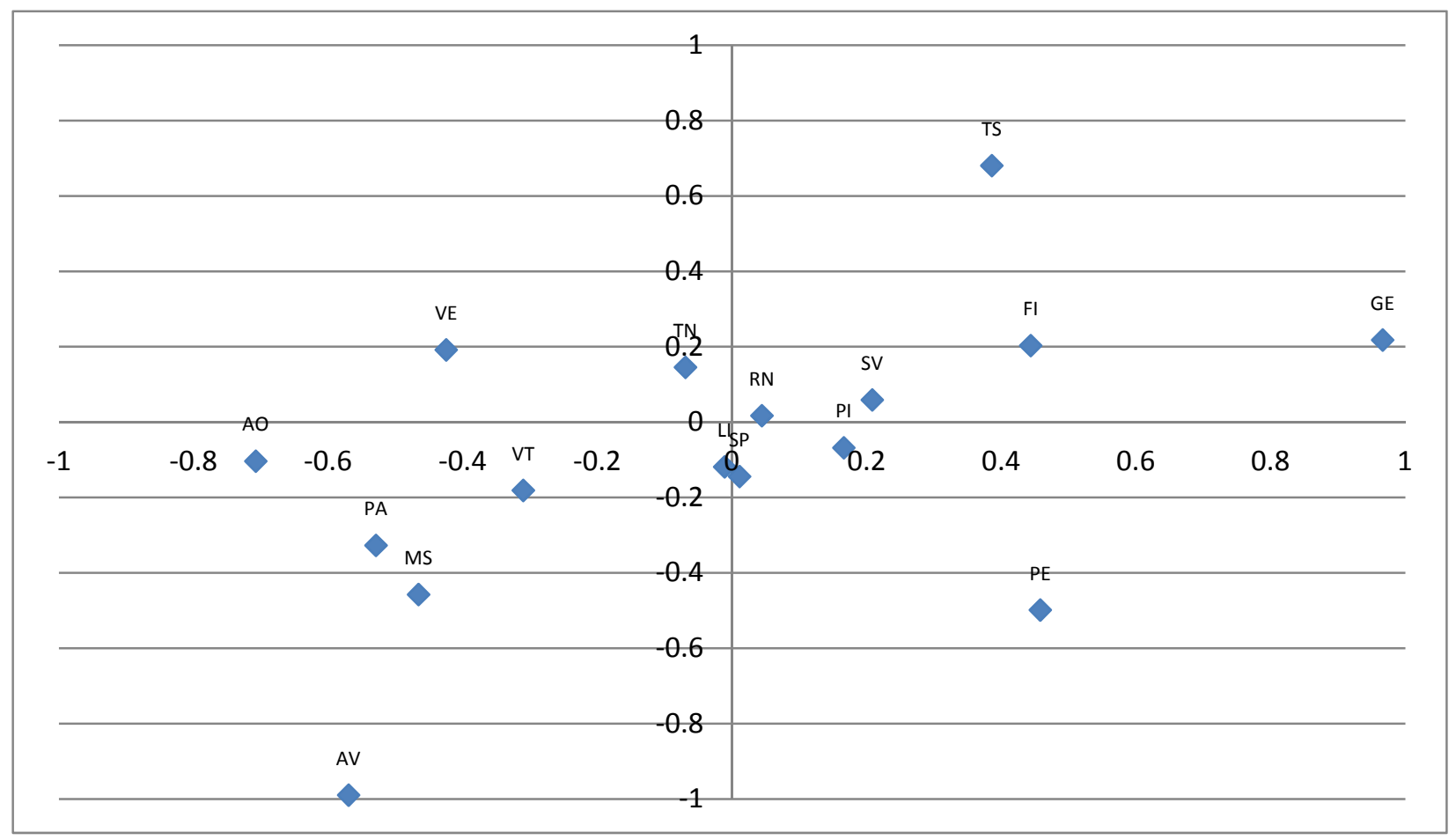

Source: own calculations on ISTAT data

Hidden factors influencing the equilibrium?

In order to assess whether the position of the provinces on the four quadrant model is related to their structural characteristics, a multinomial logit model (MLM) has been set out. ${ }^{7}$ The categories of dependent variables of the model are given by the four typologies envisaged by the diagnostic tool, and the regressors are related to the structural factors evoked in the analysis of the main features of the Italian economy. Some relevant proxies, described in Table 8 below have been found at the TL3 level. Their values are reported in section 3.2 of the Appendix.

\footnotetext{
${ }^{7}$ A brief presentation of this technique is provided in Section 3.1 of the Appendix.
} 
Table 8. The multinomial logit model. Variables used

\begin{tabular}{|c|c|c|}
\hline Variable name & Short explanation & Source \\
\hline Employment by sector & $\begin{array}{l}\text { Specialisation in the primary, secondary } \\
\text { or tertiary sectors, and for metropolitan } \\
\text { areas }\end{array}$ & Labour Force Survey, Istat \\
\hline Geographical classification & $\begin{array}{l}\text { North-West (Piedmont, Val } \\
\text { d'Aosta, Lombardy, Liguria), } \\
\text { North - East (Trentino-Alto } \\
\text { Adige, Veneto, Friuli-Venezia } \\
\text { Giulia) } \\
\text { Centre (Toscana, Umbria, } \\
\text { Marche, Emilia Romagna) } \\
\text { - } \quad \text { Intermediate between Centre } \\
\text { and South (Lazio, Abruzzi) } \\
\text { The dynamic Mezzogiorno } \\
\text { regions (Molise, Puglia, } \\
\text { Basilicata, Sardinia) } \\
\text { The less dynamic } \\
\text { Mezzogiorno (Campania, } \\
\text { Calabria, Sicilia). }\end{array}$ & $\begin{array}{l}\text { Own classification based on } \\
\text { similarities across regions that } \\
\text { cannot be measured at the TL3 } \\
\text { level (e.g. role of the hidden } \\
\text { economy and of regional laws). }\end{array}$ \\
\hline Union density & $\begin{array}{l}\text { Union members divided by the number of } \\
\text { employees }\end{array}$ & $\begin{array}{l}\text { CGIL and CISL union data and } \\
\text { Labour Force Survey, Istat }\end{array}$ \\
\hline Employment of women & Share of female in the labour force & Labour Force Survey, Istat \\
\hline Employment of young people & $\begin{array}{l}\text { Share population } 15-24 \text { in the labour } \\
\text { force }\end{array}$ & Labour Force Survey, Istat \\
\hline Foreign population & Share foreign population & Population data, Istat \\
\hline Part-time & Share of part-time workers & Labour Force Survey, Istat \\
\hline Temporary contracts & Share of temporary workers & Labour Force Survey, Istat \\
\hline University & $\begin{array}{l}\text { Two different measures of university } \\
\text { attractiveness, which we take as a proxy } \\
\text { both of higher education investments and } \\
\text { quality. }\end{array}$ & Dotti et al. (2010) \\
\hline District & $\begin{array}{l}\text { Provincial share of distretti's exports, } \\
\text { deemed a good proxy of the weight of } \\
\text { distretti in the provincial economy }\end{array}$ & San Paolo research institute \\
\hline Population & Provincial population & Population data, Istat \\
\hline Firm size & $\begin{array}{l}\text { Average size in terms of workers of local } \\
\text { establishments }\end{array}$ & 2001 Census, Istat \\
\hline Number of patent applications & $\begin{array}{l}\text { Number of patent applications to the } \\
\text { European Patent Office (then divided by } \\
\text { the population of the province) }\end{array}$ & CRENOS \\
\hline
\end{tabular}

MLM results are based on the probability of being in the low-skills equilibrium. As two years were considered (2001 and 2009), a dummy ${ }^{8}$ for 2009 was added to the variables listed above. For the sector dummies, sector 1 (the primary sector) was the default case, while this property applies to Zone 6 for the area dummies.

\footnotetext{
${ }^{8}$ Dummy variables can take a value of 0 when the condition is not met or 1 when it is met.
} 
Two different MLMs have been brought to the data (see the Appendix, Section 3.3). Model 1 contains the territorial and the year dummies. Examining the significance of the RRRs in this model suggests that being in the north-centre region highly increases the odds of being in the high-skills rather than a low-skills equilibrium. In line with evidence from Figures 10 and 11, there is a correlation between being located in the centre and the probability of being in the skills-surplus quadrant rather than in the low-skills equilibrium. This effect may be linked to the large number of higher education institutions in that part of the country.

Model 2 attempts to shed further light on this matter by adding the other features enumerated in Table 8 to the sectoral dummies. The results of this model suggest that having a strong tertiary sector greatly increases the probability of being in a high-skilled rather than a low-skilled equilibrium. Having a strong secondary sector has a much weaker effect. This is interesting, as it aligns with some important aggregate problems of the Italian economy that were highlighted in the previous pages. On the other hand, a strong secondary sector is associated with a higher probability of being in the skills-shortage quadrant rather than in a low-skills equilibrium.

Among the other variables, population size plays a very important role. Contrary to what was expected, population size is not inversely related with skills shortages or surpluses. Having a large population increases the odds of being in a high-skills equilibrium. It also increases the odds of being in the skills-shortage quadrant rather than in a low-skills equilibrium. The negative impact of the metropolitan dummy variable on the odds of being in a high-skills equilibrium suggests at any rate that the population size effect is not likely to be monotonic.

Somewhat surprisingly, average firm size does not have a significant role. Similarly and almost as surprising, the distretii does not have a significant impact either. On the other hand, hosting an attractive university is likely to have a significant positive impact on skills supply (all these results are robust across various specifications). Regarding the labour market structure, no role is detected for part-time workers. On the other hand, an inverse relationship is evident between skills demand and the share of temporary workers.

In Model 2, there is no significant extra impact that can be perceived for the area dummies. This means that the sectoral dummies and other structural characteristics substantially capture the distinctive territorial patterns of skills supply and demand throughout the Italian economy. There is little doubt that such variables are of some economic as well as statistical significance for the analysis of skills balance in Italy.

\section{Applying the diagnostic tool}

Analysis with the OECD diagnostic tool was further developed by applying some important measures of labour market performance to the tool. Figure 12 shows the results for the Italian provinces, combining 2001 and 2009. 
Figure 12. Labour-market performance according to the OECD diagnostic tool typology, Italian provinces, combining 2001 and 2009.

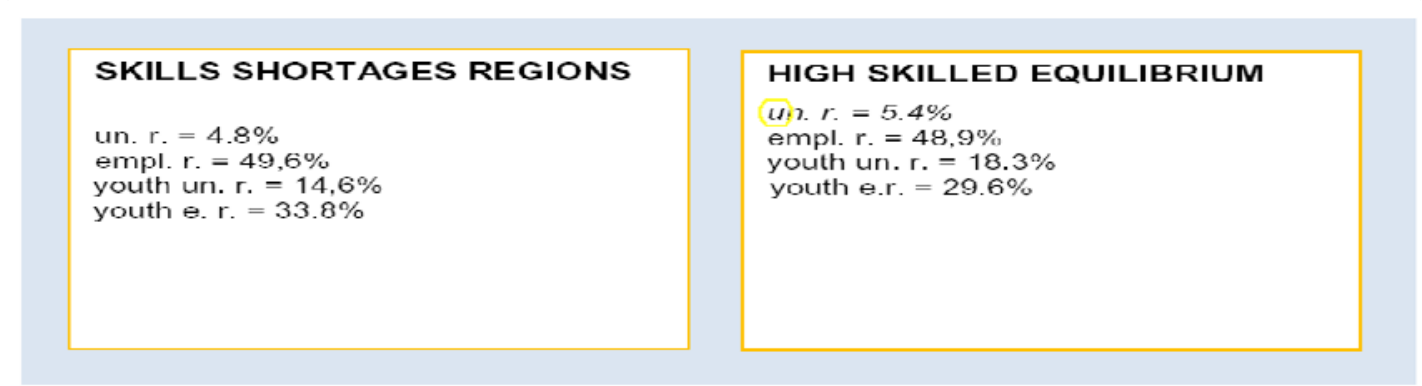

LOCAL SKILLS PROFILES

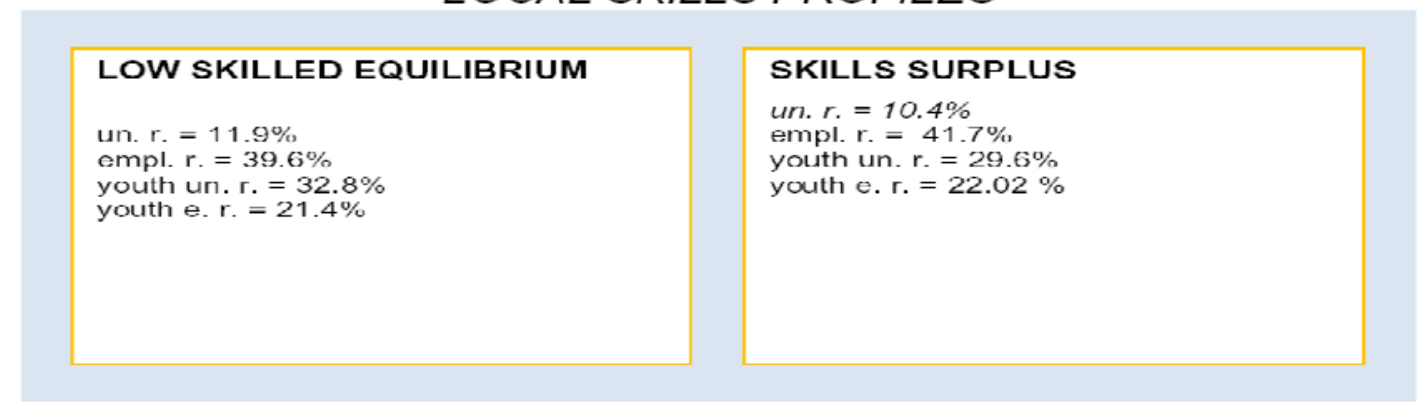

Source: own calculations on ISTAT data

Legend: un. $r .=$ unemployment rate (mean), empl. $r .=$ employment rate (mean), youth un. $r .=$ unemployment rate, age 15-24 (mean) and youth empl. r. = employment rate, age 15-24 (mean).

The percentages in the four quadrants are the mean unemployment and employment ${ }^{9}$ rates (total and for population aged from 15 to 24) for provinces located in each of the quadrants. Clearly, the values for the low-skills equilibrium are much less favourable than in the other two quadrants. It is interesting to note that the unemployment rate is higher in the low-skills quadrant, unlike what could be expected from the definition of low-skills equilibrium discussed earlier. This phenomenon is related to the presence of many southern provinces in this quadrant. The combination of low productivity and bad labour-market performance is explained by the effect of nationwide wage bargaining on the territorial adjustments of wages to productivity (see for instance, Buti et al., 1998). Values in the skills shortage quadrant are far from bad, but their sustainability in the absence of sufficient investments in human capital should be questioned. In Table 4.1 in the Appendix the four labour-market indicators are reported for each province.

\footnotetext{
${ }^{9}$ Employment rates are calculated vis-à-vis the total population (not vis-à-vis the working-age population).
} 


\section{POLICY FINDINGS}

\section{National survey to Italian regions}

To understand the obstacles and barriers to effective skills utilisation and the current policies in place to address these issues, a survey with national level experts from various institutions and organisations was conducted in six regions of Italy in collaboration with ISFOL. Results show that wages are relatively lower in the south than in the north and centre of the country, suggesting that national bargaining has a more limited impact in regions where labour productivity is low. Low wages appeared to be a particular problem in the personal services and secondary sectors - both construction and manufacturing. Based on the results of this survey and from the implementation of the diagnostic tool, Campania and Veneto were chosen as case study regions for the project with a view to comparing the north and south. Similarities and differences between the two case study regions are presented in the following section.

\section{Overview of policy initiatives at the regional level}

\section{Campania}

Skills needs in Campania are monitored through the Excelsior database from the Chamber of Commerce. The Ministry of Labour is currently reconstructing a database gathering data from all jobcentres, but there are various administrative and organisational problems with the distribution of this data. The main challenges in the region are related to an under-performing bureaucracy, lengthy administrative procedures and a lack of basic skills. The Chamber of Commerce of the Salerno province is conducting a study on these issues.

There are highly diverging views about current skills levels in Campania. There is a common view that more communication is needed between firms and the educational system. High-skilled youth are currently leaving the region and the public employment service ${ }^{10}$ is not viewed as effective for those individuals who want to enter the labour market. Regarding public-private partnerships, there is a general view that they have not been effective in the past. Mechanisms for allocating funding were not considered to be sufficiently transparent and did not contribute to the development of the area. One successful example of a public private partnership is the Patto Territoriale dell'area Nord-Est which is a territorial pact for the north-east area of Naples that involves larger companies such as FIAT and Alenia. However this partnership is currently going through difficulties in relation to governance and financing. The distretti also seem to be facing challenges. This is particularly true for the textile districts of S. Giuseppe Vesuviano and S. Marco dei Cavoti.

Relatively recent initiatives relate to the Patti territoriali locali within the Piano del Lavoro, and to the Contratti di rete, which are focusing more closely on firms' networks. The basic feature of all initiatives is that they are bottom-up. There are not many large, hi-tech companies in the area and current initiatives suffer from a lack of coordination among very small firms which lack clear long-term strategies.

Tax credits, both from the national and the regional government, are the dominant policy tool to encourage investments in new technologies and productivity improvements in Campania. There was a move in 2007 to rationalise a rather chaotic system of state funding to firms, and further financial support has been offered in the wake of the financial crisis (conversion of short-term debt into medium-long term debt). Experts from outside the public sector are far from enthusiastic about the outcome of these policies.

\footnotetext{
${ }^{10}$ Borsa Lavoro, a national service, which was however substituted last year by a new system, ClicLavoro.
} 
There seems to be problems of rent-seeking and deadweight costs as firms that get subsidies for R\&D and innovation were likely to carry out these projects in the absence of funding. There has also been no evaluation of policy outcomes. Emphasis is on the number of firms reached rather than on the additional investments or R\&D expenditure generated.

There are examples of dynamic local systems in the large agri-food district of Nocera-Gragnano and the aerospace district which is focusing on Alenia, a large hi-tech, company originally created by the public sector. There are also a number of interesting projects which aim to improve skills formation and deployment among firms. Two such examples are: the Distretto Formativo from the agri-food district of Nocera-Gragnano and the Azienda Speciale per la Formazione from the Chamber of Commerce of the Salerno province. However, these are very recent initiatives and the evaluation of outcomes is not yet available.

Generally, it seems that there are not structured systems in place which disseminate information from the private sector about its skills needs. However in this regard, there are two initiatives that should be highlighted even though they are not fully implemented. Within the Piano del Lavoro (a regional law approved in 2010) there is a provision for a Tavolo Permanente di Concertazione, where social partners are supposed to draw maps that highlight regional skills needs. Within the Distretto Industriale Agrolimentare Nocera-Gragnano there is also a project for an Osservatorio Distrettuale to monitor skills needs, but this is currently experiencing funding problems.

\section{Veneto}

During the last four to five years, the Veneto economy has undergone a significant restructuring process that has been exacerbated by the current recession. This process has brought increases in firm size and the organisation of new firm networks and supply chains. However, these changes have not led to a significant increase in R\&D. Additionally, the role of ICT and new technologies is still marginal and there are often problems related to rent-seeking. The participation of the public sector in this process, either through state funding or otherwise, has been somewhat weak. Efforts have been made to help companies in the region to address the complex transition from a family-type management model to one that is more modern thanks to the efforts of Confindustria Veneto SIAV Spa. This service company was brought into existence in the early 1980s by the Veneto employers' association.

The Veneto economy is similar to the rest of Italy in terms of firm size, meaning that there are structural limits for the creation of high-quality jobs. The main problems affecting Veneto is the ineffectiveness of the public sector, a situation made worse by the lack of funding (funding of the public sector is not linked to the relatively thriving regional GDP per capita), and the existence of high entry costs. Newcomers may incur legal problems of various kinds, which are not dealt with satisfactorily by either the political or the judicial system. Similar to Campania, public-private partnerships have not done well in the past although there are some positive examples such as Veneto Nanotech. It is worth noting that labour relations are believed to be very good. Strikes are infrequent and there is a good cooperative relationship between social partners.

The Excelsior database is widely acknowledged for its unique role in the measurement of skills supply. As in Campania, there is a lack of quantitative policy assessments. Veneto is unique because its regional labour department (Veneto Lavoro) has constructed a very comprehensive database related to the labour market (including the so-called Borsino delle professioni), which gathers computer-based information from its job-centres.

There is a view in Veneto that the education system is capable of producing the amount of high-level professional skills demanded by firms. Until the current recession there was a perceived lack of technical 
skills and intermediate language skills. The Chamber of Commerce organised a business survey including questions about firms' skills needs. It emerged that more collaboration was needed between firms and the education system but views differ as to which of the two make more of an effort and on which training policies should be implemented. There is a general acknowledgement that in the wake of the financial crisis that more effort is needed to gear labour market interventions toward retraining the labour force. Public policies are severely constrained by lack of funding and lay-off schemes are not sufficiently used to promote training. Past performance and the current lack of funding suggest that successful policies in the future should be centred on simplification of administrative procedures and quicker implementation.

\section{Making comparisons: match between skills supply and demand}

Figures 13 and 14 support the view that Campania and Veneto are representative of the north-south divide. When normalising data vis-à-vis the country median value ${ }^{11}$, the Veneto provinces are either in the high-skills or in the skills-shortage quadrants. The Campania provinces are, on the other hand, in the lowskills or in the skills-surplus quadrants. Campania seems to be characterised by low levels of productivity regardless of its level of skills supply.

Figure 13. Skills supply and demand in Campania and Veneto, 2001

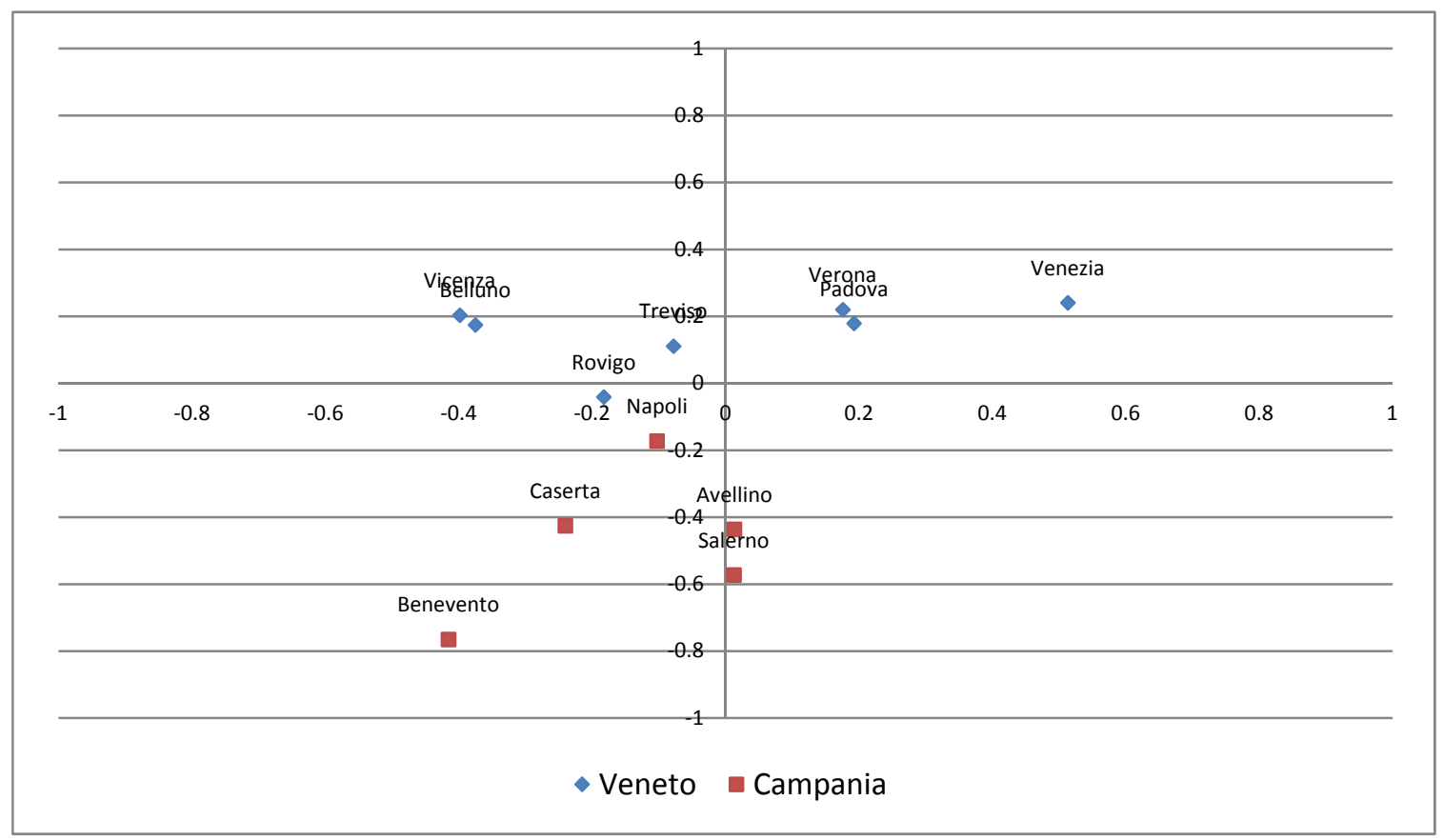

Source: own calculations on ISTAT data

\footnotetext{
${ }^{11}$ The representativeness of Campania and Veneto is validated by the MLM analysis. The lack of significance of their dummies suggests indeed that our regions of interest do not carry any idiosyncratic factor, which means that they can be deemed as representative on a national scale. Detailed results are presented in the Appendix, Section 3.3.
} 
Figure 14. Skills supply and demand in Campania and Veneto, 2009

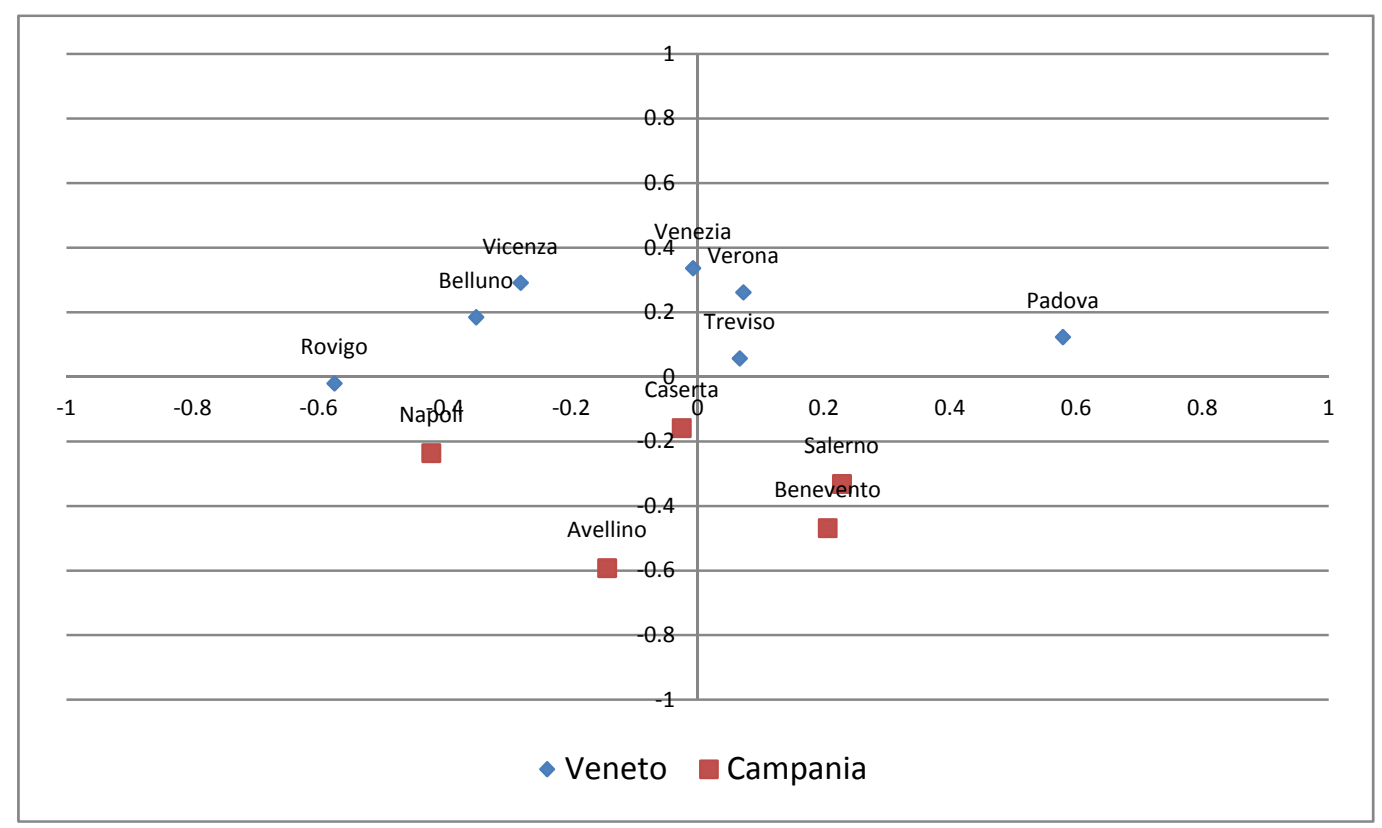

Source: own calculations on ISTAT data

\section{Findings for specific sectors}

Three sectors of interest - hides and skins; food, beverages and tobacco; hotels and restaurants - have been selected for further research in the two regions. Hides and skins (also referred to as hides) is a sector representative of "Made in Italy" products (see Box 4) - the leather industry still has the highest coefficient of localisation among manufacturers. Furthermore, both in Campania and in Veneto, there are districts that are highly specialised in this kind of production (i.e. Solofra and Arzignano).

Food, beverages and tobacco, and hotels and restaurants (also referred to as food and tourism) are also highly representative of the Italian economy, and are very widespread in both Campania and Veneto. Food and tourism allow a good comparison of the two regional economies, as it is representative at the national level and are not significantly affected by idiosyncratic factors. This point is validated in the Appendix both by the multi-level MLM (Section 3.3) and by the descriptive analysis presented in Section 5.1.

The lack of significance of their dummies in the Multinomial Logit Model analysis (with the partial exception of tourism for the skills-gap case) suggests that food and tourism do not carry any idiosyncratic factors. Food and tourism-based local employment systems (SLL's) are frequent in both regions, occupying similar positions in the value added per employee and employment rate rankings. The only difference is that tourism-based SLLs have a very high employment rate ranking in Campania and very low in Veneto. ${ }^{12}$

12 Sections 5.1.1 and 5.1.2 in the Appendix present the distribution of SLL by specialisation. These attributions are based on the sectoral classification proposed by Istat, with the exception of Venice and Verona, which were forcefully attributed respectively to the Tourism and Food sectors by various regional experts. 


\section{Box 4. Made in Italy}

Made in Italy refers to the process of revaluation of Italian industrial and handicraft production which has led Italian products to excel in international business, especially in the 1980s. Today Italy is the world's fifth largest manufacturing country in terms of manufacturing value added after the US, China, Japan and Germany. Italy is the second largest industrial manufacturing country in Europe after Germany.

The major sectors where Italian manufacturing is most specialised and has a substantial foreign trade surplus can be listed under the so-called "Made in Italy" sector or 4 Fs:

- $\quad$ Food and wines;

- $\quad$ Fashion: including apparel, leather goods, footwear, jewellery, eyewear, cosmetics and perfumery;

- Furniture and building materials: including wood products and furniture, ornamental stones, tiles and other ceramic products;

- $\quad$ Fabricated metal products and machinery, Ferrari cars, yachts, cruising ships and helicopters, plastic and rubber products: including all non-electronic machinery.

In traditional sectors (food, fashion and furniture) Italy is aiming towards the higher-value-added segments, thus distinguishing its production from the lower-value articles from emerging countries. At the same time fabricated metal products and machinery represent a number of sectors where Italy is a niche leader in technology and quality, with products ranging from luxury yachts to cruising ships, from Ferrari cars to helicopters, from specialized industrial machinery to general-purpose mechanical equipment such as valves, taps, pumps, from domestic appliances to metal household goods, knobs and handles, ironware, bolts, down to a wide range of plastic and rubber articles.

Source : Fortis M. (2009)

\section{Skills utilisation in firms}

In order to gain a better understanding of the obstacles and barriers to effective skills utilisation, and the current policies in place to address these issues, a questionnaire about skills formation and utilisation was distributed in Campania and Veneto to firms in the three sectors of interest.

The questionnaire was aligned along three basic axes: (a) the identification of employer skills needs (particularly skills shortages and gaps) (b) information about skills deployment and utilisation; and (c) the investigation of the perceived benefits of skills policies. The questionnaire was distributed to a sample of 30 (ten firms per sector), chosen on the ground of their representativeness. The response rate was high: 28 out of 30. The main results are listed below:

- $\quad$ There appeared to be some difficulties in finding technical skills among the labour force. This result was also confirmed by an e-questionnaire addressed to national level experts.

- There was low satisfaction with respect to the availability of technical education and training. The slow reaction of the public sector was often cited as the main cause.

- Firms devote fairly little time to training, and do not generally feel the need to invest in highperformance work practices. The lack of training is surprising because a considerable amount of the resources from labour taxation (paid by both employers and workers) is earmarked to finance training activities (and remains largely unspent). 
- Firms appeared wary of getting into formal partnership arrangements with the public sector. While they needed funding for R\&D and innovation they did not want to be tied down by commitments in relation to their activities. Firms also appeared reluctant to pass on information about their relationship with unions.

\section{Summary}

Most firms across the three sectors seem to have unmet demand for more technical ${ }^{13}$ and managerial skills and the public sector is not efficient in providing adequate support and training. This explains why firms are rather wary of getting into defined relationships with external bodies and organisations including unions. However, little appears to be done about skills utilisation by firms themselves. Firms devote fairly little time to training, and do not generally feel the need to invest in upgrading the skills of their employees. This can be partially explained by the existence of many temporary contracts and by the small size of Italian firms. Smaller employers see training as a cost and in general they are reluctant to invest in temporary workers.

In Campania, local firms are just one link in a complex international supply chain, and the extent of coordination among them is far from satisfactory (i.e. employers do not feel part of the local community or social fabric). This makes it difficult to evolve and use innovation as a mechanism to improve skills utilisation and job quality. In both regions, but especially in Campania, there is a rather bottom-up approach to coordination between private and public sectors, however, the actions of the public sector were not seen as optimal. Moreover, there is a lack of quantitative policy assessment, mainly due to the poor quality of data collected at the local level. There also tends to be an emphasis on procedures rather than outcomes.

\section{Local case studies}

Two local case studies were explored further in Veneto: the Brenta District and the Treviso Pact for local development. These areas both host small to medium sized firms, which aligns with the distribution of firm size at the national level

\section{The Brenta District}

The Riviera del Brenta industrial district (also referred to as the District) is located across from Venice and Padua provinces and centres upon the municipalities of Stra, Fiesso d'Artico, Fossò and Vigonovo. It is the world centre of production for high quality women's footwear which is used by major international fashion brands to produce and design leather accessories. The district's beginnings date back to 1898 when Giovanni Luigi Voltan created the first industrial shoe company in Italy, drawing on his experience gained working in the footwear industry in the United States. Various spin-offs and newly created companies (most of which were created by former Voltan employees) formed in the early twentieth century, expanding production of industrial footwear using their accumulated knowledge built over centuries by local shoemakers and cobblers. These workers spread technical knowledge and industrial culture creating networks between people and businesses.

Brenta producers were able to bring a traditional craftsman's mindset to industrial production using new technology to satisfy diversified demand. This process of converting informal networks into knowledge, and vice versa, was supported by the School of Arts and Crafts Ottorino Tombolan Fava, created in 1923 for professional training in various crafts and then eventually specialising as a school for footwear designers. This training institution, and its successor the Politecnico Calzaturiero, played a key

\footnotetext{
${ }^{13}$ Technical and professional skills are those skills that are specific to a particular sector, profession or trade
} 
role in the transition to higher-added value activities, becoming an essential component of the competitive advantage of the district.

\section{Box 5. The Riveria del Brenta: Facts and Figures}

\section{- 591 small-medium firms covering the whole supply chain}

- 149 shoe manufactures

- 329 sub-contractors - producing accessories and components,

- 62 designer firms and studios

- 51 trading companies

- 10624 workers

- 6991 employed in shoe manufacturing

- 1928 employed in sub-contractors - producing accessories and components

- 254 employed in designer firms and studios

- 241 employed in trading companies

- 1210 owners and partners

- $\quad 19.83$ million EUR luxury or top-of-the range shoes annual output

- $\quad$ Turnover is greater than EUR 1.65 billion

- $91 \%$ of the production is for export

- Mainly small-medium firms. $75 \%$ are firms with less than 50 workers

- The extent of international outsourcing of production, although growing, is less pronounced than in other industrial districts

Source : ACRIB

The district now has a strong concentration of manufacturers of top women's designer footwear, which draw on the expertise, knowledge and skills of the local workforce. Shoes are handmade and labour presents about $40 \%$ of production costs because the manufacturing processes is not fully automated. A very important role is played by the mounters - who are workers generally without formal training.

While 1950-85 saw world markets dominated by medium-high quality products, 1985-95 saw a repositioning of the market to favour luxury goods and in particular top brands. During this period the Brenta District lost its traditional 'medium quality' markets in northern Europe. About 50\% of manufacturers chose to reposition their business towards the luxury market where the additional profit margin would allow them to absorb higher production costs. The remaining $50 \%$ chose a different strategy, which meant they had to move production to countries with low labour costs. This choice was guided by informal discussions and decisions made by the company's boards of directors. Trade unions were not part of these boards but met with them regularly. Frequent discussions led to a series industrial policies and joint management agreements. This process led to a drastic rise in the importance of non-manufacturing related services as seen in the growing share of high-skilled employees in $R \& D$, management and marketing. Before this adjustment, almost all workers in shoe manufacturing were blue collar workers 
while nowadays this proportion is around $40 \%$ (the other $60 \%$ is divided between staff designers (50\%) and commercial staff (10\%)). The local training institution, the Politecnico has been absolutely crucial in the management of this transformation.

\section{The institutions: an overview}

The role of informal institutions, such as cultural associations, within the region has been highlighted as an important component of competitiveness (Becattini, 2004). Speaking the same dialect, living in the same territory, meeting in bars, in church, and in recreational centres promotes the spillover of information and represents the foundation of a community. The spillover of information and knowledge, the ability to work informally and the appropriate division of labour among companies are all important characteristics of the Italian industrial district. However, while informal institutions have a role in a region's competitiveness, the existence and impact of a number of formal institutions are critical in the case of the Brenta district.

ACRIB

ACRIB is the main formal institution of the district. It was created in 1961 because there was a need for representation on behalf of business to bargain wages with unions across the two provinces of Padua and Venice. Additionally, an organisation was needed to manage the participation of a number of smallmedium firms at international trade events. Over time ACRIB has become a hub for business, while maintaining its role in negotiating with unions. ACRIB is part of ANCI, the National Association of Italian Footwear Manufacturers, and has a delegation in the Industrial Associations of Vicenza, Padua and Venice. Its main activities include negotiating with the trade unions, providing advice on economic and fiscal issues, and dealing with communications and media on behalf of businesses in the district.

It plays an important role in disseminating information and knowledge in the district and has the following goals:

- A dynamic system of firms able to innovate and expand;

- Well-trained and cultured workers, capable of adapting to changes brought about by market forces;

- Group leaders capable of social and political representation that can predict and guide various kinds of developments;

- A functional infrastructure system;

- A flexible public sector, attentive to the needs and problems of the producers. 


\section{The Politecnico}

In 1986, the Consorzio Centro Veneto Calzaturiero - Politecnico Calzaturiero was set up mainly for the purposes of professional training (scuola per modellisti). In 2001, this institution became the Politecnico Calzaturiero, a private company started by the National Association of Italian Footwear Manufacturers (ACRIB), the National Association of municipalities (ANCI), Veneto Innovazione and the public and private bodies of the Veneto region to promote initiatives in training, research and technological transfer as well as the development of quality and safety at work. The Politecnico operates in partnership to build an integrated network to support firms throughout the supply chain.

The Politecnico Calzaturiero inherits a tradition that has its origins in the Scuola di disegno per arti $e$ mestieri (Design School for Arts and Trade) that settled in Stra in 1923 to later become the Scuola di design e Tecnologia della calzatura (School of Shoe Design and Technology). The activities of the Politecnico Calzaturiero are quite unique, not only in Veneto but also across the rest of Italy. It is along with Polimoda in Florence and SCAM in Civitanova Marche, part of the Rete Nazionale dei Centri di Eccellenza (National Network of Excellence Centres), created by the Associazione Nazionale Calzaturifici Italiani (ANCI), for training in the footwear sector.

Its activities are characterised by a mix of four distinctive elements that cannot be found in other training schools:

- $\quad$ Tradition - the Politecnico has received wide national and international recognition in its 80 year history. It has contributed to the training most of the entrepreneurs, designers and shoe technicians that are working in the Region today;

- Cooperation with footwear companies - the synergy with ACRIB is vital to promote company development and growth;

- Composition of the teaching staff - entrepreneurs, stylists, designers, experts and consultants working in shoe companies make up most of the teaching staff;

- Integration of training with the other activities - services are offered for technological research and quality control of the materials used in shoe making.

Training, technological research and quality teaching need good infrastructure. Its building contains eight classrooms for traditional teaching and practical exercises; two IT laboratories with 32 workstations equipped with internet connections, software for office automation and 2D and 3D CAD design, a quality control laboratory, a laboratory for cutting and blinding, a library and two conference rooms.

Teaching themes are decided by the school committee, following ad hoc surveys. The Politecnico also undertakes research projects, including research actions within the European Social Fund. It operates through a network of partnerships and its activities concentrate on the development of the following areas:

Training: The principal mission of the Politecnico is the training of entrepreneurs, managers, young people and new graduates, involving on average 1000 pupils, 100 teachers, 10000 teaching hours divided into about 100 different courses each year. Activities include taking part in experimental training using new distant-learning technologies, organising courses on the use of new technologies and being involved in vocational guidance. The Politecnico is part of a network of schools that, through the RISPOSTE project sponsored by Regione Veneto, provide new guidance techniques. It also takes part in international projects that harmonise teaching programmes for the training of professionals working in the fashion sector and is promoting training initiatives for the footwear sector involving higher education institutions.It organises 
training projects for unemployed young people in co-operation with the training of Confindustria in the sphere of ESF initiatives, which involves working together with temporary employment agencies. It works together with the Provincia di Padua and with IRECOOP to organise training to introduce disadvantaged people to work. Specialist management courses are provided for the footwear sector in addition to workshops for employers.

Technological Innovation: The Politecnico promotes and participates in numerous research and technology transfer initiatives in Italy and abroad. Collaboration with major universities and leading manufacturers is undertaken for the development of processes, products and innovative materials. The Politecnico also carries out research aimed at developing human resources. For example, it sponsors sector studies in co-operation with universities in order to develop and design new production technologies and tests new technologies in co-operation with machinery manufacturers and CAD-CAM systems. It cooperates with the most important producers of machinery for the shoe sector and with the CNR-ITIA Research Centre in Milano and Enea in Bologna for the realisation of projects developing new technologies for the footwear sector. The Politecnico offers a range of services designed to meet the specific needs of footwear companies, including standardised catalogue activities and personalised interventions.

Quality Control and Control of Materials: In this area, the Politecnico offers a laboratory and quality control of materials for companies in the Veneto region. It tests new materials used in the footwear sector and promotes projects for the implementation of European regulations on quality system certification in footwear companies.

Safety in the Workplace and Equipment: In this area, the Politecnico deals with the study and application of laws and regulations in force contributing to the education of footwear companies on environmentally friendly practices. It helps companies with the implementation of these regulations, carries out quality and quantity environmental analysis as well as organising training courses for security staff.

\section{The Unions}

An important feature of ACRIB's activity is its long standing relationship with the trade unions. There is a tradition of tripartite dialogue which dates back to the creation of ACRIB. On 24 February 1962, a Accordo Zonale (Territorial Agreement) was concluded, which broke the rigid Confindustria patterns of territorial organisation by bringing all firms together from Venice and Padua into one single organisation with a view to creating a united strategy in wage bargaining while at the same time building their access to world markets. The local trade unions were initially not pleased by this strategy because they were used to negotiating on an individual firm basis, which meant that they could leverage concessions from previous negotiations to get more in the bargaining process. However they gradually began to realize that the new system was essential for organisational growth, especially for understanding global processes that go beyond administrative (province) boundaries. Thus, the 1962 Territorial Agreement was a win-win. There were periods of conflict as well as those of relative co-operation, but both employers and workers shared a common responsibility and understood the importance of ensuring the future of the District.

Recent agreements have acknowledged the importance of the skilled labour force. These agreements have been concerned with creating a dynamic system that is able to innovate and expand; produce welltrained workers who are capable of adapting to changes brought about by wider market forces. Initially the key points of the agreements were procedures for granting the Premio di vantaggio (an extra wage month) rewarding productivity increases. High priority was also given to regulating working from home (mainly for female labour), in order to reconcile flexible working hours with family and other personal 
requirements as well as health and safety regulations. The district has the lowest rate of accidents in Italy as certified by figures from the Italian Workers' Compensation Authority.

A new important development occurred with the agreement of February 28, 2000, which draws an explicit link with the Patto territoriale della Riviera del Brenta (territorial pact of the Riviera del Brenta). Emphasis was placed on the role of the public sector for the district's development as well as the need for appropriate political representation of producers. Two infrastructure projects are planned: a) the wiring of the district; and b) the setting-up of a Città della Moda, a "Fashion City". Other priorities include undertaking the quality certification of the District's companies, and setting up better organisation for training and technological research with the request to extend training projects to lay-off periods (Cassa Integrazione Guadagni). An agreement concluded in February 2004 outlined strategic goals, including commitments in the field of innovation and lifelong learning. These have been two recurring themes in the Brenta district and were finally outlined in an action plan.

The current recession has deepened the relationship between the ACRIB and unions within the Consulta territoriale - Territorial Council. Along with the premio di vantaggio, the Consulta regulates price standards and production times for the whole district. The Consulta was established with the purposes of combining the monitoring of labour laws, the construction of joint development strategies on innovation and $R \& D$, social inclusion, integration of migrant workers, flexible working hours and work organisation. It includes ACRIB, Confindustria, Confartigianato and union representatives.

\section{Box 6. ACRIB Servizi Srl}

ACRIB's private service company, ACRIB Servizi Srl, was founded in 1999 after over 40 years experience in services and initiatives for the shoe-making sector. One of its main activities is the provision of research and implementation of individual projects and initiatives, offering specialist services in order to promote, support and develop initiatives with regards to domestic and export trade. It also organises events, conventions, promotions and competitions, information services, consultancy and support "on demand". It also coordinates and manages innovative projects at the European level.

Source : ACRIB

\section{Summary}

In sum, the Voltan brand initially had a distinctive imprint on the Riviera del Brenta region, creating networks between people and businesses, as well as favouring a distinctive mix between informal knowledge accumulated in the local area and modern industrial culture. The creation of the School of Arts and Crafts Ottorino Tombolan Fava, critically supported the interaction between formal and work-related knowledge, finally becoming internationally known as Politecnico Calzaturiero. Third, and probably more importantly, there was the creation of ACRIB in 1961. What was most distinctive about ACRIB was that it brought together firms from the provinces of Venice and Padua into one single organisation (both in terms of the organisation of union activities and marketing). While it originated from the need to avoid wage conflict with local trade unions from each province, it soon became a co-operative mechanism uniting employers and workers.

While the District has faced challenges during the current recession, on the whole, there is no doubt that it is a success story. What is remarkable is that it is a story about highly successful product innovation, enacted by a network of fairly small firms. Moreover, one of the success factors relates to the interaction between skills formation and deployment, mirroring the close interaction between ACRIB and the Politecnico. 
The flexibility shown by the Politecnico in accommodating and sometimes anticipating skills demand from the district will continue to be important as the region adapts to future global change. It also offers important lessons for skills-led local development in other parts of Italy. However, one of the challenges for the district relates to the weak role played by public policies and especially by local public institutions. It is clear that ACRIB and the local unions felt that it was necessary to complement and, to some extent, surrogate local public institutions by establishing their own territorial council. The local Territorial Pact could also do more to elicit public-private interaction in the region.

\section{The Treviso Pact}

The economy of the Treviso province

In the first post-war census of 1951, the industrialisation of the entire Treviso province was fragile, characterised by an economy still largely tied to agriculture. More than half the population worked in agriculture, while only 31\% was in industry and tertiary. Between the 1950 and 1970, the make-up of the province's economy changed. More than half of the active population worked in industry and manufacturing, while agriculture workers made up only $16 \%$ of the workforce. The province has gradually become one covered by a dense network of productive activities, consisting primarily of small-medium manufacturing firms. From being a province of emigrants, it has also become a land of immigration. Moreover, entrepreneurial initiatives and investments are multiplying, thereby increasing the demand for skilled labour.

The sectors that have seen the most growth are textile and clothing, metal, food, wood (furniture) and footwear. In the 1980s, the province entered a post-industrial stage of development, with the majority of the working population employed in the services sector rather than manufacturing. Despite this, local manufacturing continues be central to the provincial economy and almost $50 \%$ of the income produced in the province comes from the secondary sector. The economic strength of the province is shown from the data in box 7. 
Box 7. The Treviso province, facts and figures, 2009

Population

Resident population

863000

Active population

408000

Immigrant legal residents

78000 (9.1\% of the population)

\section{Employment}

Total employment

Activity rate (15-64)

$70.3 \%$

Unemployment rate

Female activity rate

$59.4 \%$

Employment by sector:

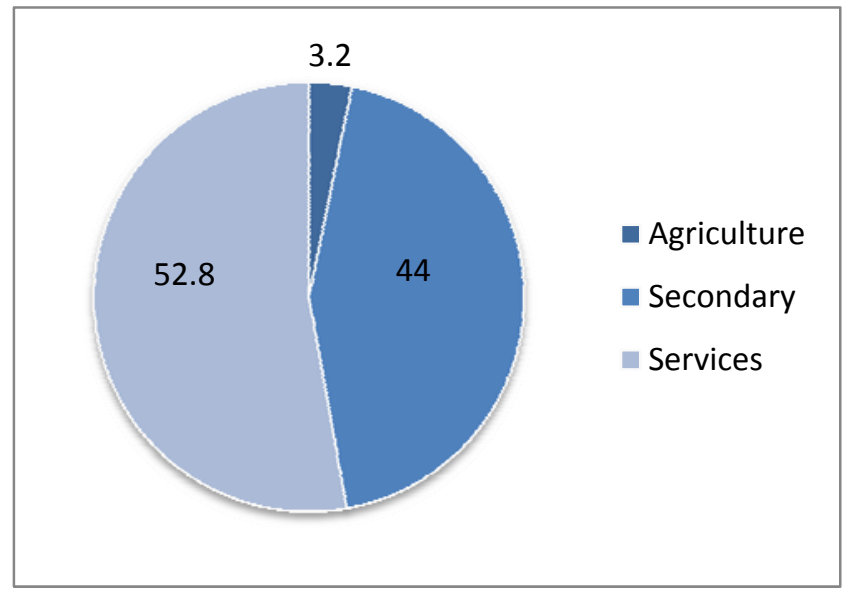

Industry

Activity companies 85,184 (of which $15.3 \%$ manufacturing)

Rate of openness (export + import / GDP) 68.1\%

Exports 10.273 billion euros (2007)

Imports 5.97 billion euros (2007)

Balance imports /exports 4.3 (2007)

GDP 26.08 billion euros in 2007

GDP per capita 30,218 euros (2007

(+ $17 \%$ of national average)

Source : Istat

A very important element in the recent evolution of the Treviso economy has been the outsourcing of manufacturing activities to Eastern Europe, especially to Romania and China. In the last decade, 
outsourcing has resulted in a large amount of job losses. In 2004, a first local pact for growth and industry among unions and the local Confederation of industries was implemented, becoming the so-called Strategic Pact for the Province of Treviso. The main aim of that pact was to reintegrate workers that had lost jobs because of lay-offs back into the labour market. This proved quite difficult, even though the main unions (CGIL, CISL, UIL) asked for support from various local institutions, including the Chamber of Commerce. It has become clear that, especially for women, youth and older workers, re-entering the labour market and securing good quality work can be quite difficult. These problems have become even more serious with the current recession, resulting in the signing of a new pact for sustainable development and job creation in 2011 - Patto per lo sviluppo sostenibile, la qualificazione dell'occupazione, la competitività del sistema economico locale - between unions and the local Confederation of industries (also referred to as the Pact).

\section{The new pact for sustainable development and job creation}

The Pact was signed in 2011 by unions and the local Confederation of industries of the Treviso province, with a view to establishing a closer relationship to meet the needs of the area and develop policies of mutual interest. ${ }^{14}$

The Pact aims to map the economic and social transformations under way and develop closer relationships between business and labour aligned to the needs of the area. Its ultimate goal is to provide benefits to the local community by protecting local interests and avoiding the negative externalities associated with industrial conflict. The Pact places a strong emphasis on second-level wage bargaining (over and above the national one) negotiated at the provincial level. In the absence of second-level bargaining at the company level, wage negotiations would be carried out across SMEs in the province belonging to the same industrial sector. The Pact attempts to make SMEs in Treviso more competitive, providing at the same time higher rewards for more skilled and productive workers. In an area where the share of temporary workers has recently doubled, the Pact aims to provide an environment favouring better skills utilisation and a more stable employment relationship.

In Treviso, the system of two-level bargaining on a provincial basis was adopted following the successful experiences in the wood industry of Pordenone (Pordenone is a heavily industrialised province in nearby Friuli). Now in Pordenone, the system is being extended to all other industries. The system is based on linking wage growth to a set of parameters. At the beginning of each year, firms choose two or three of these parameters which are most appropriate to their situation, communicate them to unions and at the end of the year, if the parameters are met, wages increase. The pattern of the two agreements, which are very similar in spirit if not in detail, is simple. The social partners recognise each other -and build consensus on two-level bargaining, to sustain the competitiveness of firms' and interact with local institutions jointly to facilitate and aid economic recovery plans.

CGIL, CISL, UIL and the local employer associations talk about tangible tax relief for the payroll meaning there is an effort to build recognisable and shared criteria for the variable part of wages. This creates a (relatively innovative) industrial relations system with a territorial basis, which decisively enriches the two-level bargaining system established by the 1993 Agreement. This effort, although being consistent with recent government efforts to experiment with territorially-based agreements, goes beyond the government emphasis on tax relief for production premia and overtime.

\footnotetext{
${ }^{14}$ The Italian text of the Pact can be downloaded from: http://www.treviso.cgil.it/comunicati/patto_per_lo\%20SVILUPPO_7-02-2011.pdf
} 
The Pact is innovative in its method more than in its content. A sustained and proactive attitude was instrumental to reaching an agreement that included all unions and the confederation of industries, contrary to what often happens at the national level. Furthermore, the effectiveness of the agreement and its duration are bound to a safeguard clause. The Pact, effective only after ratification by all signatory organisations, will last two years from the date of ratification submitted by the last party that approves it. At any time the parties are able to communicate a unilateral suspension or cancellation of the Pact.

In the cases of Pordenone and Treviso, as well as of Luxottica (the large glass-making company from Belluno), trade unions and employers recognise each other as interlocutors of stable industrial relations. Unions recognise firms' organisational autonomy and clarify what is meant by redistribution and participation in company results. They have abandoned the notion that one should always negotiate on everything and accepted that a firms' organisational autonomy should be recognised as legitimate for the sake of its efficiency.

In the case of Luxottica's participation, company results happen through a combination of reward system and corporate welfare in the Pacts of Pordenone and Treviso through the provision of a system of territorially-based wage integration. In fact, plant-level bargaining can be implemented in a rather straightforward manner in large companies such as Luxottica. On the other hand, when there are many small-medium firms, like in Treviso or Pordenone, or in most of the national territory, second-level bargaining necessitates the implementation of an agreement binding together unions and firms of the whole area.

However, the relationship between employers associations and unions is a "necessary but not sufficient" condition to ensure the development of the province. Indeed, the Treviso unions are willing to use the Pact as a springboard for more active labour market policies, a leaner and more effective bureaucracy, less labour taxation, streamlining the levels of political representation, the construction of a functional infrastructure system and the development of an interprovincial vision (the last point brings to mind the effort already made by ACRIB 50 years ago).

\section{Brenta district and the Pact - similarities and differences}

It is instructive to consider the Pact in light of some of its similarities and differences with the Brenta District. First of all, it is important to stress that both build on networks of relatively small firms and elaborate creatively on the two-tier bargaining system as originated by the 1993 Agreement without superseding it. In this sense, they both demonstrate that important institutional progress can be made in Italy within the current institutional arrangements. The Pact also shows that a strategy among employers as well as unions can be developed across diverse industries and outside of a single sector.

In both Campania and Veneto it appears that firms or sectors which do not have a satisfactory niche in the international market, and are engaged in the production of fairly standardised goods, have been heavily penalised by recent trends (i.e. globalisation and the recent financial crisis) and are not likely to improve their skills utilisation in the future. On the other hand, skills appear to be best supplied, developed and utilised through collective stakeholder action, elicited by cohesive employer associations (i.e. ACRIB). In the presence of such coordination among employers, providing them with extra clout and strategic capacity, sustainable local skills ecosystems may evolve even if diverse aspects of the supply chain are located in different areas. 


\section{POLICY CONCLUSIONS}

The policy review and the interviews conducted with national and regional policy experts have made it clear that in Italy, most policies at the national and territorial level have been traditionally focused on skills supply rather than skills demand. Only recently and on a relatively small scale have resources have been devoted to subsidising R\&D and innovation. In both Campania and Veneto, but especially in Campania, there is a rather bottom-up approach to interaction between the private and public sectors. In the past, the actions of the public sector have not had a very good record, and these efforts have been made worse by a general lack of quantitative policy evaluation. In this sense, policy evaluations have focused on procedures rather than on outcomes.

\section{Skills formation and supply}

In general, the employers consulted for this study were not particularly favourable in relation to the supply of vocational training in Italy, with the main issue being that training curricula are overly bureaucratic and centralised. It is true that local employers' associations and chambers of commerce can lobby and use regional funding to adapt training to local needs. However, there is currently an underutilisation of training funds. To some extent, government, unions and employers are trying to blame each other for this situation but in many cases, firms do not provide training due to the lack of flexibility in course design, the existence of high transaction costs (i.e. red tape) and the lack of information about available funds (see on this Brunello et al., 2003). The flexibility shown by the Politecnico Calzaturiero of the Brenta district in accommodating and sometimes anticipating skills demand from the district's firms is thus a very important lesson in relation to skills formation. This study has also highlighted the potential role played by employers' associations in bringing together micro and small firms to articulate skills needs to local and national governments.

\section{Matching}

Limited policy attention is paid in Italy to promoting a supply-demand balance. Indeed, the 2010 Labour Plan from the Ministry of Labour, announced that Italy, more than other countries, has a mismatch between labour demand and supply, and blames the "total inadequacy of the training system" rather than the lack of a robust socio-economic infrastructure able to bring together workers and jobs. Expenditures for public employment services are low, in part because there is no unemployment benefit system. This means that, among other things, employment agencies have no stringent requirement to engage in effective actions to support the unemployed. Yet, even without a significant reform of the system, it is still possible to improve the monitoring and evaluation of public employment services and implement various policy interventions relating to skills formation and deployment. For instance, public employment services could target unemployed youth and link them to appropriate training services of various public and private bodies ranging from public schools to temporary work agencies. These bodies should be accountable to the public employment service and their activities should be monitored and evaluated. More funding should be given in the short-term to support the geographical mobility of workers. Commuting to work over long distances deserves special attention in this area. 


\section{Skills demand and utilisation}

Besides supporting innovation and R\&D using public finances, it is necessary to respond to firms' needs regarding skills demand and supply in a more efficient way. For instance, Act 236/1993, which contains the main policy tool for lifelong learning and which is also geared to retraining interventions, was implemented in 1996, three years after its approval by the Italian parliament. A law introduced in 2006 was only financed in 2009. An additional problem, which is related to the tax credit scheme, was sorting out the huge amount of applications which accumulated over the time span between implementation and actual financing. In order to deal with this backlog, a procedure (based on the arrival time of the on-line applications to the Ministry's offices) was adopted, which did not result in a thorough application selection process.

A related point is that proper policy evaluation is seldom carried out in Italy. Policy makers are very interested in the relationship between available and spent funds (especially those coming from the EU), but fail to monitor the impact of funding on firm behaviour. Finally, while there seems to be a decisive role for the ESFs, many experts suggest that coordination among national and regional interventions is difficult to achieve. Research carried out for the Skills for Competitiveness project supports this finding, especially for Campania. The research for this project has also made clear that the distretti are currently far from being the successful example of the past decades. A province having a strong presence of distretti was not found to be more likely to be in a high-skills equilibrium. It is important to note that even if the Brenta district still enjoys remarkable success, the story is different for other distretti in Veneto. In Campania the few distretti are facing significant challenges.

The lack of focus on skills utilisation may also find its origin in the 'work first' mode of unions and government. With increases in unemployment after the economic downturn, new initiatives have focused more on skills acquisition and the reintegration of the unemployed rather than on skills utilisation. It has been repeatedly pointed out that in the absence of cohesive employers' associations, a consistent approach to meeting skills demand is unlikely to be developed because of the many micro and small employers characterising the Italian economy.

Economic theory on labour market governance suggests that the presence of firm-level bargaining is an important precondition for a strong relationship between productivity and wages to increase workers' collective role in product innovation, and for the efficient determination of wages. It is also the starting point for recognising the proactive role of workers. For these reasons the Treviso Pact, as well as the long tradition of agreements between ACRIB and the local unions are very important examples. Firm size is certainly a limiting factor for the application of second-level bargaining in Italy. The initiatives reviewed in the case studies, relying upon firms' networks and territorial bargains, should be considered an interesting example for other areas of Italy.

In countries where wage negotiations are decentralised, firms innovate and hire adequately skilled workers from the labour market generally at a higher wage rate. Conversely, in a centralised wage bargaining system, wages are generally lower and firms, despite finding it more difficult to attract skilled workers from outside, gain from training their own workers. In such a situation, it also pays to promote coordination among employers and promote practices banning poaching (Blinder and Krueger, 1996; Casper et al., 1999). When considering the social advantages and difficulties of implementing training provided by firms, it is important to keep in mind that the right industrial relations system is a key variable (Warhurst and Findlay, 2011). Hence, if an effort is made to promote on the job training, it is important to encourage employer coordination as well. The Brenta district appears to be a good example of this principle, as the coordination of employment is accompanied by training provided by a socialised structure - the Politecnico. 
Finally, it should be stressed that even proactive behaviour from employers may not solve all problems. Employers may misjudge the kind of skills they need. Especially in family run businesses, existing skills related to traditional ways of working tend to be emphasised, instead of developing new skills useful for current or future labour markets.

\section{A role for public policy?}

A final lesson demonstrated by the Brenta and Treviso case studies relates to the role of local public institutions in supporting collaboration among social partners. It would appear that more decentralisation helps to achieve a closer relationship between local public authorities and local development (for instance, through more flexible and quicker-to-adjust training or R\&D incentives). Various experts (see Mauro and Pigliaru, 2011) have suggested that when social capital is scarce in a given area, giving more flexibility to local public authorities may lead to rent-seeking rather than to more proactive behaviour. More decentralisation could help areas already in the high skills equilibrium to grow more and to improve their labour-market performance, but may not help areas in the low skills quadrant, with possibly unfavourable effects upon the system as a whole.

Further reflection suggests that the public sector can in any case play an important role in providing more information at a territorially disaggregated level. In Italy, the Skills for Competitiveness research was well received by many stakeholders because it highlighted the need for more detailed information on skills at the local level. Various options could be considered by Italy for obtaining new data. In the short-term, the most feasible relates to the utilisation of the CNEL archive about national and decentralised bargaining in order to utilise its information about skills utilisation practices embedded in second-level labour contracts. Also, data on vacancies collected by ISAE and ISFOL-CSA (see Destefanis and Fonseca, 2007), which are in danger of being dismantled, provide a unique source of consistent time-series indicators of local demand for skilled and unskilled labour. In the future, the possibility to combine these data sets with the statistical information from Excelsior should also be carefully considered.

Reconciliation of a more flexible and decentralised public sector with some control over rent-seeking practices could be pursued by finding a new and stronger role for the public employment service at the local level. Local employment agencies are likely to have highly disaggregated information upon which to develop and implement policies. They are also less likely to be influenced by political vagaries compared to current state funding to firms especially if monitored by the central government and made accountable. Some interesting good practices, such as the Maison de l'Emploi et de la Formation in Mulhouse, France, as well as the establishment of one-stop job centres in the US should be considered, (see Froy and Giguère, 2010a, 2010b). 


\section{REFERENCES}

Acocella N., Leoni R. (2010), La riforma della contrattazione redistribuzione perversa o produzione di reddito, Rivista Italiana degli Economisti, n. 2.

Adam P., Canziani P. (1998) ‘Partial De-regulation: Fixed-term Contracts in Italy and Spain’, CEP DP No. 386, LSE, London.

Afonso A., M. St. Aubyn (2006), Cross-country efficiency of secondary education provision: a semiparametric analysis with non-discretionary inputs, Economic Modelling, 23, 476-491.

Allen K., Stevenson A, 1974, An Introduction to the Italian Economy, Martin Robertsn, London.

Amendola A., E. Rustichelli (eds.), (2005), Rapporto sul mercato del lavoro nel Mezzogiorno, ISFOL, Monografie sul Mercato del lavoro e le politiche per l'impiego, n. 12, Roma.

Banca d’Italia (2006), Relazione del Governatore.

Barba Navaretti G., Bugamelli M., Faini R., Schivardi F. e A. Tucci, A. (2007), Le imprese e la specializzazione produttiva dell'Italia. Dal macrodeclino alla microcrescita, Rapporto preparato per conto della Fondazione Rodolfo Debenedetti per il convegno 'I vantaggi dell'Italia', Roma, 22 marzo.

Becattini G. (2004), Industrial districts: A new approach to industrial change, Edward Elgar, Cheltenam, UK.

Blinder, A. and A. Krueger (1996), Labor Turnover in the USA and Japan: A Tale of Two Countries, Pacific Economic Review, 1, 27-57.

Brandolini A., Casadio P., Cipollone P., Magnani M., Rosolia A., Torrini R. (2007), Employment Growth in Italy in the 1990s: Institutional Arrangements and Market Forces, In Acocella N., Leoni R. (eds.), Social Pacts, Employment and Growth, Physica,-Verlag, Heidelberg.

Brunello G., Neirotti P., Paolucci E., 2003, Imprese e formazione, http://www.lavoce.info/articoli/pagina516.html.

Brunello, G. Comi S., Sonedda D., 2010, Training Subsidies and the Wage Returns to Continuing Vocational Training: Evidence from Italian Regions, IZA DP 4861.

Burriell Lombart, P., 2004, "An economic analysis of education externalities in the matching process of UK regions (1992-99)," Banco de España Working Papers 0403.

Buti M., Pench L., Sestito P. (1998), European unemployment: contending theories and institutional complexity, DGII, wp n. 81, Brussels.

Casper, S. Lehrer, M. and D. Soskice (1999), Can High-Technology Industries Prosper in Germany? Institutional Frameworks and the Evolution of the German Software and Biotechnology Industries, Industry and Innovation, 6, 5-24.

Cedefop, 2011, What next for skills on the European labour market?, Briefing Note, February 
Ciccone A., Cingano, F. e P. Cipollone (2006), “The Private and Social Return to Schooling in Italy”, Temi di discussione, Banca d'Italia , n. 569.

Coyle D. (2001), Paradoxes of Prosperity. Why The New capitalism Benefits All, Norton, New York

Daveri F., C. Jona-Lasinio (2005), "Italy’s Decline: Getting the Facts Right", IGIER Working Paper, n. 301.

Destefanis S., Fonseca R., 2007, Matching Efficiency and Labour Market Reform in Italy: A Macroeconometric Assessment, Labour.

Dotti N.F., Fratesi U., Lenzi C., Percoco M. (2010), Local labour markets and the interregional mobility of Italian university students, AISRE

Ebbinghaus B., Visser J., 2000, Trade Unions in Europe since 1945, Macmillan/Palgrave, London.

Ederer P. (2006). “Innovation at Work: The European Human Capital Index”. Policy Brief: The Lisbon Council, Bruxelles.

Fondazione ISTUD (2008), Districts and District firms: their evolution and future Developments

Fortis M. (2009), Competitiveness and export performance of Italy (Speech by Marco Fortis, responsible for the Economical Studies Department of Edison and vice chairman of Edison Foundation, at the meeting on "Italy's external competitiveness" organized by the Finance Ministry)

Froy F., Giguère S., Hofer A. (Eds.), (2009), Designing Local Skills Strategies, LEED, OECD, Paris.

Froy F., Giguère S. (2010a), Putting in Place Jobs that Last, LEED, OECD, Paris

Froy F., Giguère S. (2010b), Breaking out of Policy Silos: Doing More with Less, LEED, OECD, Paris

Furman J.L, Porter M.E., Stern S. (2002), “The determinants of national innovative capacity”, Research Policy, 31, 899-933.

Green A E, Hasluck C, Hogarth T, Reynolds C. (2003) "East Midlands FRESA Targets Project - Final Report”, Report for East Midlands Development Agency, Institute for Employment Research, University of Warwick, and Pera.

Hernanz, V., Toharia, L. (2006), Do temporary contracts increase work accidents? A microeconometric comparison between Italy and Spain, Labour, 20, 475-504.

Isfol (2011), Programma LEED OCSE “Skills for Competitiveness” Background Report, Rome.

Inps, 2009, Monitoraggio Regionale. Rome

Intesa San Paolo (2011), Monitor dei distretti, Servizio Studi e Ricerche, Marzo.

Istat, 2006, Rapporto Annuale, Rome.

Iuzzolino G., 2009, I divari territoriali di sviluppo in Italia nel confronto internazionale, in Mezzogiorno e politiche regionali, Cannari L., Iuzzolino G. (eds.), Banca d'Italia, Rome. 
Kim S. (1989), Labor specialization and the extent of the market, Journal of Political Economy, 98, 692705.

Kim S. (1990), Labor heterogeneity, wage bargaining and agglomeration economies, Journal of Urban Economics, 28, 160-177.

Kim S., Mohtadi H. (1992), Labor specialization and endogenous growth, American Economic Review, 82, 404-408.

Mauro L., Pigliaru F. (2011), Social capital, institutions and growth: further lessons from the Italian regional divide, CRENOS wp n. 11-03.

Ministero del Lavoro (2008), Rapporto di monitoraggio delle politiche occupazionali e del lavoro, Rome.

Ocampo J.A. (2002), Small Economies in the Face of Globalisation, Third William G. Demas Memorial Lecture at the Caribbean Development Bank

OECD, 2005a, Employment Outlook, Paris.

OECD, 2005b, Education at a Glance, Paris

OECD, 2011a, Education at a Glance, Paris

OECD, 2011b, Employment Outlook, Paris.

Pagano P., Schivardi F. (2003), "Firm Size Distribution and Growth," Scandinavian Journal of Economics, 105, 255-271.

Pirrone S., Sestito P. (2008), I disoccupati in Italia, il Mulino, Bologna.

Rossi S. (2006), La regina e il cavallo, Laterza, Bari.

Salvati M., 1980, Alle origini dell’inflazione italiana, il Mulino, Bologna.

Snower D. (1996) "The Low-Skills, Bad-Job Trap", in Acquiring Skills. Ed. Dennis J. Snower and Alison Booth. Cambridge University Press, Cambridge.

Sylos Labini P., 1977, Sindacati, inflazione e produttività, Laterza, Bari.

Warhurst C., Findlay P. (2011), More effective skills utilisation: The shifting terrain/shifting the terrain of skills policy in Scotland, mimeo, University of Sidney. 


\section{APPENDIX}

This appendix contains the following sections:

1. Distribution of the distretti across the Italian territory

2. The Interprofessional Funds (fondi interprofessionali)

3. The Multinomial Logit Model (LML)

3.1 Methodology

3.2 Data

3.3 Results

4. TL3 bodies in Italy (Provinces, Province)

4.1 Employment and unemployment in Italian provinces, 2001 and 2009

5. Identification of the Sistemi Locali del Lavoro (SLL's)

5.1 SLL Statistics, 2005

5.1.1 The role of Hides, Food and Tourism in Campania

5.1.2 The role of Hides, Food and Tourism in Veneto 
1. Distribution of the distretti across the Italian territory

\begin{tabular}{|c|c|c|c|c|}
\hline Province & Region & $\begin{array}{c}\text { N. of } \\
\text { Distretti } \\
\text { Istat }\end{array}$ & $\begin{array}{c}\text { N. of } \\
\text { Distretti } \\
\text { S.Paolo }\end{array}$ & $\begin{array}{c}\text { Weight of of } \\
\text { distretti-based } \\
\text { exports over } \\
\text { total provincial } \\
\text { exports }\end{array}$ \\
\hline Alessandria & Piemonte & 1 & 3 & 17,7 \\
\hline Asti & Piemonte & 1 & 1 & 16,1 \\
\hline Biella & Piemonte & 2 & 2 & 60 \\
\hline Cuneo & Piemonte & 1 & 3 & 26,3 \\
\hline Torino & Piemonte & 0 & 1 & 1,5 \\
\hline Verbano-Cusio-Ossola & Piemonte & 0 & 2 & 16,9 \\
\hline Vercelli & Piemonte & 0 & 1 & 15 \\
\hline Aosta & Valle d'Aosta & 0 & 0 & 0 \\
\hline Bergamo & Lombardia & 2 & 2 & 6,7 \\
\hline Brescia & Lombardia & 2 & 5 & 44,8 \\
\hline Como & Lombardia & 1 & 2 & 29,3 \\
\hline Cremona & Lombardia & 2 & 1 & 1 \\
\hline Lecco & Lombardia & 2 & 1 & 49,9 \\
\hline Lodi & Lombardia & 0 & 0 & 0 \\
\hline Mantova & Lombardia & 1 & 3 & 23,4 \\
\hline Milano & Lombardia & 0 & 1 & 2,1 \\
\hline Novara & Lombardia & 1 & 1 & 21,4 \\
\hline Pavia & Lombardia & 1 & 2 & 6,8 \\
\hline Sondrio & Lombardia & 0 & 0 & 0 \\
\hline Varese & Lombardia & 0 & 3 & 15,7 \\
\hline Trento & Trentino-Alto Adige & 1 & 3 & 13,2 \\
\hline Bolzano-Bozen & Trentino-Alto Adige & 0 & 3 & 19,9 \\
\hline Belluno & Veneto & 2 & 1 & 53,2 \\
\hline Padova & Veneto & 2 & 2 & 6,7 \\
\hline Rovigo & Veneto & 1 & 0 & 0 \\
\hline Treviso & Veneto & 2 & 5 & 43,7 \\
\hline Venezia & Veneto & 0 & 2 & 9,9 \\
\hline Verona & Veneto & 2 & 8 & 34,6 \\
\hline Vicenza & Veneto & 2 & 7 & 38,5 \\
\hline Genova & Liguria & 0 & 0 & 0,2 \\
\hline Imperia & Liguria & 0 & 1 & 12,5 \\
\hline La Spezia & Liguria & 0 & 0 & 0 \\
\hline Savona & Liguria & 0 & 1 & 9,3 \\
\hline Gorizia & Friuli-Venezia Giulia & 0 & 1 & 1 \\
\hline Pordenone & Friuli-Venezia Giulia & 2 & 3 & 31,1 \\
\hline Trieste & Friuli-Venezia Giulia & 0 & 1 & 1 \\
\hline Udine & Friuli-Venezia Giulia & 0 & 2 & 10,6 \\
\hline Bologna & Emilia-Romagna & 0 & 2 & 19,7 \\
\hline Ferrara & Emilia-Romagna & 0 & 1 & 5,6 \\
\hline
\end{tabular}




\begin{tabular}{|c|c|c|c|c|}
\hline Forlì-Cesena & Emilia-Romagna & 1 & 3 & 21,8 \\
\hline Modena & Emilia-Romagna & 2 & 4 & 31 \\
\hline Parma & Emilia-Romagna & 0 & 3 & 12,6 \\
\hline Piacenza & Emilia-Romagna & 0 & 1 & 4,7 \\
\hline Ravenna & Emilia-Romagna & 2 & 2 & 5,1 \\
\hline Reggio nell'Emilia & Emilia-Romagna & 2 & 4 & 19 \\
\hline Rimini & Emilia-Romagna & 0 & 1 & 9,3 \\
\hline Arezzo & Toscana & 2 & 3 & 31,2 \\
\hline Firenze & Toscana & 1 & 5 & 36,1 \\
\hline Grosseto & Toscana & 0 & 0 & 0 \\
\hline Livorno & Toscana & 0 & 0 & 0 \\
\hline Lucca & Toscana & 0 & 3 & 23,8 \\
\hline Massa-Carrara & Toscana & 0 & 1 & 17 \\
\hline Pisa & Toscana & 0 & 1 & 26,5 \\
\hline Pistoia & Toscana & 0 & 3 & 22,2 \\
\hline Prato & Toscana & 2 & 1 & 58,2 \\
\hline Siena & Toscana & 1 & 2 & 32,8 \\
\hline Perugia & Umbria & 1 & 4 & 24,7 \\
\hline Terni & Umbria & 0 & 0 & 0 \\
\hline Ancona & Marche & 2 & 2 & 26,1 \\
\hline Ascoli Piceno & Marche & 2 & 2 & 37,7 \\
\hline Macerata & Marche & 2 & 3 & 34,3 \\
\hline Pesaro e Urbino & Marche & 2 & 3 & 24,8 \\
\hline Frosinone & Lazio & 0 & 0 & 0 \\
\hline Latina & Lazio & 0 & 0 & 0 \\
\hline Rieti & Lazio & 0 & 0 & 0 \\
\hline Roma & Lazio & 0 & 0 & 0 \\
\hline Viterbo & Lazio & 0 & 1 & 29,6 \\
\hline Chieti & Abruzzo & 1 & 3 & 9,4 \\
\hline L'Aquila & Abruzzo & 0 & 0 & 0 \\
\hline Pescara & Abruzzo & 0 & 3 & 28,1 \\
\hline Teramo & Abruzzo & 2 & 2 & 13,5 \\
\hline Campobasso & Molise & 1 & 0 & 0 \\
\hline Isernia & Molise & 0 & 0 & 0 \\
\hline Avellino & Campania & 1 & 1 & 13 \\
\hline Benevento & Campania & 1 & 0 & 0 \\
\hline Caserta & Campania & 0 & 2 & 6,6 \\
\hline Napoli & Campania & 0 & 4 & 15 \\
\hline Salerno & Campania & 0 & 1 & 41,5 \\
\hline Bari & Puglia & 1 & 5 & 29,8 \\
\hline Brindisi & Puglia & 0 & 0 & 0 \\
\hline Foggia & Puglia & 0 & 1 & 10,4 \\
\hline Lecce & Puglia & 1 & 2 & 22,5 \\
\hline Taranto & Puglia & 0 & 0 & 0 \\
\hline
\end{tabular}




\begin{tabular}{|l|l|l|l|l|}
\hline Matera & Basilicata & 0 & 1 & 20,7 \\
\hline Potenza & Basilicata & 0 & 0 & 0 \\
\hline Catanzaro & Calabria & 0 & 0 & 0 \\
\hline Cosenza & Calabria & 0 & 0 & 0 \\
\hline Crotone & Calabria & 0 & 0 & 0 \\
\hline Reggio di Calabria & Calabria & 0 & 0 & 0 \\
\hline Vibo Valentia & Calabria & 0 & 0 & 0 \\
\hline Agrigento & Sicilia & 0 & 1 & 21,2 \\
\hline Caltanissetta & Sicilia & 0 & 0 & 0 \\
\hline Catania & Sicilia & 0 & 1 & 9,4 \\
\hline Enna & Sicilia & 0 & 0 & 0 \\
\hline Messina & Sicilia & 0 & 0 & 0 \\
\hline Palermo & Sicilia & 0 & 1 & 5,2 \\
\hline Ragusa & Sicilia & 0 & 1 & 30,7 \\
\hline Siracusa & Sicilia & 0 & 0 & 0,1 \\
\hline Trapani & Sicilia & 0 & 1 & 18,6 \\
\hline Cagliari & Sardegna & 0 & 0 & 0 \\
\hline Nuoro & Sardegna & 0 & 0 & 0 \\
\hline Oristano & Sardegna & 0 & 0 & 0 \\
\hline Sassari & Sardegna & 0 & 2 & 32,6 \\
\hline
\end{tabular}


2. The interprofessional funds (fondi interprofessionali)

\begin{tabular}{|c|c|c|c|}
\hline Sector & Target & Funds & Promoting organisations \\
\hline \multirow{8}{*}{ Tertiary } & Managers & $\begin{array}{l}\text { Fondir Fondo per la formazione } \\
\text { continua dei dirigenti del terziario }\end{array}$ & $\begin{array}{l}\text { Confcommercio; Abi; Ania; } \\
\text { Confetra; Fendac; } \\
\text { Federdirigenti credito; Sinfub; } \\
\text { Fidia }\end{array}$ \\
\hline & Workers & $\begin{array}{l}\text { Fon.Ter Fondo per la formazione } \\
\text { continua del terziario }\end{array}$ & Confesercenti; Cgil; Cisl; Uil \\
\hline & Workers & $\begin{array}{l}\text { Fondoprofessioni Fondo per la } \\
\text { formazione continua negli studi } \\
\text { professionali e nelle aziende ad essi } \\
\text { collegate }\end{array}$ & $\begin{array}{l}\text { Consilp; Confprofessioni; } \\
\text { Confedertecnica; Cipa; Cgil; } \\
\text { Cisl; Uil }\end{array}$ \\
\hline & Workers & $\begin{array}{l}\text { For.Te. Fondo per la formazione } \\
\text { continua del terziario }\end{array}$ & $\begin{array}{l}\text { Confcommercio; } \\
\text { Cgil; Cisl; Uil }\end{array}$ \\
\hline & Workers & $\begin{array}{l}\text { Fondazienda Fondo per la formazione } \\
\text { continua dei quadri e dei dipendenti dei } \\
\text { comparti del commercio - turismo - } \\
\text { servizi, artigianato e piccola e media } \\
\text { impresa }\end{array}$ & $\begin{array}{l}\text { Confterziario; } \\
\text { Conflavoratori }\end{array}$ \\
\hline & Workers & $\begin{array}{l}\text { Fon.Ar.Com } \text { Fondo paritetico } \\
\text { interprofessionale per la formazione } \\
\text { continua nel comparto del terziario, } \\
\text { dell'artigianato e delle piccole e medie } \\
\text { imprese }\end{array}$ & $\begin{array}{l}\text { Cifa - Conf. Federazioni } \\
\text { autonome; Conf.s.a.l. - } \\
\text { Confederazione } \quad \text { sindacati } \\
\text { autonomi lavoratori }\end{array}$ \\
\hline & Workers & $\begin{array}{l}\text { Fondo Banche Assicurazioni Fondo } \\
\text { paritetico interprofessionale nazionale } \\
\text { per la formazione continua nei settori del } \\
\text { credito e delle assicurazioni }\end{array}$ & Abi; Ania; Cgil; Cisl; Uil \\
\hline & Workers & $\begin{array}{l}\text { Fondo Formazione Servizi Pubblici } \\
\text { Fondo paritetico interprofessionale } \\
\text { nazionale per la formazione Continua nei } \\
\text { Servizi Pubblici }\end{array}$ & Confservizi; Cgil; Cisl; Uil \\
\hline
\end{tabular}




\begin{tabular}{|c|c|c|c|}
\hline & Workers & $\begin{array}{l}\text { Formazienda } \text { Fondo } \\
\text { interprofessionale nazionale per la } \\
\text { formazione continua nel comparto del } \\
\text { commercio, del turismo, dei servizi, delle } \\
\text { professioni e delle piccole e medie } \\
\text { imprese }\end{array}$ & $\begin{array}{l}\text { Sistema Commercio } \\
\text { Impresa; Conf.s.a.l. }\end{array}$ \\
\hline & Workers & Fonditalia Fondo Formazione Italia & Federterziario-Claai; Ugl \\
\hline \multirow{6}{*}{ Manufacturing } & Managers & $\begin{array}{l}\text { Fondirigenti Fondo per la formazione } \\
\text { continua dei dirigenti delle aziende } \\
\text { produttrici di beni e servizi }\end{array}$ & Confindustria; Federmanager \\
\hline & Managers & $\begin{array}{l}\text { Fondo Dirigenti PMI Fondo dei } \\
\text { dirigenti delle piccole e medie imprese } \\
\text { industriali }\end{array}$ & Confapi; Federmanager \\
\hline & Workers & $\begin{array}{l}\text { Fondimpresa Fondo per la formazione } \\
\text { continua delle imprese associate a } \\
\text { Confindustria }\end{array}$ & Confindustria; Cgil; Cisl; Uil \\
\hline & Workers & $\begin{array}{l}\text { Fondo Artigianato Formazione Fondo } \\
\text { per la formazione continua nelle imprese } \\
\text { artigiane }\end{array}$ & $\begin{array}{l}\text { Confartigianato; Cna; } \\
\text { Casartigiani; Cgil; Cisl; Uil; } \\
\text { Claai }\end{array}$ \\
\hline & Workers & $\begin{array}{l}\text { Fondo Formazione PMI Fondo per la } \\
\text { formazione continua nelle PMI }\end{array}$ & Confapi; Cgil; Cisl; Uil \\
\hline & Workers & $\begin{array}{l}\text { Fon.Coop Fondo per la formazione } \\
\text { continua nelle imprese cooperative }\end{array}$ & $\begin{array}{l}\text { A.G.C.I.; Confcooperative; } \\
\text { Legacoop; Cgil; Cisl.; Uil }\end{array}$ \\
\hline Agriculture & Workers & $\begin{array}{l}\text { For.Agri Fondo per la formazione } \\
\text { continua in agricoltura }\end{array}$ & 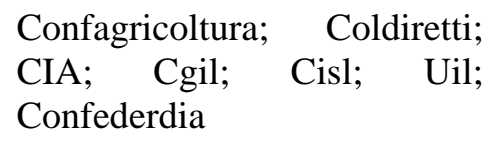 \\
\hline Other & Workers & $\begin{array}{l}\text { Fond.E.R. Fondo per la formazione } \\
\text { continua negli enti ecclesiastici, } \\
\text { associazioni, fondazioni, cooperative, } \\
\text { imprese e aziende di ispirazione religiosa }\end{array}$ & Agidae; Cgil; Cisl; Uil \\
\hline
\end{tabular}




\section{The Multinomial Logit Model (LML)}

\subsection{Methodology}

The Multinomial Logit Model (MLM) is a regression model where the dependent variable is categorical (a set of categories which cannot be ordered in any meaningful way) and consists of more than two categories. The MLM is used to predict the probabilities of the different possible outcomes of the dependent variable given a set of continuous, categorical or binary regressors. A typical application of the MLM relates to how various personal characteristics (e.g. age, years of schooling, marital status, gender, and race) affect choice of occupation (classified as 1 = blue-collar, 2 = clerical, $3=$ other). Note that there is no sense that these choices are ordered.

The MLM assumes that each regressor has a single value for each observation, and that the dependent variable cannot be perfectly predicted from the regressors for any observation. It also relies on the Independence of Irrelevant Alternatives (IIA) hypothesis, which states that the odds of a given category do not depend on other alternatives that are not relevant (e.g. the choice between taking a car or bus to work does not change if blue and orange buses are added as possibilities). Many studies in psychology show that individuals often violate this assumption when making choices. For instance, if choices include a blue bus, an orange bus, and a car, many people would simply choose between "any bus" and "a car". In such cases the MLM may impose too much constraint on the relative preferences between the alternative choices, and researchers should use other models (the nested logit, or the multinomial probit model).

When using the MLM, one category of the dependent variable is chosen as the comparison (base) category. Separate relative risk ratios (RRRs or odds ratios) are computed for each category of the dependent variable, vis-à-vis the base category, for all regressors. RRRs represent the change in the odds of being in a given category, with respect to the base category, associated with a unit change in a regressor. The statistical significance of the odds ratios is conveyed by the z-statistics. In our analysis, we take the odds of being in low-skill equilibrium as the base category (we also take Sector 1 - the primary sector - as the default case for the sector dummies, while this property applies to Zone 6 for the area dummies).

For instance, in Model 1 below, being in Zone 4 rather than in Zone 6 almost treble (multiplies by 2.73) the odds of experiencing a high-skill, rather than low-skill, equilibrium. This effect is significant at the 5\% significance level (the z-ratio being larger than 2 in absolute value). On the other hand, always in Model 1, the change in the odds of experiencing a high-skill, rather than low-skilled equilibrium associated to being in Zone 5 rather than in Zone 6 is not significant at all.

\subsection{Data}

\begin{tabular}{|l|l|l|l|l|}
\hline \multicolumn{1}{|c|}{ Province } & \multicolumn{1}{c|}{ sector } & \multicolumn{1}{c|}{ Population } & \multicolumn{1}{c|}{ firm_size } & \multicolumn{1}{c|}{ patents } \\
\hline Vercelli & 1 & 179,798 & 3,616 & 0,018243 \\
\hline Torino & 2 & 2297,598 & 3,857 & 0,007582 \\
\hline Asti & 1 & 221,151 & 4,521 & 0,042369 \\
\hline Verbano-Cusio-Ossola & 2 & 163,121 & 3,343 & 0 \\
\hline Biella & 2 & 186,698 & 4,556 & 0,640553 \\
\hline Alessandria & 1 & 439,414 & 4,265 & 0,029744 \\
\hline Cuneo & 1 & 589,586 & 4,569 & 0,430896 \\
\hline Aosta & 3 & 127,866 & 4,382 & 0,783398 \\
\hline Sondrio & 2 & 182,709 & 3,953 & 0,232775 \\
\hline Varese & 2 & 876,705 & 3,437 & 0,000376 \\
\hline
\end{tabular}




\begin{tabular}{|c|c|c|c|c|}
\hline Mantova & 1 & 412,606 & 3,821 & 0,080876 \\
\hline Bergamo & 2 & 1087,204 & 4,062 & 0,064882 \\
\hline Lodi & 2 & 225,825 & 3,368 & 0,014525 \\
\hline Pavia & 2 & 544,23 & 4,008 & 0,036437 \\
\hline Como & 2 & 590,05 & 4,167 & 0,013677 \\
\hline Milano & 3 & 3462,703 & 4,043 & 0,020005 \\
\hline Cremona & 2 & 362,061 & 4,339 & 0,009446 \\
\hline Novara & 2 & 368,864 & 3,068 & 0,00385 \\
\hline Brescia & 2 & 1242,923 & 2,944 & 0,003379 \\
\hline Lecco & 2 & 337,912 & 3,828 & 0,00148 \\
\hline Trento & 3 & 524,826 & 3,681 & 0,008631 \\
\hline Bolzano-Bozen & 1 & 503,434 & 3,230 & 0,011183 \\
\hline Treviso & 2 & 883,84 & 3,781 & 0,001131 \\
\hline Padova & 2 & 927,73 & 3,585 & 0,006489 \\
\hline Verona & 2 & 914,382 & 4,792 & 0,717184 \\
\hline Rovigo & 1 & 247,297 & 4,545 & 0,592931 \\
\hline Belluno & 2 & 213,876 & 3,995 & 0,109456 \\
\hline Vicenza & 2 & 866,398 & 4,413 & 0,045637 \\
\hline Venezia & 3 & 858,915 & 3,260 & 0,003109 \\
\hline La Spezia & 3 & 223,606 & 3,772 & 0,222445 \\
\hline Genova & 3 & 883,18 & 3,850 & 0,023076 \\
\hline Savona & 3 & 287,315 & 3,786 & 0,073021 \\
\hline Imperia & 1 & 221,885 & 3,584 & 0,123803 \\
\hline Pordenone & 2 & 313,87 & 3,873 & 0,008698 \\
\hline Udine & 2 & 541,036 & 3,635 & 0,031994 \\
\hline Trieste & 3 & 236,546 & 3,423 & 0,00985 \\
\hline Gorizia & 2 & 142,627 & 3,991 & 0,137632 \\
\hline Piacenza & 2 & 288,003 & 3,796 & 0,066388 \\
\hline Modena & 2 & 694,579 & 3,959 & 0,006191 \\
\hline Rimini & 3 & 325,219 & 3,997 & 0,013837 \\
\hline Forlì-Cesena & 1 & 392,329 & 4,037 & 0,010399 \\
\hline Parma & 2 & 437,349 & 4,003 & 0,013719 \\
\hline Bologna & 2 & 984,342 & 3,848 & 0,002286 \\
\hline Ravenna & 1 & 389,509 & 4,547 & 0,70802 \\
\hline Reggio nell'Emilia & 2 & 525,267 & 3,284 & 0,00396 \\
\hline Ferrara & 1 & 358,972 & 4,042 & 0,077053 \\
\hline Pisa & 3 & 414,154 & 3,136 & 0,00169 \\
\hline Firenze & 3 & 991,862 & 3,118 & 0,000141 \\
\hline Arezzo & 2 & 348,127 & 4,003 & 0,088387 \\
\hline Pistoia & 1 & 292,108 & 4,576 & 0,097567 \\
\hline Livorno & 3 & 341,453 & 3,675 & 0,030253 \\
\hline Lucca & 2 & 392,182 & 3,873 & 0,039828 \\
\hline Siena & 1 & 271,365 & 3,637 & 0,020747 \\
\hline Grosseto & 1 & 227,063 & 3,646 & 0,031577 \\
\hline
\end{tabular}




\begin{tabular}{|c|c|c|c|c|}
\hline Massa-Carrara & 3 & 203,642 & 3,616 & 0,016107 \\
\hline Prato & 2 & 248,174 & 3,857 & 0,070193 \\
\hline Terni & 1 & 233,719 & 4,556 & 0,511683 \\
\hline Perugia & 2 & 667,071 & 4,265 & 0,019593 \\
\hline Pesaro e Urbino & 2 & 365,788 & 3,957 & 0,013314 \\
\hline Macerata & 2 & 324,369 & 3,620 & 0,002775 \\
\hline Ancona & 2 & 478,319 & 3,617 & 0,002091 \\
\hline Ascoli Piceno & 2 & 282,142 & 3,686 & 0,009463 \\
\hline Viterbo & 3 & 318,139 & 4,203 & 0,086817 \\
\hline Roma & 3 & 4154,684 & 3,277 & 0 \\
\hline Frosinone & 2 & 497,849 & 3,953 & 0,085428 \\
\hline Rieti & 1 & 159,979 & 3,437 & 0,002063 \\
\hline Latina & 1 & 551,217 & 3,821 & 0,060539 \\
\hline Chieti & 2 & 396,852 & 4,043 & 0,174549 \\
\hline Pescara & 3 & 321,192 & 4,339 & 0,010648 \\
\hline L'Aquila & 2 & 309,264 & 3,068 & 0,004592 \\
\hline Teramo & 1 & 311,59 & 2,944 & 0,013479 \\
\hline Campobasso & 1 & 231,44 & 3,681 & 0,019573 \\
\hline Isernia & 1 & 88,789 & 3,596 & 0,056313 \\
\hline Benevento & 1 & 288,283 & 3,767 & 0,041626 \\
\hline Avellino & 3 & 439,036 & 4,226 & 0,080563 \\
\hline Salerno & 1 & 1107,652 & 3,368 & 0,00752 \\
\hline Napoli & 3 & 3079,685 & 3,781 & 0,000325 \\
\hline Caserta & 1 & 910,006 & 3,585 & 0,006615 \\
\hline Bari & 1 & 1418,812 & 3,089 & 0,000705 \\
\hline Taranto & 1 & 580,525 & 4,117 & 0,152862 \\
\hline Brindisi & 1 & 403,096 & 3,865 & 0,023245 \\
\hline Lecce & 1 & 813,556 & 4,305 & 0,068649 \\
\hline Foggia & 1 & 640,891 & 3,772 & 0,077611 \\
\hline Matera & 1 & 203,57 & 3,584 & 0,134941 \\
\hline Potenza & 1 & 385,309 & 3,879 & 0,040461 \\
\hline Cosenza & 1 & 734,652 & 3,423 & 0,003172 \\
\hline Crotone & 1 & 173,812 & 3,991 & 0,112938 \\
\hline Vibo Valentia & 1 & 166,891 & 3,458 & 0,005992 \\
\hline Reggio di Calabria & 1 & 565,756 & 4,361 & 0,138576 \\
\hline Catanzaro & 1 & 368,219 & 3,232 & 0,003856 \\
\hline Ragusa & 1 & 316,113 & 4,037 & 0,012907 \\
\hline Caltanissetta & 1 & 272,052 & 4,003 & 0,022055 \\
\hline Palermo & 3 & 1246,094 & 3,848 & 0,001806 \\
\hline Trapani & 1 & 436,283 & 4,547 & 0,632113 \\
\hline Siracusa & 1 & 403,356 & 3,284 & 0,005157 \\
\hline Agrigento & 1 & 454,593 & 4,042 & 0,060846 \\
\hline Messina & 1 & 653,81 & 4,499 & 0,154357 \\
\hline Catania & 1 & 1087,682 & 4,910 & 0,013487 \\
\hline
\end{tabular}




\begin{tabular}{|l|l|l|l|l|}
\hline Enna & 1 & 173,009 & 4,085 & 0,219815 \\
\hline Cagliari & 1 & 660,824 & 4,306 & 0,09296 \\
\hline Nuoro & 1 & 188,378 & 3,265 & 0 \\
\hline Oristano & 1 & 166,712 & 4,779 & 0,757054 \\
\hline Sassari & 1 & 406,387 & 3,136 & 0,001723 \\
\hline
\end{tabular}




\begin{tabular}{|c|c|c|c|c|c|c|}
\hline Province & $\begin{array}{c}\text { Temporary } \\
\text { contracts }\end{array}$ & Part-time & $\begin{array}{l}\text { Union } \\
\text { density }\end{array}$ & female_LF & $\begin{array}{c}\text { Population } \\
15 \_24\end{array}$ & $\begin{array}{c}\text { Foreign } \\
\text { population }\end{array}$ \\
\hline Torino & 0,1062 & 0,1403 & 0,1687 & 0,4404 & 0,0867 & 0,0863 \\
\hline Biella & 0,1062 & 0,1403 & 0,2528 & 0,4518 & 0,0829 & 0,0558 \\
\hline Asti & 0,1062 & 0,1403 & 0,2769 & 0,4239 & 0,0834 & 0,1018 \\
\hline Vercelli & 0,1062 & 0,1403 & 0,4671 & 0,4225 & 0,0851 & 0,0708 \\
\hline Alessandria & 0,1062 & 0,1403 & 0,2889 & 0,4194 & 0,0800 & 0,0901 \\
\hline Cuneo & 0,1062 & 0,1403 & 0,2180 & 0,4316 & 0,1217 & 0,0895 \\
\hline Verbano-Cusio-Ossola & 0,1062 & 0,1403 & 0,2749 & 0,4295 & 0,0832 & 0,0558 \\
\hline Aosta & 0,1349 & 0,1234 & 0,2597 & 0,4392 & 0,0875 & 0,0642 \\
\hline Brescia & 0,0886 & 0,1579 & 0,2373 & 0,3980 & 0,0949 & 0,1290 \\
\hline Pavia & 0,0886 & 0,1579 & 0,2160 & 0,4327 & 0,0833 & 0,0895 \\
\hline Varese & 0,0886 & 0,1579 & 0,1939 & 0,4189 & 0,1185 & 0,0758 \\
\hline Mantova & 0,0886 & 0,1579 & 0,2725 & 0,4076 & 0,1122 & 0,1217 \\
\hline Milano & 0,0886 & 0,1579 & 0,1489 & 0,4414 & 0,0978 & 0,1176 \\
\hline Novara & 0,0886 & 0,1579 & 0,2498 & 0,4268 & 0,0881 & 0,0865 \\
\hline Lecco & 0,0886 & 0,1579 & 0,2977 & 0,4138 & 0,0952 & 0,0764 \\
\hline Como & 0,0886 & 0,1579 & 0,3453 & 0,4234 & 0,0921 & 0,0740 \\
\hline Sondrio & 0,0886 & 0,1579 & 0,3375 & 0,4247 & 0,0981 & 0,0428 \\
\hline Cremona & 0,0886 & 0,1579 & 0,3134 & 0,4037 & 0,0904 & 0,1035 \\
\hline Bergamo & 0,0886 & 0,1579 & 0,2557 & 0,3870 & 0,0982 & 0,1022 \\
\hline Lodi & 0,0886 & 0,1579 & 0,2597 & 0,4284 & 0,0927 & 0,1043 \\
\hline Trento & 0,1524 & 0,1880 & 0,2552 & 0,4321 & 0,0995 & 0,0877 \\
\hline Bolzano-Bozen & 0,1166 & 0,1499 & 0,2165 & 0,4324 & 0,1096 & 0,0778 \\
\hline Treviso & 0,1066 & 0,1567 & 0,1798 & 0,4061 & 0,0947 & 0,1121 \\
\hline Venezia & 0,1066 & 0,1567 & 0,2299 & 0,4250 & 0,0854 & 0,0815 \\
\hline Rovigo & 0,1066 & 0,1567 & 0,3104 & 0,4063 & 0,0864 & 0,0685 \\
\hline Belluno & 0,1066 & 0,1567 & 0,2628 & 0,4341 & 0,0881 & 0,0621 \\
\hline Padova & 0,1066 & 0,1567 & 0,1938 & 0,4195 & 0,1191 & 0,0928 \\
\hline Verona & 0,1066 & 0,1567 & 0,1902 & 0,4166 & 0,0952 & 0,1107 \\
\hline Vicenza & 0,1066 & 0,1567 & 0,1774 & 0,4066 & 0,0989 & 0,1084 \\
\hline La Spezia & 0,0905 & 0,1292 & 0,2464 & 0,3899 & 0,0799 & 0,0678 \\
\hline Savona & 0,0905 & 0,1292 & 0,2330 & 0,4317 & 0,0763 & 0,0709 \\
\hline Imperia & 0,0905 & 0,1292 & 0,3031 & 0,4224 & 0,0841 & 0,0885 \\
\hline Genova & 0,0905 & 0,1292 & 0,2771 & 0,4548 & 0,0797 & 0,0670 \\
\hline Pordenone & 0,1328 & 0,1729 & 0,2107 & 0,4274 & 0,0887 & 0,1102 \\
\hline Gorizia & 0,1328 & 0,1729 & 0,2292 & 0,4262 & 0,0776 & 0,0735 \\
\hline Udine & 0,1328 & 0,1729 & 0,2046 & 0,4161 & 0,0835 & 0,0699 \\
\hline Trieste & 0,1328 & 0,1729 & 0,1890 & 0,4392 & 0,0776 & 0,0759 \\
\hline Ferrara & 0,1168 & 0,1336 & 0,3479 & 0,4532 & 0,0724 & 0,0683 \\
\hline Modena & 0,1168 & 0,1336 & 0,2953 & 0,4490 & 0,1145 & 0,1189 \\
\hline Forlì-Cesena & 0,1168 & 0,1336 & 0,2979 & 0,4341 & 0,0866 & 0,0991 \\
\hline Bologna & 0,1168 & 0,1336 & 0,2490 & 0,4633 & 0,0755 & 0,0963 \\
\hline Piacenza & 0,1168 & 0,1336 & 0,2430 & 0,4139 & 0,0855 & 0,1255 \\
\hline
\end{tabular}




\begin{tabular}{|c|c|c|c|c|c|c|}
\hline Ravenna & 0,1168 & 0,1336 & 0,3340 & 0,4523 & 0,0785 & 0,1044 \\
\hline Parma & 0,1168 & 0,1336 & 0,2908 & 0,4333 & 0,0850 & 0,1147 \\
\hline Reggio nell'Emilia & 0,1168 & 0,1336 & 0,3170 & 0,4307 & 0,0900 & 0,1228 \\
\hline Rimini & 0,1168 & 0,1336 & 0,2341 & 0,4437 & 0,0883 & 0,0938 \\
\hline Livorno & 0,1236 & 0,1759 & 0,2996 & 0,4572 & 0,0818 & 0,0635 \\
\hline Grosseto & 0,1236 & 0,1759 & 0,3448 & 0,4366 & 0,0826 & 0,0841 \\
\hline Pistoia & 0,1236 & 0,1759 & 0,2796 & 0,4405 & 0,0867 & 0,0895 \\
\hline Prato & 0,1236 & 0,1759 & 0,2532 & 0,4318 & 0,1161 & 0,1267 \\
\hline Siena & 0,1236 & 0,1759 & 0,3536 & 0,4408 & 0,1086 & 0,1031 \\
\hline Arezzo & 0,1236 & 0,1759 & 0,2588 & 0,4162 & 0,0924 & 0,1020 \\
\hline Pisa & 0,1236 & 0,1759 & 0,2285 & 0,4272 & 0,0842 & 0,0813 \\
\hline Lucca & 0,1236 & 0,1759 & 0,2361 & 0,4013 & 0,0858 & 0,0676 \\
\hline Firenze & 0,1236 & 0,1759 & 0,2499 & 0,4477 & 0,0833 & 0,1048 \\
\hline Massa-Carrara & 0,1236 & 0,1759 & 0,2440 & 0,4433 & 0,0856 & 0,0627 \\
\hline Perugia & 0,1747 & 0,1500 & 0,2839 & 0,4398 & 0,0940 & 0,1089 \\
\hline Terni & 0,1747 & 0,1500 & 0,2819 & 0,4300 & 0,0861 & 0,0882 \\
\hline Macerata & 0,1308 & 0,1448 & 0,2037 & 0,4304 & 0,0970 & 0,1049 \\
\hline Pesaro e Urbino & 0,1308 & 0,1448 & 0,2660 & 0,4247 & 0,0939 & 0,0921 \\
\hline Ascoli Piceno & 0,1308 & 0,1448 & 0,2086 & 0,4096 & 0,1714 & 0,1062 \\
\hline Ancona & 0,1308 & 0,1448 & 0,2440 & 0,4617 & 0,0907 & 0,0864 \\
\hline Viterbo & 0,1083 & 0,1483 & 0,3005 & 0,3486 & 0,0964 & 0,0825 \\
\hline Roma & 0,1083 & 0,1483 & 0,1651 & 0,4400 & 0,0953 & 0,0976 \\
\hline Latina & 0,1083 & 0,1483 & 0,2524 & 0,3856 & 0,1108 & 0,0622 \\
\hline Frosinone & 0,1083 & 0,1483 & 0,2519 & 0,3584 & 0,1401 & 0,0418 \\
\hline Rieti & 0,1083 & 0,1483 & 0,2735 & 0,4056 & 0,0987 & 0,0681 \\
\hline Chieti & 0,1425 & 0,1291 & 0,2264 & 0,3800 & 0,1026 & 0,0460 \\
\hline Pescara & 0,1425 & 0,1291 & 0,2220 & 0,4048 & 0,1291 & 0,0445 \\
\hline L'Aquila & 0,1425 & 0,1291 & 0,2765 & 0,4050 & 0,1025 & 0,0654 \\
\hline Teramo & 0,1425 & 0,1291 & 0,2586 & 0,4005 & 0,1078 & 0,0736 \\
\hline Isernia & 0,1323 & 0,1247 & 0,3221 & 0,3993 & 0,1104 & 0,0242 \\
\hline Campobasso & 0,1323 & 0,1247 & 0,3532 & 0,3907 & 0,1084 & 0,0258 \\
\hline Avellino & 0,1402 & 0,1108 & 0,3060 & 0,3516 & 0,1212 & 0,0235 \\
\hline Benevento & 0,1402 & 0,1108 & 0,2006 & 0,3766 & 0,1208 & 0,0191 \\
\hline Salerno & 0,1402 & 0,1108 & 0,2501 & 0,3776 & 0,1235 & 0,0303 \\
\hline Caserta & 0,1402 & 0,1108 & 0,2425 & 0,3227 & 0,1322 & 0,0317 \\
\hline Napoli & 0,1402 & 0,1108 & 0,2063 & 0,3155 & 0,1334 & 0,0224 \\
\hline Lecce & 0,1494 & 0,0946 & 0,2493 & 0,3748 & 0,1136 & 0,0194 \\
\hline Foggia & 0,1494 & 0,0946 & 0,3187 & 0,2980 & 0,1245 & 0,0287 \\
\hline Taranto & 0,1494 & 0,0946 & 0,3445 & 0,3215 & 0,1177 & 0,0140 \\
\hline Brindisi & 0,1494 & 0,0946 & 0,3695 & 0,3568 & 0,1206 & 0,0166 \\
\hline Bari & 0,1494 & 0,0946 & 0,2137 & 0,3440 & 0,1379 & 0,0249 \\
\hline Potenza & 0,1502 & 0,0994 & 0,3811 & 0,3793 & 0,1455 & 0,0176 \\
\hline Matera & 0,1502 & 0,0994 & 0,3756 & 0,3727 & 0,1174 & 0,0305 \\
\hline Cosenza & 0,2176 & 0,0932 & 0,3230 & 0,3681 & 0,1199 & 0,0285 \\
\hline
\end{tabular}




\begin{tabular}{|l|l|l|l|l|l|l|}
\hline Reggio di Calabria & 0,2176 & 0,0932 & 0,3405 & 0,3620 & 0,1277 & 0,0391 \\
\hline Crotone & 0,2176 & 0,0932 & 0,5359 & 0,2957 & 0,1343 & 0,0326 \\
\hline Vibo Valentia & 0,2176 & 0,0932 & 0,5688 & 0,3639 & 0,1284 & 0,0317 \\
\hline Catanzaro & 0,2176 & 0,0932 & 0,2887 & 0,3711 & 0,1236 & 0,0321 \\
\hline Ragusa & 0,1789 & 0,1394 & 0,3391 & 0,3621 & 0,1228 & 0,0584 \\
\hline Caltanissetta & 0,1789 & 0,1394 & 0,3579 & 0,3259 & 0,1306 & 0,0193 \\
\hline Messina & 0,1789 & 0,1394 & 0,3040 & 0,3738 & 0,1175 & 0,0322 \\
\hline Palermo & 0,1789 & 0,1394 & 0,2639 & 0,3591 & 0,1280 & 0,0205 \\
\hline Enna & 0,1789 & 0,1394 & 0,3635 & 0,3520 & 0,1249 & 0,0148 \\
\hline Catania & 0,1789 & 0,1394 & 0,2682 & 0,3505 & 0,1288 & 0,0215 \\
\hline Trapani & 0,1789 & 0,1394 & 0,4156 & 0,3307 & 0,1188 & 0,0257 \\
\hline Agrigento & 0,1789 & 0,1394 & 0,2827 & 0,3089 & 0,1574 & 0,0212 \\
\hline Siracusa & 0,1789 & 0,1394 & 0,3209 & 0,3520 & 0,1205 & 0,0253 \\
\hline Oristano & 0,1965 & 0,1615 & 0,2315 & 0,3999 & 0,1032 & 0,0118 \\
\hline Nuoro & 0,1965 & 0,1615 & 0,4046 & 0,4105 & 0,1270 & 0,0191 \\
\hline Sassari & 0,1965 & 0,1615 & 0,2788 & 0,4199 & 0,1238 & 0,0365 \\
\hline Cagliari & 0,1965 & 0,1615 & 0,2019 & 0,3919 & 0,1518 & 0,0196 \\
\hline
\end{tabular}




\subsection{Results of the MLM}

Model 1 - purely territorial specification (n. obs. $=206 ; L L R=-206.42 ;$ pseudo- $R 2=0.25$ )

\begin{tabular}{|l|l|l|}
\hline High-skill eq. & RRR & $\underline{Z}$ \\
\hline \hline 2009 & 0.56 & 1.25 \\
\hline \hline North-West & 4.34 & 3.93 \\
\hline \hline North-East & 4.58 & 3.77 \\
\hline \hline Centre & 4.37 & 3.96 \\
\hline \hline Zone 4 & 2.73 & 2.17 \\
\hline \hline Zone 5 & -14.35 & -0.01 \\
\hline \hline cons & -3.54 & -3.35 \\
\hline
\end{tabular}

\begin{tabular}{|l|l|l|}
\hline Skill surplus & RRR & $Z$ \\
\hline \hline 2009 & & \\
\hline North-West & -0.17 & -0.41 \\
\hline North-East & -1.36 & -1.22 \\
\hline Centre & 0.31 & 0.32 \\
\hline Zone 4 & 1.12 & 1.95 \\
\hline Zone 5 & 1.06 & 1.56 \\
\hline cons & -0.47 & -0.81 \\
\hline
\end{tabular}

\begin{tabular}{|l|l|l|}
\hline Low-skill eq. & (base) & \\
\hline \hline & & \\
\hline Skill shortage & RRR & $Z$ \\
\hline 2009 & 0.56 & 1.08 \\
\hline North-West & 18.68 & 0.01 \\
\hline North-East & 19.26 & 0.01 \\
\hline Centre & 17.57 & 0.01 \\
\hline Zone 4 & 17.50 & 0.01 \\
\hline Zone 5 & -0.41 & -0.01 \\
\hline cons & -18.31 & -0.01 \\
\hline
\end{tabular}


Model 2 - Preferred specification (n. obs. $=206 ; L L R=-131,23 ;$ pseudo- $R 2=0,52$ )

\begin{tabular}{|l|l|l|}
\hline High-skill eq. & RRR & $\underline{\text { z }}$ \\
\hline 2009 & -1.68 & -0.99 \\
\hline Sector 2 & 1.37 & 1.46 \\
\hline Sector 3 & 3.86 & 3.37 \\
\hline North-West & -2.4 & -0.72 \\
\hline North-East & -1.17 & -0.36 \\
\hline Centre & -2.96 & -0.9 \\
\hline Zone 4 & -4.01 & -1.28 \\
\hline Zone 5 & -11.73 & -0.01 \\
\hline Metropolitan & -6.64 & -1.83 \\
\hline Ln population & 3.25 & 3.63 \\
\hline Ln size & -0.25 & -0.09 \\
\hline Ln union density & 0.8 & 0.36 \\
\hline Ln share female I.f. & 11.46 & 1.38 \\
\hline Ln share population 15-24 & -4.93 & -1.6 \\
\hline Ln share foreign population & 1.67 & 1.19 \\
\hline Ln share temporary workers & -8.09 & -2.29 \\
\hline Ln share part-timers & 0.91 & 0.31 \\
\hline University_2 & 3.23 & 2.76 \\
\hline Distretti_ISTAT & -0.33 & -0.63 \\
\hline _cons & -50.04 & -2.62 \\
\hline & & \\
\hline Skill surplus & $\underline{R}$ RR & $\underline{z}$ \\
\hline 2009 & -1.40 & -1.14 \\
\hline Sector 2 & 1.17 & 1.21 \\
\hline Sector 3 & 1.19 & 1.32 \\
\hline North-West & -3.31 & -1.45 \\
\hline North-East & -2.71 & -1.19 \\
\hline Centre & -2.91 & -1.44 \\
\hline Zone 4 & -1.69 & -1.02 \\
\hline Zone 5 & -0.57 & -0.77 \\
\hline Metropolitan & -18.65 & -0.01 \\
\hline Ln population & 0.48 & 0.85 \\
\hline Ln size & -3.79 & -1.84 \\
\hline Ln union density & -2.89 & -1.74 \\
\hline Ln share female I.f. & 7.78 & 1.83 \\
\hline Ln share population 15-24 & -2.72 & -1.05 \\
\hline Ln share foreign population & 0.34 & 0.38 \\
\hline Ln share temporary workers & 3.32 & 1.59 \\
\hline Ln share part-timers & -0.01 \\
\hline University_2 & 3.12 \\
\hline Distretti_ISTAT & -0.25 \\
\hline
\end{tabular}




\begin{tabular}{|l|l|l|}
\hline _cons & 5.24 & 0.44 \\
\hline & & \\
\hline Skill gap & $\underline{R R R}$ & $\underline{Z}$ \\
\hline 2009 & -0.12 & -0.07 \\
\hline Sector 2 & 2.04 & 2.26 \\
\hline Sector 3 & 1.73 & 1.35 \\
\hline North-West & 15.72 & 0.01 \\
\hline North-East & 17.38 & 0.02 \\
\hline Centre & 15.62 & 0.01 \\
\hline Zone 4 & 15.63 & 0.01 \\
\hline Zone 5 & 0.33 & 0.00 \\
\hline Metropolitan & -20.46 & -0.01 \\
\hline Ln population & 2.77 & 3.03 \\
\hline Ln size & -1.61 & -0.57 \\
\hline Ln union density & 0.64 & 0.29 \\
\hline Ln share female I.f. & 5.70 & 0.69 \\
\hline Ln share population 15-24 & 0.62 & 0.25 \\
\hline Ln share foreign population & 0.94 & 0.65 \\
\hline Ln share temporary workers & -5.54 & -1.43 \\
\hline Ln share part-timers & -1.33 & -0.39 \\
\hline University_2 & -0.49 & -0.37 \\
\hline Distretti_ISTAT & -0.96 & -1.76 \\
\hline cons & -53.23 & -0.05 \\
\hline & & \\
\hline & & \\
\hline
\end{tabular}

The role of Campania and Veneto (n. obs. = 206; $\operatorname{LLR}=-128,15$; pseudo-R2 $=0,53$ )

\begin{tabular}{|l|l|l|}
\hline High-skill eq. & RRR & $\underline{Z}$ \\
\hline \hline Campania & -27.23 & -0.01 \\
\hline Veneto & -2.73 & -1.3 \\
\hline Skill surplus & & \\
\hline \hline Campania & RRR & $\underline{Z}$ \\
\hline Veneto & 0.74 & 0.57 \\
\hline Skill gap & -16.63 & -0.01 \\
\hline \hline Campania & \multicolumn{2}{l|}{} \\
\hline Veneto & RRR & $\underline{Z}$ \\
\hline
\end{tabular}

The role of Food and Tourism (n. obs. = 206; LLR = -127,11; pseudo-R2 = 0,54)

\begin{tabular}{|l|l|l|}
\hline High-skill eq. & RRR & $\underline{z}$ \\
\hline \hline Food & 0.14 & 0.15 \\
\hline Tourism & 1.33 & 1.16 \\
\hline & & \\
\hline Skill surplus & RRR & $\underline{z}$ \\
\hline Food & 0.9 & 1.22 \\
\hline Tourism & -0.39 & -0.26 \\
\hline & & \\
\hline Skill gap & RRR & $\underline{z}$ \\
\hline \hline
\end{tabular}




\begin{tabular}{|l|l|l|}
\hline Food & -0.81 & -0.81 \\
\hline Tourism & 2.2 & 1.99 \\
\hline
\end{tabular}


4. TL3 bodies in Italy (Provinces, Province)

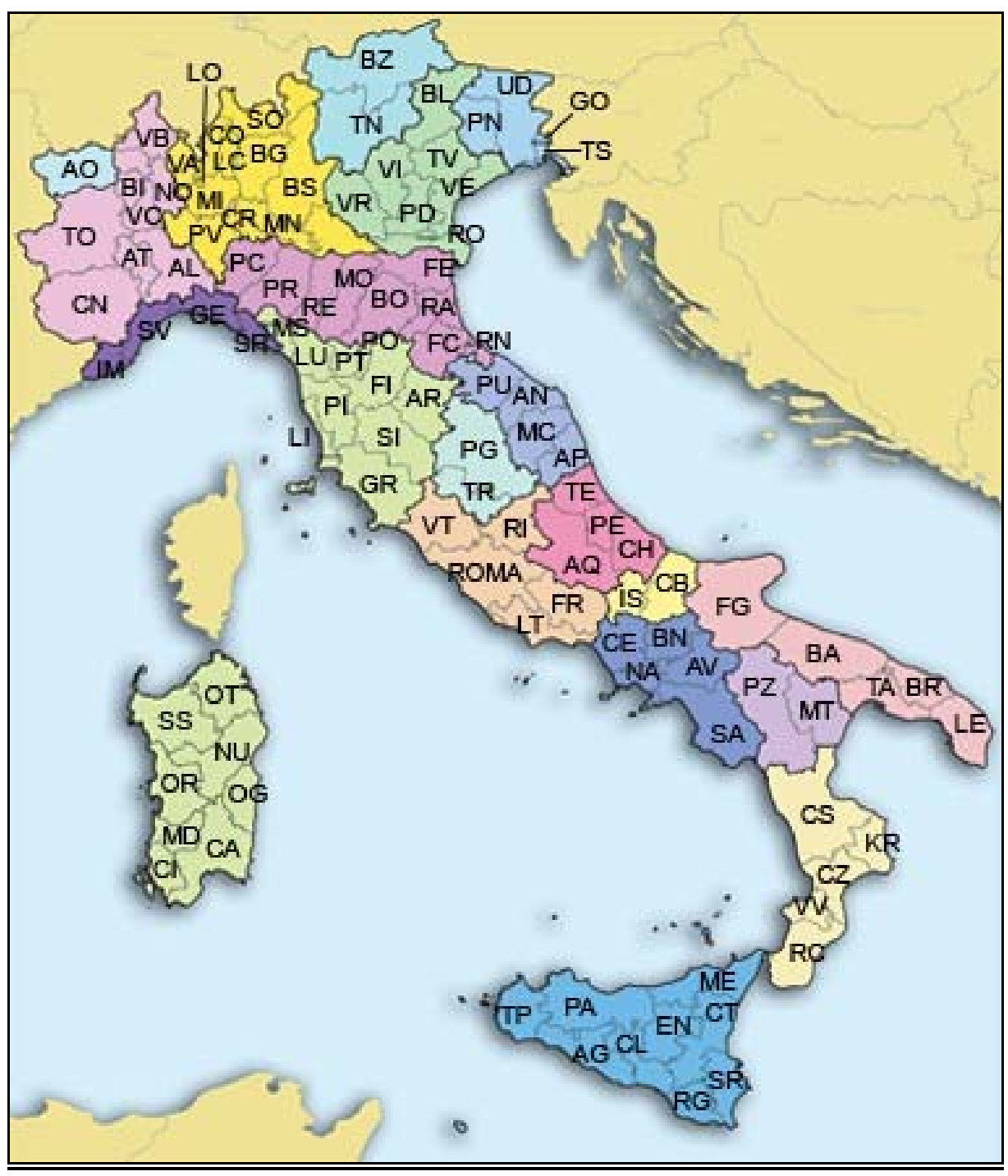


4.1 Employment and unemployment in Italian provinces, 2001 and 2009

\begin{tabular}{|c|c|c|c|c|c|c|c|c|}
\hline & \multicolumn{4}{|c|}{2001} & \multicolumn{4}{|c|}{2009} \\
\hline Provinces & $\begin{array}{l}\text { Youth } \\
\text { employm } \\
\text { ent rate }\end{array}$ & $\begin{array}{l}\text { Total } \\
\text { employ } \\
\text { ment } \\
\text { rate }\end{array}$ & $\begin{array}{l}\text { Youth } \\
\text { unemploy } \\
\text { ment rate }\end{array}$ & $\begin{array}{l}\text { Total } \\
\text { unemplo } \\
\text { yment } \\
\text { rate }\end{array}$ & $\begin{array}{l}\text { Youth } \\
\text { employment } \\
\text { rate }\end{array}$ & $\begin{array}{l}\text { Total } \\
\text { employ } \\
\text { ment } \\
\text { rate } \\
\end{array}$ & $\begin{array}{l}\text { Youth } \\
\text { unemplo } \\
\text { yment } \\
\text { rate }\end{array}$ & $\begin{array}{l}\text { Total } \\
\text { unemplo } \\
\text { yment } \\
\text { rate }\end{array}$ \\
\hline Alessandria & 33 & 43,5 & 11,7 & 4,1 & 26,9 & 45,8 & 21,2 & 5,8 \\
\hline Asti & 41 & 47,7 & 7,9 & 3,2 & 26,7 & 49,5 & 20,9 & 5,8 \\
\hline Biella & 37,1 & 48 & 9 & 2,7 & 26,7 & 48,8 & 27,2 & 6,7 \\
\hline Cuneo & 40,8 & 51,6 & 9,8 & 3,2 & 38,8 & 53,3 & 10,1 & 2,9 \\
\hline Torino & 30,8 & 47,9 & 21 & 6,2 & 22,3 & 47,6 & 31,1 & 8,3 \\
\hline Verbano & 34,9 & 47,2 & 12,8 & 4 & 31,1 & 47,4 & 12,5 & 5,1 \\
\hline Vercelli & 42 & 49,5 & 7,7 & 2,7 & 26,6 & 49,1 & 18,4 & 5,2 \\
\hline Aosta & 39,1 & 52,6 & 13,2 & 4,2 & 27,8 & 51,9 & 17,5 & 4,4 \\
\hline Bergamo & 47,6 & 51,4 & 3,5 & 1,8 & 35,2 & 51,9 & 11,6 & 3,7 \\
\hline Brescia & 43 & 51,3 & 9,7 & 3,3 & 34,7 & 51,7 & 14,2 & 5,3 \\
\hline Como & 44,9 & 52,1 & 6,6 & 2,9 & 28,2 & 50,5 & 17,6 & 5,7 \\
\hline Cremona & 34,5 & 47,8 & 11,8 & 2,4 & 26,5 & 50,1 & 21,6 & 5,5 \\
\hline Lecco & 43,7 & 50,7 & 3,3 & 1,6 & 28,9 & 52,3 & 17,2 & 4,5 \\
\hline Lodi & 42,3 & 50,8 & 15,4 & 4,7 & 30,1 & 53,3 & 16,1 & 5,4 \\
\hline Mantova & 43,5 & 50,6 & 4,2 & 1,7 & 33 & 52,5 & 15,3 & 4,8 \\
\hline Milano & 36 & 50,1 & 11,9 & 4,6 & 24,5 & 52,3 & 23,2 & 5,7 \\
\hline Novara & 45 & 47,8 & 10,4 & 3,7 & 22,7 & 49,2 & 25 & 7,6 \\
\hline Pavia & 37,1 & 49,3 & 14,8 & 3,4 & 27,9 & 50,2 & 18,6 & 5,5 \\
\hline Sondrio & 40,6 & 50,9 & 8,7 & 3 & 33 & 51,9 & 16,6 & 4,4 \\
\hline Varese & 28,3 & 49,9 & 17,5 & 5,2 & 28,8 & 49,1 & 20,1 & 6,3 \\
\hline Trento & 38,2 & 50,6 & 10,1 & 3,3 & 30,2 & 52,6 & 11,5 & 3,5 \\
\hline Bolzano & 51,7 & 57,6 & 4,6 & 1,9 & 38,1 & 57,8 & 8,9 & 2,9 \\
\hline Belluno & 43,8 & 53,6 & 7,4 & 3,7 & 28,3 & 47,9 & 18,3 & 4,4 \\
\hline Padova & 40,7 & 48,5 & 5,8 & 3,1 & 32,4 & 51,8 & 8,1 & 4,3 \\
\hline Rovigo & 36,2 & 48,1 & 21,3 & 6,4 & 29 & 47,6 & 12,5 & 3,2 \\
\hline Treviso & 41,7 & 52,4 & 7,5 & 2,5 & 32,4 & 50,8 & 9,5 & 4,7 \\
\hline Venezia & 35,9 & 49,5 & 14,9 & 5,3 & 27,1 & 47,7 & 20,7 & 5,6 \\
\hline Verona & 42,1 & 49,9 & 8,9 & 3,3 & 31,4 & 53,1 & 17 & 4,7 \\
\hline Vicenza & 44,5 & 53,6 & 4,5 & 2,2 & 27,6 & 52 & 17,5 & 5 \\
\hline Genova & 26,1 & 41,9 & 23,4 & 7,2 & 26,1 & 46,7 & 19,6 & 5,5 \\
\hline Imperia & 36,4 & 46,2 & 13,3 & 3,8 & 24,3 & 44,4 & 11,4 & 6,8 \\
\hline La Spezia & 20,3 & 41 & 35,3 & 6,1 & 18,5 & 40,9 & 20,2 & 6,6 \\
\hline Savona & 29,1 & 43,7 & 26,8 & 6,3 & 14,6 & 46,3 & 21,7 & 4,9 \\
\hline Gorizia & 39,8 & 45,3 & 12,6 & 4,7 & 21,2 & 46,2 & 25,8 & 5,7 \\
\hline Pordenone & 41,4 & 49,7 & 6 & 2,7 & 25,9 & 50,9 & 19 & 4,9 \\
\hline Trieste & 30,4 & 48,9 & 18,2 & 5,3 & 28,8 & 44,8 & 10,6 & 4,7 \\
\hline Udine & 33,6 & 46,3 & 11,5 & 4 & 24,8 & 47,4 & 20,4 & 5,6 \\
\hline Bologna & 37,2 & 49,9 & 11,3 & 3,3 & 21,4 & 52,2 & 12,3 & 3,4 \\
\hline
\end{tabular}




\begin{tabular}{|c|c|c|c|c|c|c|c|c|}
\hline Ferrara & 44,3 & 47,4 & 21,7 & 7,1 & 31,2 & 49,9 & 21,8 & 6,5 \\
\hline Forlì & 40,3 & 48,5 & 4,3 & 3,6 & 27,2 & 50,6 & 18,6 & 5,9 \\
\hline Modena & 43,9 & 55,4 & 7,3 & 2,7 & 31,3 & 53 & 21,3 & 5,2 \\
\hline Parma & 38,7 & 49,5 & 8,4 & 3,1 & 27 & 52,7 & 12,7 & 3,8 \\
\hline Piacenza & 33,6 & 46,7 & 17,1 & 5,3 & 27,6 & 51,1 & 14,5 & 2,1 \\
\hline Ravenna & 44 & 51,2 & 14,4 & 5,1 & 28,4 & 51 & 18,4 & 5,3 \\
\hline Reggio Em. & 45,6 & 55,9 & 5 & 2,2 & 30,4 & 54,9 & 20,5 & 5 \\
\hline Rimini & 37 & 50,6 & 9,5 & 5,3 & 33,6 & 51,8 & 21,5 & 7,6 \\
\hline Arezzo & 37,6 & 48,3 & 9,4 & 4,7 & 25,2 & 49 & 17,7 & 5,5 \\
\hline Firenze & 33,7 & 45,3 & 12,3 & 4,2 & 23,6 & 50,4 & 14,2 & 5 \\
\hline Grosseto & 29,1 & 46 & 26,6 & 7,2 & 32,7 & 49,2 & 14,3 & 5 \\
\hline Livorno & 23 & 45,3 & 34,1 & 8,5 & 16,2 & 45,1 & 27,2 & 5,2 \\
\hline Lucca & 31,2 & 45,8 & 13,8 & 4,5 & 34,5 & 47,1 & 10,8 & 6 \\
\hline Massa & 25,4 & 42,2 & 27,8 & 6,8 & 25,8 & 45,4 & 31,6 & 11,3 \\
\hline Pisa & 23,6 & 46,8 & 20,1 & 4 & 22,6 & 48,9 & 22,4 & 5,5 \\
\hline Pistoia & 34,1 & 47,6 & 19,1 & 5,4 & 26,4 & 47,5 & 13,9 & 5,4 \\
\hline Prato & 44,2 & 53,7 & 13,2 & 5,9 & 29,7 & 51,9 & 19,5 & 7,2 \\
\hline Siena & 33,8 & 51,4 & 9,5 & 3 & 24,8 & 48,3 & 19,8 & 5,1 \\
\hline Perugia & 27,7 & 46,4 & 16 & 5,1 & 27,8 & 48,3 & 17,5 & 6,5 \\
\hline Terni & 29 & 41,4 & 18,2 & 6,1 & 22,5 & 44,2 & 26,2 & 7,1 \\
\hline Ancona & 31,8 & 47,4 & 15,3 & 4,4 & 23,3 & 49,3 & 22,5 & 5,8 \\
\hline Ascoli Piceno & 33,9 & 46 & 13,9 & 6,2 & 23,7 & 45,8 & 25,9 & 9,6 \\
\hline Macerata & 32,8 & 48,9 & 11,4 & 4,1 & 23,6 & 47,3 & 21,4 & 5,2 \\
\hline Pesaro-Urbino & 37 & 47,9 & 7,4 & 3,5 & 34,8 & 50,5 & 21,1 & 5,9 \\
\hline Frosinone & 15,5 & 40,2 & 37,7 & 11,6 & 20,9 & 39,9 & 27,3 & 7,4 \\
\hline Latina & 21,9 & 44 & 26,8 & 9,2 & 20,2 & 43 & 30 & 10,9 \\
\hline Rieti & 18,9 & 40,6 & 38,6 & 12,5 & 16,8 & 42,9 & 31,4 & 8 \\
\hline Roma & 17,5 & 44,2 & 37,4 & 10 & 20,5 & 48,6 & 30,7 & 8,1 \\
\hline Viterbo & 24,3 & 36,3 & 30,7 & 12,2 & 16,8 & 41,7 & 35,8 & 11,7 \\
\hline Chieti & 21,7 & 43,4 & 19,3 & 5,7 & 15,3 & 40,7 & 29,8 & 8,5 \\
\hline L'Aquila & 15,3 & 41,5 & 40,3 & 8,1 & 14,8 & 41,3 & 35,2 & 9,9 \\
\hline Pescara & 29 & 43,9 & 12,9 & 5 & 16,9 & 44,3 & 16,7 & 7,9 \\
\hline Teramo & 23,4 & 43,2 & 15,9 & 4,1 & 27 & 45,2 & 16,5 & 6 \\
\hline Campobasso & 19,2 & 39,1 & 40,4 & 14,6 & 15,7 & 39 & 31,8 & 9,5 \\
\hline Isernia & 17,8 & 41 & 33,3 & 11,3 & 22,5 & 41,5 & 17,3 & 7,9 \\
\hline Avellino & 14,4 & 40,8 & 45,6 & 14,2 & 16,2 & 38,6 & 25,3 & 8,1 \\
\hline Benevento & 14,2 & 40,7 & 58,8 & 16,9 & 13,4 & 36 & 31,3 & 11,1 \\
\hline Caserta & 13,1 & 33,9 & 57,2 & 24,6 & 10,5 & 31 & 33,6 & 9 \\
\hline Napoli & 10,7 & 31,8 & 67,1 & 26,4 & 12,6 & 31,7 & 39,7 & 14,6 \\
\hline Salerno & 14,1 & 36,9 & 40,9 & 15,1 & 14,4 & 37 & 42,2 & 14 \\
\hline Bari & 21,9 & 37,8 & 34,1 & 12,1 & 20,6 & 38,3 & 28,5 & 11,1 \\
\hline Brindisi & 20,2 & 37,6 & 34,6 & 13,2 & 20,2 & 33,7 & 31,9 & 14,3 \\
\hline Foggia & 16,4 & 35,8 & 44,1 & 15,4 & 13 & 33,2 & 41,5 & 13,6 \\
\hline Lecce & 18 & 35,8 & 42,7 & 17,4 & 16,7 & 34,9 & 36,8 & 16,2 \\
\hline
\end{tabular}




\begin{tabular}{|c|c|c|c|c|c|c|c|c|}
\hline Taranto & 14,1 & 35,2 & 50,2 & 18,1 & 20,1 & 35 & 29,9 & 9,6 \\
\hline Matera & 19,3 & 38,6 & 40,6 & 15,4 & 13,1 & 37,4 & 43,4 & 12,6 \\
\hline Potenza & 14,6 & 34,9 & 48,6 & 17 & 13,9 & 37,6 & 35,2 & 10,5 \\
\hline Catanzaro & 13 & 34,3 & 56,5 & 25,3 & 14,3 & 37,6 & 32,3 & 11,3 \\
\hline Cosenza & 12,1 & 33,6 & 60,2 & 23,8 & 14,7 & 34,9 & 28,5 & 10,9 \\
\hline Crotone & 11,9 & 30,9 & 45,1 & 17,1 & 14,8 & 28,7 & 30,7 & 12 \\
\hline Reggio Cal. & 12,1 & 32,2 & 64,3 & 30,3 & 11,3 & 33 & 33 & 11,3 \\
\hline Vibo Valentia & 13,8 & 34,5 & 56,3 & 25,9 & 11,7 & 33,5 & 41,9 & 12,9 \\
\hline Agrigento & 9,4 & 30 & 66,8 & 23,6 & 14 & 33,1 & 42,5 & 17,6 \\
\hline Caltanissetta & 12,5 & 32,2 & 51,2 & 22,6 & 12,1 & 30,3 & 34,3 & 15,3 \\
\hline Catania & 15,2 & 33,4 & 52,6 & 23,1 & 15,6 & 34,2 & 33,5 & 11,3 \\
\hline Enna & 11,3 & 30,6 & 61,4 & 23,2 & 16,3 & 34,8 & 37,7 & 15,2 \\
\hline Messina & 13 & 36,5 & 60,5 & 23 & 14,5 & 35,1 & 36 & 14,1 \\
\hline Palermo & 12 & 31,8 & 63 & 25,1 & 12 & 34,3 & 54,3 & 17,9 \\
\hline Ragusa & 25,1 & 38,9 & 29 & 13,3 & 17,7 & 39,8 & 13,6 & 8,9 \\
\hline Siracusa & 13 & 36,9 & 52,2 & 14,7 & 13 & 36,1 & 21,3 & 8,5 \\
\hline Trapani & 18,5 & 34,7 & 35,2 & 13,3 & 15,7 & 33,7 & 26,4 & 11 \\
\hline Cagliari & 16,6 & 36,2 & 55,2 & 22,9 & 12,2 & 40,5 & 46,8 & 11,3 \\
\hline Nuoro & 21 & 38,7 & 40,2 & 15,3 & 17,4 & 39 & 32,8 & 10,7 \\
\hline Oristano & 20,8 & 36,8 & 40,9 & 17,5 & 18,2 & 39,7 & 43,3 & 13,9 \\
\hline Sassari & 21,2 & 42,1 & 37,1 & 14,3 & 20,3 & 40,5 & 44,3 & 17 \\
\hline ITALY & 25,9 & 43,8 & 28,2 & 9,5 & 21,7 & 44,9 & 25,4 & 7,8 \\
\hline
\end{tabular}

Source: own elaborations on ISTAT data 


\section{Identifcation of local employment systems (SLL's)}

The local employment systems (Sistemi Locali del Lavoro, SLL) are the places of everyday life for the population that lives and works there. They broadly meet the definition of self-contained labour markets. In this sense, they define the minimum territorial units in which the the income circuit is based.

The identification of SLL's is based on a multi-step process focused on employment and commuting data.

There are basically four steps:

1. Finding places that concentrate jobs and ordering them hierarchically;

2. Consolidation of locations identified by applying the $50 \%$ threshold of self-containment of labour demand and supply. To locations that satisfy this double constraint are aggregated locations that occupy the next highest level in the hierarchical order;

3. Locations identified in the previous stage undergo a second process of hierarchical ordering according to which the $75 \%$ threshold of self-containment for both the demand for labor supply must be satisfied along with the minimum threshold of 1,000 jobs. It is at this stage that SLL's are actually identified;

4. Calibration of the boundaries of the SLLs. 
Figure 5.1. Labour-market Performance of the SLLs (sistemi locali del lavoro), 2005

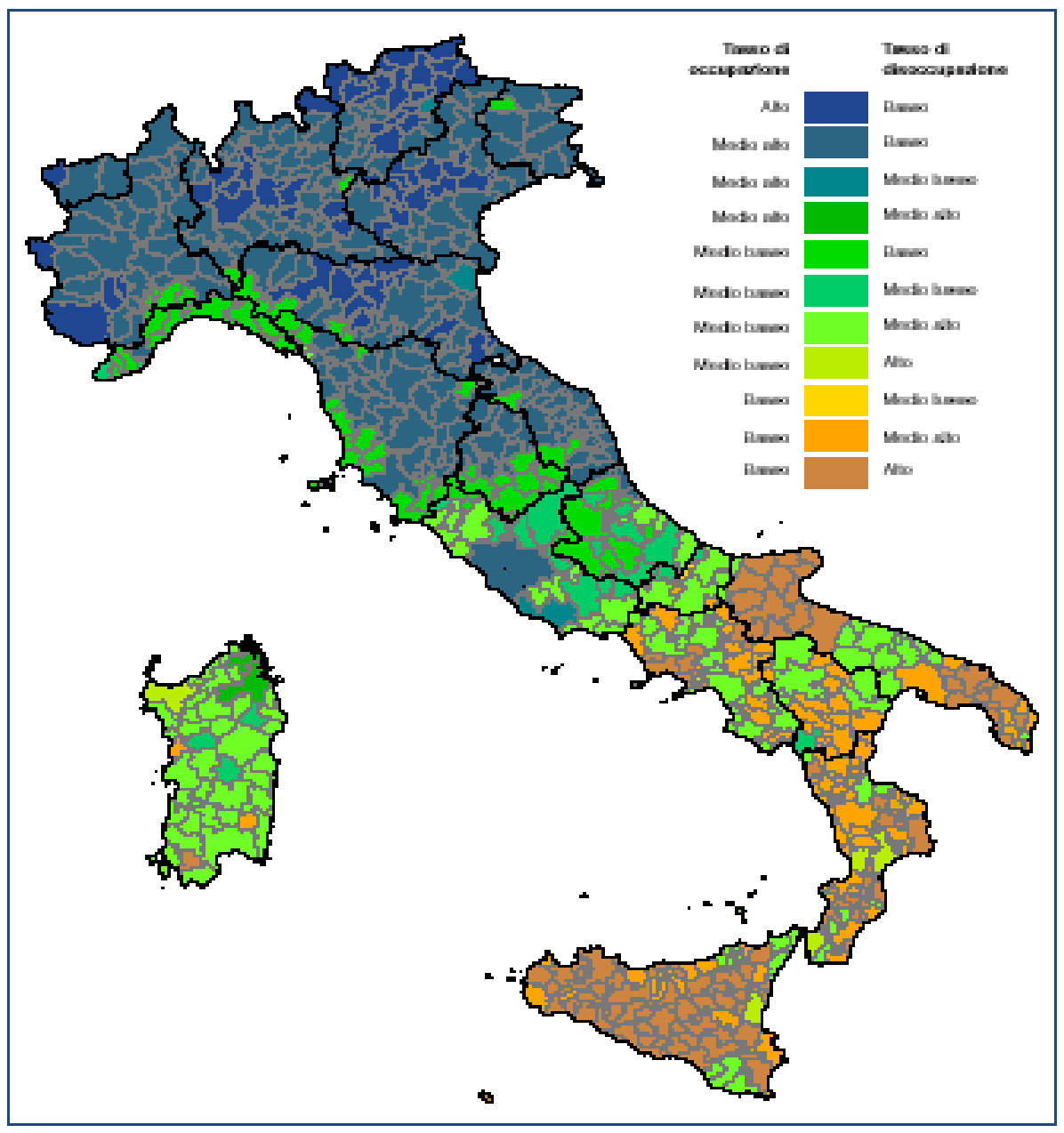




\subsection{SLL Statistics, 2005}

\subsubsection{The role of Hides, Food and Tourism in Campania}

\section{LEGEND}

Yellow $=$ Tourism, hotels and restaurants

Orange $=$ Hides and skins

Light blue $=$ Food, beverages and tobacco

\begin{tabular}{|c|c|c|c|c|c|}
\hline SLL & Distretti & VA/N 2005 & SLL & Distretti & Empl. Rate 2005 \\
\hline Avellino & 0 & 55,7 & Capri & 0 & 42,8 \\
\hline Sessa Aurunca & 0 & 50,79 & Salerno & 0 & 41,7 \\
\hline Caserta & 0 & 48,94 & Forio & 0 & 41,5 \\
\hline Salerno & 0 & 48,84 & Solofra & 1 & 41,4 \\
\hline Benevento & 0 & 47,94 & Ischia & 0 & 40,8 \\
\hline Capri & 0 & 47,87 & Amalfi & 0 & 40,7 \\
\hline Cava de' Tirreni & 0 & 47,13 & Capaccio & 0 & 39,8 \\
\hline Agropoli & 0 & 45,72 & Avellino & 0 & 39,4 \\
\hline Napoli & 0 & 45,7 & Teggiano & 0 & 39,4 \\
\hline Torre Del Greco & 0 & 44,4 & Sala Consilina & 0 & 39,3 \\
\hline Nocera Inferiore & 0 & 43,88 & San Marco Dei Cavoti & 1 & 38,8 \\
\hline Sant'angelo Dei Lombardi & 0 & 43,59 & Telese Terme & 0 & 38,6 \\
\hline Camerota & 0 & 43 & Benevento & 0 & 38,5 \\
\hline Sarno & 0 & 42,78 & Sorrento & 0 & 38,3 \\
\hline Aversa & 0 & 41,3 & Maiori & 0 & 38,3 \\
\hline Telese Terme & 0 & 40,96 & Sant'Agata de' Goti & 1 & 38 \\
\hline Ischia & 0 & 40,81 & Camerota & 0 & 37,7 \\
\hline Nola & 0 & 40,71 & Castellabate & 0 & 37,7 \\
\hline Montecalvo Irpino & 0 & 39,56 & Buccino & 1 & 37,6 \\
\hline Teggiano & 0 & 38,5 & Circello & 0 & 37,6 \\
\hline Capaccio & 0 & 38,39 & Morcone & 0 & 37,5 \\
\hline Sant'Agata de' Goti & 1 & 38,22 & Vallo Della Lucania & 0 & 37,5 \\
\hline Sorrento & 0 & 38,18 & Teano & 0 & 37,5 \\
\hline Solofra & 1 & 38,14 & Caserta & 0 & 37,4 \\
\hline Montesarchio & 0 & 37,27 & Nocera Inferiore & 0 & 37,3 \\
\hline
\end{tabular}




\begin{tabular}{|c|c|c|c|c|c|}
\hline Calitri & 0 & 37,23 & Agropoli & 0 & 37,2 \\
\hline Vallo Della Lucania & 0 & 36,69 & Lauro & 0 & 36,8 \\
\hline Amalfi & 0 & 36,56 & Sapri & 0 & 36,8 \\
\hline Torre Orsaia & 0 & 36,43 & Nola & 0 & 36,8 \\
\hline Grottaminarda & 0 & 36,24 & Piedimonte Matese & 0 & 36,6 \\
\hline Castellammare Di Stabia & 0 & 35,75 & Guardia Sanframondi & 0 & 36,5 \\
\hline Maiori & 0 & 35,32 & Montesarchio & 0 & 36,4 \\
\hline Ariano Irpino & 0 & 34,35 & Apice & 1 & 36,3 \\
\hline Sala Consilina & 0 & 34,16 & Torre Orsaia & 0 & 36,2 \\
\hline Oliveto Citra & 0 & 33,72 & Sarno & 0 & 36,2 \\
\hline Castellabate & 0 & 33,51 & Grottaminarda & 0 & 36,2 \\
\hline Morcone & 0 & 33,5 & Roccadaspide & 0 & 36,1 \\
\hline Sapri & 0 & 33,24 & Cava de' Tirreni & 0 & 36,1 \\
\hline San Bartolomeo In Galdo & 0 & 32,85 & Oliveto Citra & 0 & 35,8 \\
\hline Teano & 0 & 31,37 & San Bartolomeo In Galdo & 0 & 35,8 \\
\hline Forio & 0 & 31,31 & Sessa Aurunca & 0 & 35,7 \\
\hline Lacedonia & 0 & 31,01 & Sant'angelo Dei Lombardi & 0 & 35,6 \\
\hline Paternopoli & 1 & 30,7 & Postiglione & 0 & 35,4 \\
\hline Lauro & 0 & 30,55 & Napoli & 0 & 35,1 \\
\hline Vallata & 0 & 29,27 & Montecalvo Irpino & 0 & 35 \\
\hline Buccino & 1 & 28,68 & Calitri & 0 & 34,5 \\
\hline Apice & 1 & 27,8 & Paternopoli & 1 & 34,4 \\
\hline Piedimonte Matese & 0 & 27,63 & Futani & 0 & 34 \\
\hline Guardia Sanframondi & 0 & 27,42 & Castellammare Di Stabia & 0 & 33,6 \\
\hline San Marco Dei Cavoti & 1 & 26,82 & Aversa & 0 & 33,4 \\
\hline Futani & 0 & 26,75 & Vallata & 0 & 33,1 \\
\hline Circello & 0 & 26,69 & Torre Del Greco & 0 & 33 \\
\hline Postiglione & 0 & 26,46 & Ariano Irpino & 0 & 32,3 \\
\hline Roccadaspide & 0 & 25,83 & Lacedonia & 0 & 32,3 \\
\hline
\end{tabular}




\subsubsection{The role of Hides, Food and Tourism in Veneto}

\section{LEGEND}

Yellow $=$ Tourism, hotels and restaurants

Orange $=$ Hides and skins

Light blue $=$ Food, beverages and tobacco

\begin{tabular}{|c|c|c|c|c|c|}
\hline SLL & Distretti & VA/N 2005 & SLL & Distretti & Empl. Rate 2005 \\
\hline Venezia & 0 & 62,68 & San Giovanni Ilarione & 1 & 56,0 \\
\hline Rovigo & 0 & 59,07 & Thiene & 1 & 55,5 \\
\hline Belluno & 0 & 58,07 & Arzignano & 1 & 55,3 \\
\hline Verona & 0 & 57,65 & Grezzana & 1 & 54,9 \\
\hline Vicenza & 1 & 57,26 & Castelfranco Veneto & 1 & 54,8 \\
\hline Padova & 0 & 57,14 & Montebelluna & 1 & 54,1 \\
\hline Thiene & 1 & 54,84 & Pieve Di Soligo & 1 & 53,8 \\
\hline Cortina D'ampezzo & 0 & 54,26 & Treviso & 0 & 53,5 \\
\hline Pieve Di Cadore & 1 & 53,23 & San Bonifacio & 1 & 53,5 \\
\hline Treviso & 0 & 53,03 & Bassano Del Grappa & 1 & 53,5 \\
\hline San Bonifacio & 1 & 52,56 & Vicenza & 1 & 53,1 \\
\hline Arzignano & 1 & 52,37 & Schio & 1 & 52,7 \\
\hline Schio & 1 & 52,08 & Bovolone & 1 & 52,4 \\
\hline Agordo & 0 & 51,60 & San Donà Di Piave & 0 & 51,6 \\
\hline Porto Viro & 0 & 51,37 & Verona & 0 & 51,5 \\
\hline Grezzana & 1 & 51,34 & Conegliano & 1 & 51,5 \\
\hline San Donà Di Piave & 0 & 51,21 & Montagnana & 1 & 51,4 \\
\hline Feltre & 1 & 50,79 & Portogruaro & 1 & 51,3 \\
\hline Este & 1 & 50,08 & Legnago & 1 & 51,1 \\
\hline Bassano Del Grappa & 1 & 49,90 & Padova & 0 & 50,9 \\
\hline Castelfranco Veneto & 1 & 49,86 & Belluno & 0 & 50,6 \\
\hline Montagnana & 1 & 49,72 & Asiago & 0 & 50,5 \\
\hline Conegliano & 1 & 48,86 & Feltre & 1 & 49,8 \\
\hline Legnago & 1 & 48,64 & Malcesine & 0 & 49,7 \\
\hline Portogruaro & 1 & 47,67 & Pieve Di Cadore & 1 & 49,7 \\
\hline Pieve Di Soligo & 1 & 47,50 & Rovigo & 0 & 49,6 \\
\hline Auronzo Di Cadore & 1 & 46,92 & Este & 1 & 49,4 \\
\hline
\end{tabular}




\begin{tabular}{|l|l|l|l|l|l|}
\cline { 4 - 6 } Montebelluna & 1 & 45,76 & Badia Polesine & 1 & 48,4 \\
\hline Adria & 1 & 45,36 & Cortina D'ampezzo & 0 & 48,3 \\
\hline Bovolone & 1 & 44,36 & Auronzo Di Cadore & 1 & 48,2 \\
\cline { 5 - 7 } Asiago & 0 & 44,29 & Agordo & 0 & 48,2 \\
\hline Badia Polesine & 1 & 41,99 & Venezia & 0 & 47,9 \\
\hline Malcesine & 0 & 39,52 & Porto Viro & 0 & 46,6 \\
\hline San Giovanni llarione & 1 & 37,55 & Adria & 1 & 46,3 \\
\hline
\end{tabular}

